\title{
OPAIȚELE ROMANE DIN CASTRUL DE LA MICIA, PĂSTRATE ÎN COLECȚIILE MUZEULUI NAȚIONAL DE ISTORIE A ROMÂNIEI*
}

\author{
IONUȚ BOCAN, CĂTĂLINA-MiHAELA NEAGU
}

\section{ROMAN LAMPS DISCOVERED IN THE FORT AT MICIA, PRESERVED IN THE COLLECTION OF THE NATIONAL HISTORY MUSEUM OF ROMANIA}

This study focuses on the analyses of a specific type of archaeological material, namely the lamps, discovered in the Roman fort at Micia. These finds have a special place within the framework of archaeological discoveries due to the fact that the stamps or the other details offer the possibility to identify the workshop where the objects were manufactured, such element being relevant in establishing the relative chronology.

The analysis was made on a set of 111 pieces that had been discovered during the archaeological campaigns carried out between 1976 and 1987 in the Roman camp at Micia. The objects are now part of National History Museum of Romania collections. There are 110 lamps and an upper valve of a mould.

As regards the chronology of the lamps found in the fort at Micia, by considering the ones assigned by us as northern Italic imports, the manufacturers' workshops are functional during the $2^{\text {nd }} c$. AD. For the provincial and local product one has to consider the $2^{\text {nd }}-3^{\text {rd }} c$. AD, based on their archaeological contexts of provenance.

KEYWORDS: lamps, stamps, Roman fort, workshop, northern Italic imports, local products CUVINTE CHEIE: opaițe, ștampile, castru roman, atelier, importuri nord-italice, produse locale

\section{INTRODUCERE}

Situat pe malul stâng al râului Mureș, în imediata vecinătate a punctului cel mai îngust al văii Mureșului, loc ce se află în dreptul satului Brănișca, castrul roman de la Micia (com. Vețel, jud. Hunedoara) reprezenta elementul central de apărare al văii Mureșului în perioadă romană, controlând atât o importantă arteră de comunicație terestră cât și, probabil, una navală. Din punct de vedere militar, castrul are un rol dublu: pe de-o parte servea la apărarea graniței de vest a provinciei Dacia Superior, iar pe de altă parte bloca accesul în ținuturile miniere din Cadrilaterul Aurifer ${ }^{1}$. Edificiul militar a fost ridicat pe un platou natural cu o înălțime de aproximativ $3 \mathrm{~m}$, fiind orientat NV-SE. Astfel, protejat dinspre nord de râul Mureș, castrul de la Micia beneficia de o poziție strategică deosebită blocând intrarea dinspre vest în interiorul provinciei Dacia Superior ${ }^{2}$.

Deși a intrat destul de devreme în atenția cercetătorilor, în anul 1847 Johann Ferdinand Neigebaur executând două sondaje pe latura de nord ${ }^{3}$, primele cercetări sistematice au avut loc abia în anul 1929, fiind conduse de Constantin Daicoviciu. Cu această ocazie a fost cercetată tot latura de nord a castrului efectuându-se mai multe sondaje ${ }^{4}$. În anii 1967-1968, cu prilejul construirii termocentralei de la Mintia, Octavian Floca și Liviu Mărghitan au cercetat sistemul de fortificații de pe laturile de est și sud ale castrului ${ }^{5}$. Între anii 1976-1987 în castrul de la Micia au fost efectuate cercetări arheologice de către o echipă a Muzeului Național de Istorie a României

\footnotetext{
*Mulțumirile noastre se îndreaptă către domnul dr. Liviu Petculescu, coordonatorul cercetărilor arheologice efectuate în castrul de la Micia pentru amabilitatea de a ne pune la dispoziție atât materialul arheologic, cât și manuscrisul doamnei Ruxandra Anastasiu.

${ }^{1}$ Daicoviciu 1930-1931, 4.

${ }^{2}$ Daicoviciu 1930-1931, 5.

${ }^{3}$ Marinescu et alii 1979, 111.

${ }^{4}$ Daicoviciu 1930-1931, 1-43; Marinescu et alii 1979, 111.

${ }^{5}$ Floca, Mărghitan 1970, 43-57.
} 
(MNIR), coordonată de Liviu Petculescu. Au fost excavate și cercetate 26 de unităţi de săpătură, stabilindu-se dimensiunile exacte ale castrului: $360 \times 189,5 \mathrm{~m}^{6}(\mathbf{P l} . \mathbf{I} / \mathbf{1}-\mathbf{2})$.

Materialul arheologic descoperit în castrul de la Micia, deosebit de bogat și variat, alcătuit din ceramică, obiecte din metal, obiecte din piatră și obiecte din sticlă se află în colecțiile a trei muzee: Muzeul Național de Istorie a Transilvaniei, Cluj-Napoca (MNIT), Muzeul Civilizației Dacice și Romane, Deva (MCDR) și MNIR. În cadrul obiectelor din ceramică, opaițele ocupă un loc particular atât din punct de vedere artistic, cât și din punct de vedere al varietății morfologice. Muzeul din Deva este în posesia unei importante colecții de opaițe, valorificată de Cloșca Băluță prin publicarea unui articol în anul 1977. Între acestea se remarcă prin diversitatea tipologică un număr de 36 de exemplare provenite de la Micia, 12 exemplare fiind descoperite în urma cercetărilor arheologice efectuate în castru ${ }^{7}$. De asemenea, Cloșca Băluță este cel care a publicat în anul 1996 colecția de lămpi ștampilate aflată în posesia Muzeului din Cluj-Napoca. În cadrul acestui important lot de opaițe au fost descrise și analizate nouă exemplare provenite de la Micia, însă fără mențiuni referitoare la contextele arheologice ${ }^{8}$. Printre artefactele aflate în colecțiile MNIR se regăsește și un important lot de opaițe descoperite în castrul roman de la Micia. Acesta este constituit din 110 opaițe și valva superioară a unui tipar de lămpi. La începutul anilor '80 ai secolului trecut, Ruxandra Anastasiu a intenționat publicarea unui articol cu titlul Opaițele din castrul roman de la Micia (com. Vețel, jud. Hunedoara) în revista Acta Musei Napocensis. Acest studiu, în care erau analizate 38 de opaiţe și un tipar de lămpi, fragmentar, descoperite în castrul roman de la Micia între anii 1976-1979, nu a văzut niciodată lumina tiparului.

Studierea lămpilor descoperite în castrele romane din Dacia a progresat în ultimele două decenii. O serie de lucrări au abordat studiul opaiţelor descoperite în unele dintre centrele militare ale Daciei. Astfel, au fost publicate lămpile descoperite în castrele de la Porolissum, Buciumi, Gilău, Samum-Cășei ${ }^{9}$, Arcodabara-Ilișua ${ }^{10}$, Potaissa $^{11}$, Tibiscum $^{12}$, Gherla ${ }^{13}$, Jidava, Rucăr, Drajna de Sus ${ }^{14}$. În acest context se impunea atât valorificarea, cât și introducerea în circuitul științific a acestei importante colecții muzeale provenite din castrul de la Micia.

\section{TIPOLOGIA OPAIȚELOR}

Un aspect important al studierii instrumentelor de iluminat este reprezentat de analiza tipologică a acestora, criteriu consacrat în studierea ceramicii romane în general și al lămpilor în particular. Pentru încadrarea tipologică a lămpilor analizate în acest studiu, a fost utilizată tipologia de referință realizată de Sigfried Loeschcke pentru lămpile de la Vindonissa, în anul 1919. În cazul tipurilor de lămpi care nu se regăsesc în tipologia autorului mai sus menţionat, acestea au fost încadrate în tipologiile realizate de Dora Iványi, pentru lămpile din Pannonia, în anul 1935, respectiv Dorin Alicu pentru lămpile de la Ulpia Traiana Sarmizegetusa, în anul 1994.

Astfel, cele 110 piese analizate în acest studiu se pot încadra în șase tipuri de lămpi: Loeschcke IV (un exemplar), Loeschcke VIII (opt exemplare), Loeschcke IX (patru exemplare), Loeschcke X (52 de exemplare), Iványi IX (patru exemplare) și Alicu XI (un exemplar). Se impune menționat faptul că, în cazul a 24 de opaițe, cu o stare de fragmentaritate foarte ridicată nu s-a putut realiza o încadrare tipologică foarte clară în tipurile Loeschcke IX sau Loeschcke X, însă, se poate afirma cu certitudine că acestea fac parte din tipul cunoscut în literatura de specialitate sub

\footnotetext{
${ }^{6}$ Petculescu, Nemoianu, Anastasiu 1981, 70.

7 Băluță 1977, 218-223, 225, nr. cat. 14-16, 22, 25, 30, 33, 35-39, 45-49, 51, 54-55, 58-62, 65-69, 71-72, 74-77, 9394, pl. I/8, 11-12, II/20 a-b, III/23 a-b, IV/30-31, 34, 36 a-b, 37, V/49 a-b.

8 Băluță 1996, 101, 110, nr. cat. 43-50, 104, pl. I/7, II/7-9, VI/1, 4, 6-7, XIII/3, 6.

9 Isac, Roman 2001, 367-395; Roman 2006; Gudea, Cosma 2008, 117-128; Isac, Roman 2008, 153-154.

${ }^{10}$ Gaiu 2010, 217-244.

${ }^{11}$ Cătinaș 1996, 63-74.

${ }^{12}$ Benea 1990, 139-168.

${ }^{13}$ Protase, Gudea, Ardevan 2008, 107-111, pl. LXXXIII-LXXXVI.

${ }^{14}$ Negru 1996, 75-80.
} 
denumirea de Firmalampen. De asemenea, 16 lămpi nu au putut fi încadrate tipologic, din acestea păstrându-se fragmente de dimensiuni reduse și neconcludente din punct de vedere morfologic.

I. Lămpi cu volute, încadrabile în tipul Loeschcke IV

Acest tip de opaițe se individualizează prin ciocul rotunjit, încadrat de două volute, redate schematizat. Discul rotund, predominant concav, cu un orificiu de alimentare în centru este delimitat de bordură printr-un cordon circular. Bordură lată, decorată (motive geometrice și vegetale). Rezervor circular. Bază dreaptă sau concavă. Din punct de vedere cronologic acest tip este produs în Peninsula Italică pe parcursului secolului I p. Chr, circulând la nord de Alpi până în a doua jumătate a secolului al II-lea p. Chr. ${ }^{15}$ În Pannonia sunt menționate lămpi din acest tip asociate cu monede din timpul lui Nero, la Emona şi cu monede din timpul lui Vespasian ${ }^{16}$, la Poetovio. În Moesia Inferior, la Durostorum, acest tip este datat între mijlocul secolului I și a doua jumătate a secolului al II-lea p. Chr. ${ }^{17}$ În provinciile dacice acest tip de lămpi este rar întâlnit. Astfel de opaițe au fost descoperite la Tibiscum ${ }^{18}$ și la Gilău ${ }^{19}$. Piesele de la Tibiscum sunt datate în prima jumătatea secolului al II-lea, iar cea de la Gilău în a doua jumătate a secolului al II-lea.

În castrul de la Micia a fost descoperit un exemplar (nr. cat. 1), fragmentar, considerat de noi, un produs al atelierelor moesice (probabil Durostorum) ${ }^{20}$. Pe baza observațiilor stratigrafice și a celor mai apropiate analogii, acest opaiț este încadrat din punct de vedere cronologic la începutul secolului al II-lea p. Chr.

II. Lămpi cu cioc rotund și rezervor circular, încadrabile în tipul Loeschcke VIII

Lămpile din acest tip se caracterizează prin discul ușor concav, simplu sau ornamentat cu personaje mitologice, animale, rozete etc., delimitat de bordura îngustă printr-o incizie circulară sau un cordon. Ciocul scurt, rotunjit. Rezervor circular. Bază dreaptă sau ușor concavă. Majoritatea este prevăzută cu toartă, lamelară sau inelară. În castrul roman de la Micia au fost descoperite opt exemplare (nr. cat. 2-9). În funcție de modul de confecționare se pot distinge două variante:

II.a. Lămpi confecționate în tipar bivalv. Această variantă cuprinde patru piese fragmentare (nr. cat. 2-5). Două dintre acestea (nr. cat. 2-3) sunt produsele unor ateliere provinciale (Dacia Superior). În cadrul acestui tip se individualizează un opaiț polilychnis (nr. cat. 4). Deși piesa este fragmentară, în urma observațiilor întreprinse asupra pastei şi a modului de finisare poate fi atribuită unui atelier din nordul Peninsulei Italice. De asemenea, în urma aceluiași tip de analiză se remarcă faptul că lampa nr. cat. 5 este un import moesic (Moesia Inferior).

II.b. Lămpi confecționate la roata olarului, imitații ale tipului Loeschcke VIII. Această variantă este reprezentată prin patru exemplare (nr. cat. 6-9). În urma observațiilor întreprinse atât asupra pastei din care sunt confecționate, cât și asupra detaliilor stilistice și a modalității de confecționare, trei dintre piese (nr. cat. 6-7, 9) pot fi atribuite unor ateliere locale (Micia), în timp ce exemplarul nr. cat. 8 este atribuit unui atelier provincial (Dacia Superior). Nu excludem posibilitatea ca și acesta să fie produs în atelierele de la Micia.

Pe baza observațiilor stratigrafice coroborate cu cele mai apropiate analogii, cele opt lămpi (nr. cat. 2-9) pot fi încadrate din punct de vedere cronologic în secolul al II-lea p. Chr.

Un criteriu consacrat, utilizat pentru stabilirea originii atelierelor de producție este reprezentat de analiza stilistică a pieselor (motivele decorative de pe disc și bordură). Î́n cazul

\footnotetext{
${ }^{15}$ Loeschcke 1919, 37-38.

${ }^{16}$ Iványi 1935, 11.

${ }^{17}$ Mușețeanu, Elefterescu 1983, 113.

${ }^{18}$ Benea $1990,141,152$, nr. cat. 6-8, fig. $1 / 7$.

${ }^{19}$ Roman 2006, 37, 93, nr. cat. 38, pl. 17/38.

${ }^{20}$ Cea mai apropiată analogie o aflăm la Durostorum: Mușețeanu, Elefterescu 1983, 118, nr. cat. 9, fig. 9/a-b.
} 
opaițelor de tip Loeschcke VIII descoperite în castrul roman de la Micia, au fost identificate trei lămpi cu discul ornamentat (nr. cat. 3-5) și o lampă cu decor pe bordură (nr. cat. 8). Decorurile sunt simple putând fi clasificate în două tipuri: rozeta (decoruri pe disc) și rețea de incizii (decoruri pe bordură).

\section{Decoruri pe disc}

Decorul cu rozetă este întâlnit frecvent pe opaițele cu cioc scurt și rezervor circular încadrabile în tipul Loeschcke VIII. Astfel, dintre opaițele analizate în acest studiu se evidențiază trei exemplare de tipul Loeschcke VIII, modelate în tipare de bună calitate, având discul ornamentat cu rozetă (nr. cat. 3-5). Astfel de opaițe, cu rezervor circular, având ca ornament pe disc rozeta au fost descoperite în Dacia Superior, la Alburnus Maior ${ }^{21}$, Apulum $^{22}$, Tibiscum $^{23}$, Ulpia Traiana Sarmizegetusa ${ }^{24}$, în Dacia Porolissensis, în castrele de la Buciumi ${ }^{25}$, Gilău ${ }^{26}$, Samum ${ }^{27}$ și Porolissum $^{28}$, iar în Dacia Inferior, la Orlea ${ }^{29}$, Slăveni ${ }^{30}$ și Sucidava ${ }^{31}$. Piese asemănătoare din punct de vedere al ornamentației de pe disc au fost descoperite pe cuprinsul întregului Imperiu. Amintim astfel, descoperirea unor lămpi cu decor asemănător în Moesia Inferior, la Kavala ${ }^{32}$, Pazardjik ${ }^{33}$, Peștera-La Adam ${ }^{34}$, Poșta $^{35}$, Sâmbăta Nouă ${ }^{36}$, Serdica $^{37}$, Tomis $^{38}$, Varna ${ }^{39}$, Vidin $^{40}$. De asemenea, astfel de opaițe au fost descoperite în Africa, la Tebessa ${ }^{41}$ în Asia, la Pergam ${ }^{42}$, în Hispania Tarraconensis, la Tarragona ${ }^{43}$, în Mauretania Tingitana la Ceuta ${ }^{44}$.

\section{Decoruri pe bordură}

Din lotul de opaițe de tip Loeschcke VIII analizat în acest studiu un singur exemplar are bordura decorată cu rețea de incizii (nr. cat. 8). Cea mai apropiată analogie a acestei piese o aflăm la Ulpia Traiana Sarmizegetusa ${ }^{45}$. Astfel, opaițe de acest tip, cu bordura decorată cu rețea de incizii au fost descoperite în Dacia Superior, la Apulum ${ }^{46}$ și la Tibiscum ${ }^{47}$ și în Dacia Porolissensis, la Gilău ${ }^{48}$.

\footnotetext{
${ }^{21}$ Piese inedite aflate în colecțiile MNIR.

${ }^{22}$ Băluță 1965, 281-282, pl. I/3, 7, 10, 14, pl. II/1-3, 7; Lychnus et Lampas 2006, 70, nr. cat. 186, fig. 186 (voce Adriana Isac).

${ }^{23}$ Benea 1990, 155, nr. cat. 16, fig. 3/16.

${ }^{24}$ Băluță 1977, 219, nr. cat. 18; Alicu 2006, 100, Kat. 383-384, Taf. VI/384, 102, Kat. 392; Lychnus et Lampas 2006, 69, nr. cat. 177, fig. 177 (voce Adriana Isac).

${ }^{25}$ Chirilă et alii 1972, 55, nr. cat. 23, pl. XLIV/4; Roman 2006, 105, nr. cat. 69.

${ }^{26}$ Isac, Roman 2001, 370, nr. cat. 8-10, pl. II/8-10; Roman 2006, 103-105, nr. cat. 66-68, pl. 12/66-68, 18/66-67, 69.

${ }^{27}$ Roman 2006, 99-100, nr. cat. 55, pl. 12/55, 18/55.

${ }^{28}$ Roman 2006, 100, nr. cat. 57, pl. 8/57, 12/57; Matei et alii 2006, 86, nr. cat. 123, fig. 123, 87, nr. cat. 126, fig. 126.

${ }^{29}$ Gherghe, Cojoc 2011, 62-63, nr. cat. 11-13, pl. 43/11, pl. 3/12-13.

${ }^{30}$ Lychnus et Lampas 2006, 68, nr. cat. 171, fig. 171 (voce Dorel Bondoc).

${ }^{31}$ Gherghe, Cojoc 2011, 61-62, nr. cat. 8-10, pl. 1/8, 2/9-10.

${ }^{32}$ Kuzmanov 1992, 27, nr. cat. 159, fig. 159.

${ }^{33}$ Kuzmanov 1992, 31, nr. cat. 200, fig. 200.

${ }^{34}$ Iconomu 1967, 108, nr. cat. 539.

${ }^{35}$ Paraschiv, Nuțu 2012, 289, nr. cat. 7, pl. 3/7.

${ }^{36}$ Iconomu 1967, 107, nr. cat. 537-538.

${ }^{37}$ Kuzmanov 1992, 31, nr. cat. 201, fig. 201

${ }^{38}$ Iconomu 1967,64 , nr. cat. 195 , fig. 29,65 , nr. cat. 202, 204, 206, 68-69, nr. cat. 227, fig. 101, 106-107, nr. cat. 529536, fig. 128, 108-109, nr. cat. 540-550, fig. 131.

${ }^{39}$ Kuzmanov 1992, 26, nr. cat. 140-141, fig. 140-141.

${ }^{40}$ Kuzmanov 1992, 27, nr. cat. 146, fig. 146, 29, nr. cat. 178, fig. 178.

${ }^{41}$ Bussière 2000, 285, nr. cat. 1085, pl. 52/1085.

${ }^{42}$ Heimerl 2001, 128, nr. cat. 371, pl. 9/371.

${ }^{43}$ Rodriguez Martin 2005, 110-111, nr. cat. 43, fig. 43.

${ }^{44}$ Casasola 1995, 61, nr. cat. 27, fig. 27.

${ }^{45}$ Alicu 2006, 99, Kat. 379, Taf. VI/379.

${ }^{46}$ Băluță 1983, 7, pl. IX/10.

${ }^{47}$ Benea 2012, 27, Taf. IV/21.

${ }^{48}$ Roman 2006, 101, nr. cat. 59, pl. 18/59.
} 
III. Lămpi dreptunghiulare, încadrabile în tipul Iványi IX

Acest tip de lămpi se caracterizează prin suprafața superioară dreptunghiulară, plană, în unele cazuri împărțită în două registre delimitate printr-un cordon, de multe ori redat sub forma unui șnur. Fiecare registru este prevăzut cu un orificiu de alimentare. Cioc scurt, prevăzut cu un număr variabil de orificii de ardere de la două la nouă. Rezervor paralelipipedic. Bază dreaptă. Majoritatea sunt prevăzute cu ansă, aceasta reprezentând una dintre cele mai interesante părți componente din punct de vedere al ornamentației. În ceea ce privește locul de origine al acestui tip de opaițe este unanim acceptat faptul că acestea au apărut în provincia romană Egipt, cel mai probabil la Fayum ${ }^{49}$, la sfârșitul secolului al II-lea a $\mathrm{Chr}^{50}$, formele timpurii având probabil ciocurile separate. Inițial, unele exemplare erau prevăzute cu arzătoare și pe părțile laterale ${ }^{51}$. Asemenea opaiţe au fost descoperite la Herakleopolis Magna (Ehnasya) în Egipt, acestea fiind, probabil confecționate la Fayum ${ }^{52}$. Patru exemplare au ajuns, între timp, în colecțiile Royal Ontario Museum, fiind publicate detaliat de Jhon W. Heyes în anul $1980^{53}$. O astfel de lampă se află în colecțiile Römisch-Germanisches Zentralmuseum, Mainz, fiind descoperită la Abu Mena, în Egipt $^{54}$. De asemenea, un număr de șase exemplare aparţinând acestui tip de opaițe, ce provin tot din Egipt, se află în colecțiile British Museum ${ }^{55}$. În urma analizei acestor piese, Donald M. Bailey sugerează că acest tip de lămpi derivă din opaițele elenistice târzii ${ }^{56}$. Evoluția tipologică a acestor piese poate fi observată analizând caracteristicile morfologice și stilistice ale unor opaițe descoperite la Delos. Este vorba despre două subtipuri de lămpi definite de Philippe Bruneau ca lămpi decorate cu rozete și opaițe syrinx, ambele făcând parte din tipul opaițe cu ciocuri dispuse în linie $^{57}$.

Acest tip de opaiț nu este foarte răspândit, iar în provinciile în care apare se poate observa o puternică influență locală, nu atât din punct de vedere morfologic, cât mai degrabă din punct de vedere stilistic (motivele decorative prezente pe toartă și pe suprafața superioară). În Dacia Superior este întâlnit la Apulum ${ }^{58}$, Cristești ${ }^{59}{ }^{\text {Drobeta }}{ }^{60}$, Micăsasa ${ }^{61}$, Micia $^{62}$, Tibiscum $^{63}$, Turdaș ${ }^{64}$, Ulpia Traiana Sarmizegetusa ${ }^{65}$. În Dacia Porolissensis piesele își găsesc analogii la Cășei ${ }^{66}$, Napoca $^{67}$, Porolissum ${ }^{68}$, Potaissa ${ }^{69}$. În Dacia Inferior lămpi încadrabile în acest tip au fost descoperite în zona Sucidavei ${ }^{70}$ și la Orlea ${ }^{71}$.

\footnotetext{
${ }^{49}$ Bailey 1988, 220-221.

${ }^{50}$ Krunić 2005, 67; Regep-Vlascici, Muscalu 2007, 159; Chrzanovski 2011, 218.

${ }^{51}$ Krunić 2005, 67.

${ }^{52}$ Petrie 1905, 7, pl. LVII/50, 52, 54, 56, 60, 62, 64, 70, 72. W. M. Flinders Petrie le încadrează în tipul M, lămpi multiple.

${ }^{53}$ Hayes 1980, 39-40, nr. cat. 186-189, pl. 19/186-189.

${ }^{54}$ Menzel 1954, 73, Kat. 488, Abb. 56/9.

${ }^{55}$ Walters 1914, 65-66, nr. cat. 446-447, fig. 70, pl. XV/446. Bailey 1988, 241, nr. cat. Q 1971 EA - 1972 EA, Q $1973-$ Q 1975, Q 1976 EA, pl. 37/ Q 1971 EA - 1972 EA, Q 1973 - Q 1975, Q 1976.

${ }^{56}$ Bailey 1988, 220.

${ }^{57}$ Bruneau 1965, 103-106, nr. cat. 4450, 4453, 4516-4524, pl. 26/4450, 4453, 4454, pl. 27/4516, 4518, 4519-4522, 4524.

${ }^{58}$ Băluță 1965, 6, pl. II/5-6.

${ }^{59}$ Man 2011, 178, 185-186, nr. cat. 37-40, pl. CXXIX/37-39, CXXX/40; Lychnus et Lampas 2006, 82, nr. cat. 263, 135, fig. 263 (voce Nicoleta Man).

${ }^{60}$ Lychnus et Lampas 2006, 77, nr. cat 229, 130, fig. 229 (voce Răzvan Cristian Rus și Mihai Stângă).

${ }^{61}$ Lychnus et Lampas 2006, 59, nr. cat 117-118, 112-113, fig. 117-118 (voce Adriana Isac).

${ }^{62}$ Băluță 1977, 219, nr. cat. 15-16, pl. I/11-12; Alicu 2006, 42, nota 327. Piesele fac parte din colecțiile MCDR.

${ }^{63}$ Benea 1990, 143, 157, nr. cat. 27-30, fig. 3/28, 29, fig. 4/30, fig. 13/27; Regep-Vlascici, Muscalu 2007, 159-170.

${ }^{64}$ Băluță 1996, 94, nr. cat. 11, pl. VII/4, XIII/15.

65 Alicu 2006, 41-44, 74-96, Kat. 53-366; Lychnus et Lampas 2006, 58-59, 74-77, nr. cat. 113-116; 214; 221-222; 227-228; 230-232, fig. 113-116; 214; 221-222; 227-228; 230-232 (voce Adriana Isac).

${ }^{66}$ Roman 2006, 31, 92, nr. cat. 34, pl. 16/34.

${ }^{67}$ Roman 2005, 148, 227, nr. cat. 53, pl. 65/53, 66/53; Alicu 2006, 42, nota 327. Piesele fac parte din colecțiile MNIT.

${ }^{68}$ Roman 2006, 31, 92-93, nr. cat. 33; 35-37, pl. 13/33, 16/33; 35; 37; Matei et alii 2006, 94, nr. cat. 147-148, fig. 147-148.

69 Bărbulescu, Cătinaș 1992, 112, fig. 5/2; Cătinaș 1997, 179-180, pl. 6/1 a-b, 6/2, una dintre piese a făcut parte din colecția Téglás, iar cealaltă din colecția Fekete Ferencz.

${ }^{70}$ Gherghe, Cojoc 2011, 39, pl. 8/39.

${ }^{71}$ Gherghe, Cojoc 2011, 39, pl. 45/40.
} 
Asemenea opaițe erau produse și în spațiile învecinate provinciilor dacice: în Pannonia au fost descoperite la Intercisa, Poetovio, Aquincum, Ószőny, Szombathely ${ }^{72}$. Piesele descoperite în Pannonia sunt total diferite la nivelul ornamentației de cele descoperite în provinciile dacice. În ceea ce privește datarea, puținele repere cronologice le încadrează între secolele II-IV p. Chr. La Singidunum, în Moesia Superior, au fost descoperite opaițe aparținând acestui tip ${ }^{73}$, datate în secolele II-III p. Chr. ${ }^{74}$ De la Carnuntum, în provincia Noricum, provin trei exemplare încadrabile în acest tip ${ }^{75}$.

In castrul roman de la Micia au fost descoperite patru exemplare (nr. cat. 10-13). Dintre acestea, doar unul este întreg (nr. cat. 10), restul fiind fragmentare și oferind așadar foarte puține elemente care să determine o analiză detaliată. Tot de la Micia provin alte două opaițe dreptunghiulare fără context arheologic clar. Acestea fac parte din colecțiile MCDR, fiind publicate de către Cloșca Băluță în anul $1977^{76}$. Cea mai apropiată analogie a acestui tip de opaiț o aflăm la Ulpia Traiana Sarmizegetusa ${ }^{77}$. În urma observațiilor întreprinse asupra pastei din care sunt confecționate și asupra detaliilor stilistice, coroborate cu cele mai apropiate analogii se poate afirma faptul că aceste opaițe sunt confecționate într-un atelier provincial, cel mai probabil la Ulpia Traiana Sarmizegetusa, unde exista un atelier, probabil al lui Ianuarivs, care producea asemenea opaițe, încă din prima jumătate a secolului al II-lea p. $\mathrm{Chr}^{78}$. Descoperirea la Feldioara a valvei inferioare a unui tipar în care erau confecționate opaițe cu cinci orificii de ardere, încadrate în acest tip, poate sugera existența unui alt atelier, care confecționa asemenea lămpi ${ }^{79}$. Din punct de vedere cronologic cele patru exemplare de la Micia se datează în secolul al II-lea p. Chr.

\section{Opaiţe de tip Firmalampen}

Termenul de origine germană Firmalampen (utilizat pentru prima oară în anul 1896 de către Otto Fischbach ${ }^{80}$ datorită faptului că de cele mai multe ori opaițele aveau marcat numele producătorului pe bază) este folosit pentru a defini o categorie de lămpi cu o formă mult simplificată, dar în același timp elaborată. De-a lungul timpului, acestea au fost divizate în numeroase subtipuri ${ }^{81}$. Cronologia acestui tip de opaițe suscită încă numeroase discuții, în special cu privire la începuturile producției primelor exemplare și la răspândirea acestora din Peninsula Italică în aproape toate provinciile Imperiului Roman. Apariția opaițelor de tip Firmalampen este plasată între primele decenii ale secolului I a. Chr și primul sfert al secolului I p. Chr. ${ }^{82}$ Producția acestui tip de lămpi atinge apogeul pe parcursul secolului al II-lea p. Chr., continuând să circule până în secolul al IV-lea p. Chr.

\section{IV.1. Lămpi cu canal închis, tipul Loeschcke IX}

Opaițele din acest tip au discul rotund, concav, deseori ornamentat, delimitat de bordură printr-un cordon proeminent. Bordura este prevăzută cu butoni dispuşi aproximativ simetric. Ciocul alungit, rotunjit, prevăzut cu un orificiu de ardere este străbătut longitudinal de un canal, adesea prevăzut cu un mic orificiu de ventilație, forma canalului fiind cea care diferențiază variantele

\footnotetext{
${ }^{72}$ Iványi 1935, 13, 94-96, nr. cat. 820-855, pl. XXXII/1-9, XXXIII/1-11.

${ }^{73}$ Krunić 2005, 66, nr. cat. 32-33.

${ }^{74}$ Krunić 2005, 67.

75 Alram-Stern 1989, 273-274, nr. cat. 555-557, pl. 37/555-557.

${ }^{76}$ Băluță 1977, 219, nr. cat. 11-12, pl. I/11-12.

77 Lychnus et Lampas 2006, 74, nr. cat. 214, 128, fig. 214 (voce Adriana Isac); Chrzanovski 2011, 223, fig. 10, un exemplar identic cu nr. cat. 9 de la Micia.

78 Alicu 1994, 46-48.

${ }^{79}$ Lychnus et Lampas 2006, 53, nr. cat. 80, fig. 80 (voce Nicoleta Man).

${ }^{80}$ Loeschcke 1919, 255.

${ }^{81}$ Loeschcke 1919, 255-298; Iványi 1935, 15-19; Menzel 1954, 60-71; Buchi 1975, XXIII-XXVIII; Leibundgut 1977, 41-49; Băluță 2003, XII-XV; Alicu 2006, 47-54.

${ }^{82}$ Leibundgut 1977, 42; Chrzanovski, Zhuravlev 1998, 72; Chrzanovski 2000, 52.
} 
acestui tip. Se diferențiază astfel trei variante: opaițe cu canal închis la ambele extremităti (în forma literei „I"), opaițe cu canal în formă de jgheab, închis la extremități și opaițe cu canal în forma literei „V”, canalul fiind deschis spre disc. Rezervor tronconic. Baza dreaptă sau ușor concavă, delimitată de unul sau mai multe cercuri concentrice, incizate, caneluri fine sau profilaturi în unele cazuri, are înscrisă în centru ștampila producătorului. Uneori sunt prevăzute cu ansă inelară sau lamelară.

În castrul roman de la Micia au fost descoperite patru exemplare (nr. cat. 14-17) încadrabile în acest tip. În urma analizei detaliate a acestora se disting două variante. O primă variantă reprezentată prin trei piese (nr. cat. 14-16), care se înscriu, în linii mari în descrierea generală a tipului, individualizându-se însă, prin discul decorat cu rozetă, probabil cu opt lobi, motiv cunoscut în Dacia Superior pe acelaşi tip de opaițe la Apulum ${ }^{83}$ şi la Ulpia Traiana Sarmizegetusa $^{84}$, iar în Dacia Porolissensis la Porolissum ${ }^{85}$. De asemenea, se impune menționat faptul că un exemplar (nr. cat. 14), poartă pe bază ștampila atelierului în care a fost produs, ATIMETI. O lampă asemănătoare, cu ștampila ATIMETI, descoperită la Apulum-Viile Episcopiei este considerată de Cloșca Băluță de proveniență autohtonă (produsă la Apulum) ${ }^{86}$. Un alt opait asemănător, tot cu ștampila ATIMETI a fost descoperit la Porolissum ${ }^{87}$. De asemenea, cele trei piese încadrate de noi în această variantă își găsesc cea mai apropiată analogie la Apulum $^{88}$. În urma observațiilor întreprinse asupra detaliilor stilistice, coroborate cu cele mai apropiate analogii aceste opaițe sunt confecționate într-un atelier provincial, cel mai probabil la Apulum. Nu excludem posibilitatea ca aceste piese să fi fost confecționate la Micia, însă în lipsa unor analize fizicochimice nu se poate afirma cu certitudine acest fapt.

Cea de-a doua variantă este reprezentată de o singură piesă (nr. cat. 17), care se diferențiază de celelalte prin canalul mult mai lat, prin cei doi butoni amplasaţi între cordon și canal și prin bordura mai bombată. $\mathrm{Nu}$ au fost găsite analogii pentru această lampă, argumentul care ne-a determinat să o încadrăm în acest tip fiind reprezentat de canalul dintre orificiul de ardere și disc (închis doar spre disc). Acest argument ne determină să atribuim piesa în discuție unui atelier din așezarea de la Micia.

Forma, pasta, modalitatea de confecționare a pieselor, ștampila atelierelor în care sunt produse (în cazul nr. cat. 14), cât și principalele analogii reprezintă argumente care ne îndreptățesc să datăm opaițele încadrate în acest tip în secolul al II-lea p. Chr.

\section{IV.2. Lămpi cu canal deschis, tipul Loeschcke X}

Acest tip de lămpi se caracterizează prin discul neted sau ușor concav, de formă rotundă, uneori ornamentat, prevăzut cu un orificiu de alimentare, delimitat de bordură printr-un cordon proeminent, care se îndreaptă spre cioc, îl înconjoară și formează un canal prevăzut deseori cu un mic orificiu de ventilație. Bordura, îngustă sau lată, în unele cazuri cu doi sau trei butoni este decorată cu incizii dispuse radial, rețele de incizii, ove, ghirlande etc. Ciocul, cu un arzător sau mai multe, este alungit, rotunjit, uneori în formă de vârf de săgeată arondat. Partea inferioară a ciocului este uşor arcuită spre extremitate, iar rezervorul tronconic. Baza dreaptă sau ușor concavă, delimitată de unul sau mai multe cercuri concentrice incizate, caneluri fine sau profilaturi, adeseori are înscrisă în centru ștampila atelierului în care sunt produse piesele.

Este cel mai frecvent tip de lămpi întâlnit în castrul roman de la Micia, unde au fost descoperite 52 de exemplare (nr. cat. 18-69), întregi sau fragmentare. Așa cum am menționat anterior, din castrul roman de la Micia provin 24 de opaițe (nr. cat. 70-93) a căror stare precară de conservare nu ne-a permis o încadrare tipologică pe baza elementului consacrat, utilizat cel mai frecvent în realizarea tipologiilor (ciocul). Cu toate acestea, celelalte elemente morfologice păstrate

\footnotetext{
${ }^{83}$ Băluță 2003, 16, nr. cat. VIII/2.

${ }^{84}$ Alicu 2006, 106, Kat. 417, Taf. VII/417.

${ }^{85}$ Matei et alii 2006, 84, nr. cat. 119, fig. 119.

${ }^{86}$ Băluță 2003, 15-16.

${ }^{87}$ Matei et alii 2006, 84, nr. cat. 119, fig. 119.

${ }^{88}$ Băluță 2003, 15-16.
} 
oferă indicii pentru încadrarea pieselor în discuție, în ceea ce este denumit generic, în literatura de specialitate drept Firmalampen, fără a putea realiza o distincție clară între tipurile IX și X din tipologia lui Sigfried Loeschcke.

\section{DECORURI}

\section{a. Decoruri pe bordură}

Una dintre modalităţile de a diferenția opaițele de origine nord-italică de cele produse în atelierele locale sau provinciale este reprezentată de analiza stilistică (motivele ornamentale de pe bordură și disc). Astfel, fără a modifica aspectul morfologic al opaițelor meșterii locali din provinciile dacice au îmbogățit repertoriul clasic al decorurilor. În castrul roman de la Micia au fost descoperite șapte opaițe cu bordura ornamentată (nr. cat 19, 31, 37, 40, 54, 68, 85, ). Decorurile sunt simple putând fi clasificate în trei tipuri: incizii dispuse radial, rețea de incizii, și o combinație de rețea de incizii cu incizii dispuse radial.

\section{a.1. Incizii dispuse radial}

Printre opaițele descoperite în castrul roman de la Micia, aflate în colecțiile Muzeului Național de Istorie a României se găsesc și două opaiţe ornamentate cu incizii radiale pe bordură (nr. cat. 40 și nr. cat. 68), realizate în tipar. O altă piesă având bordura decorată cu incizii radiale, provine tot de la Micia, dar fără context arheologic clar. Aceasta se află în colecțiile $\mathrm{MNIT}^{89}$. De asemenea, alte două opaițe provenite de la Micia (prima descoperită într-una dintre necropolele de la Micia, iar cea de-a doua în castru) au bordura decorată cu incizii radiale. Piesele se află în colecțiile $\mathrm{MCDR}^{90}$. Opaițe cu bordura decorată cu incizii radiale au fost descoperite la Alburnus Maior $^{91}$, Ampelum ${ }^{92}$, Apulum ${ }^{93}$, Cinciș ${ }^{94}$, Drajna de Sus ${ }^{95}$, Miercurea Sibiului ${ }^{96}$, Potaissa ${ }^{97}$, Sintamaria de Piatră ${ }^{98}$. În urma consultării unei vaste bibliografii, se poate afirma faptul că acest decor, asociat cu opaițele de tip Firmalampen este unul specific provinciilor dacice și panonice. De exemplu, de la Aquincum provine un opaiț de tipul Loeschcke IX, decorat pe bordură cu incizii radiale $^{99}$.

\section{a.2. Retea de incizii}

Din lotul de opaițe de tip Firmalampen analizat în acest studiu două exemplare au bordura decorată cu rețea de incizii (nr. cat. 31, respectiv nr. cat. 37). Trebuie menționat faptul că piesa nr. cat. 31 are imprimată pe bază ştampila atelierului în care a fost confecționată, IA[NVARI]. Un alt opaiț având bordura decorată cu rețea de incizii, provenit tot de la Micia, dar fără context arheologic clar, se află în colecțiile MNIT $^{100}$. Astfel, se poate afirma că acest decor este unul specific provinciei Dacia Superior. Argumentația se bazează pe faptul că acest motiv nu este

\footnotetext{
89 Băluță 1996, 101, nr. cat. 46, pl. VI/7.

90 Băluță 1977, 221, nr. cat. 39, 222, nr. cat. 61.

91 Simion, Apostol, Vleja 2004, 65, nr. cat. 46, pl. 42/46; Alburnus Maior III, 84, nr. cat. 4, pl. 25/4, 95, nr. cat. 2, pl. 42/2, 96, nr. cat. 6, pl. 45/6, 102, nr. cat. 6, pl. 51/6, 110, nr. cat. 3, pl. 68/3, 114, nr. cat. 9, pl. 72/9, 162, nr. cat. 2 , pl. $146 / 2$, 168, nr. cat. 2 , pl. 158/2, 221, nr. cat. 4, pl. 279/4, 239, nr. cat. 54, pl. 320/54.

92 Lipovan 1982-1983, 228, nr. cat. 4, pl. II/1.

93 Băluță 2003, 76, nr. cat. XXXII/1, fig. XXXII/1, 84. nr. cat. XXXII/69, fig. XXXII/69, 111, nr. cat. XL/5, pl. XL/5.

94 Floca, Valea 1965, 177, fig. 11/4; Băluță 1977, 221, nr. cat. 42, pl. III/25.

95 Topoleanu 2010, 176, nr. cat. 8, pl. II/8.

96 Băluță 1996, 109-110, nr. cat. 96, pl. X/2.

97 Băluță 1996, 110, nr. cat. 101, pl. II/4; Cătinaș 1996, 68, nr. cat. 13, fig. 3/13; Cătinaș 1997, 184, fig. 9/2.

98 Băluță 1977, 219, nr. cat. 19, pl. II/15.

99 Iványi 1935, 134, nr. cat. 1449, pl. XLVIII/2.

${ }^{100}$ Băluță 1996, 101, nr. cat. 49, pl. II/9, XIII/3.
} 
documentat în restul Imperiului. Opaițe cu bordura decorată cu rețea de incizii au fost descoperite la Abrud ${ }^{101}$, Alburnus Maior ${ }^{102}$, Apulum ${ }^{103}$, Corpadea ${ }^{104}$, Napoca ${ }^{105}$, Potaissa ${ }^{106}$, Ulpia Traiana Sarmizegetusa ${ }^{107}$. Se poate postula ideea conform căreia, lămpile care au bordura decorată cu rețea de incizii reprezintă produsele unor ateliere provinciale (Dacia Superior).

\section{a.3. Rețea de incizii și incizii dispuse radial}

Din castrul roman de la Micia provin două opaițe cu bordura ornamentată atât cu rețea de incizii, cât și cu linii incizate, dispuse radial (nr. cat. 54 și nr. cat. 85). Acest tip de decor are o frecvență redusă, fiind, probabil specific provinciilor dacice. Consultând o bibliografie vastă se poate observa că acest tip de ornamentație nu este utilizat în alte provincii ale Imperiului Roman. De asemenea, se impune menționat faptul că un astfel de opaiț, cu bordura decorată atât cu rețea de incizii, cât și cu incizii radiale spre cioc, aflat în colecția particulară Vince Wartha, dar având locul de proveniență necunoscut, a fost publicat de către Tihamér Szentléleky ${ }^{108}$ în anul 1969. Nu excludem însă posibilitatea ca acest exemplar să fi fost descoperit în Transilvania. Astfel, opaițe cu bordura decorată cu rețea de incizii și linii incizate dispuse radial au fost descoperite la Alburnus Maior $^{109}$, Apulum ${ }^{110}$, Porolissum ${ }^{111}$.

\section{b. Decoruri pe disc}

\section{b.1 Rozete}

Acest tip de decor apare frecvent pe opaiţele încadrabile în tipul Loeschcke VIII şi cu o frecvență redusă pe opaițele de tip Firmalampen. Astfel, printre opaițele descoperite în castrul roman de la Micia aflate în colecțiile Muzeului Național de Istorie a României se evidenţiază patru exemplare de tip Firmalampen, cu disc ornamentat cu rozetă (nr. cat. 14-16, 19). Din punct de vedere al elementelor morfologice trei opaițe se încadrează în tipul Loeschcke IX (nr. cat. 14-16), iar cel de-al patrulea în tipul Loeschcke X (nr. cat. 19). Pe baza bibliografiei consultate, se poate constata că asocierea acestui decor cu opaițele de tip Firmalampen este specifică provinciilor dacice. Astfel, putem postula ipoteza conform căreia aceste opaițe de tip Firmalampen cu disc ornamentat cu rozetă nu sunt cunoscute în restul Imperiului. Pentru exemplarele încadrabile în tipul Loeschcke IX (nr. cat. 14-16) nu am găsit analogii decât la Apulum ${ }^{112}$ și Porolissum ${ }^{113}$, unde au fost descoperite piese asemănătoare cu opaițele noastre. Se impune menționat faptul că două dintre aceste opaițe (nr. cat. 14, nr. cat. 19) au imprimată pe bază ștampila atelierului în care au fost confecționate, ATIMETI. De asemenea, lămpile de la Apulum și Porolissum sunt marcate cu aceeași ștampilă. Așadar, nu excludem posibilitatea ca cele trei opaițe descoperite la Micia (nr. cat.

${ }^{101}$ Băluță 1989, 251, nr. cat. 42, pl. III/7.

${ }^{102}$ Moga et alii 2003, 243, fig. 29/8; Simion, Apostol, Vleja, 2004, 66, nr. cat. 50, pl. 42/50; Simion et alii 2007-2008, 141, nr. cat. 36, pl. X/36; Alburnus Maior III, 89, nr. cat. 1, pl. 33/1, 106, nr. cat. 9, pl. 58/9, 107, nr. cat. 2, pl. 61/2, 109 , nr. cat. 16, pl. 65/16, 113, nr. cat 1, pl. 70/1, 133, nr. cat. 4, pl. 99/4, 136, nr. cat. 1, pl. 103/1, 140, nr. cat. 3 , pl. $110 / 3$, 147, nr. cat. 1 , pl. 120/1, 150, nr. cat. 1, pl. 124/1, 154, nr. cat. 2, pl. 130/2, 214, nr. cat. 7, pl. 262/7, 217, nr. cat. 7, pl. 268/7; Bocan, Ursuțiu, Cociş 2007-2008, 210-211, nr. cat. 16, 32, pl. 3/16, 4/32; Simion et alii 2007-2008, 141, nr. cat. 46, nr. cat. 36, pl. X/36; Bocan, Ursutiu, Cocis 2008, 47-48, nr. cat. 16, 32, pl. 13/16, 15/32.

103 Băluță 1961, 199, nr. cat. 13, pl. IV/5, XI/7; Băluță 1989, 247, nr. cat. 32, pl. VI/8, 255, nr. cat. 64, pl. VII/5; Băluță 2003, 55, nr. cat. 20, fig. 20,79, nr. cat. 25, pl. 25 (Cloșca Băluță consideră piesa publicată la pagina 55, nr. cat. 20, import italic, probabil datorită decorului de pe disc); Egri 2005, 85, pl. 35, fig. $2 / 2$.

${ }^{104}$ Băluță 1996, 110, pl. IX/2.

${ }^{105}$ Mitrofan 1964, 201-202, fig. 3/2.

${ }^{106}$ Băluță 1989, 251, nr. cat. 48, pl. VI/1; Cătinaș 1997, 176, fig. 2/1.

107 Alicu 2006, 130, Kat. 547, Taf. XIII/547.

${ }^{108}$ Szentléleky 1969, 91, nr. cat. 136, fig. 136 a (în colecția Szépművészeti Múzeum).

${ }^{109}$ Alburnus Maior III, 117, nr. cat. 1, pl. 78/1, 124, nr. cat. 6, pl. 87/6, 137, nr. cat. 2, pl. 105/2, 143-144, nr. cat. 1, pl. $117 / 1,166$, nr. cat. 4 , pl. 154/4, 176, nr. cat. 4, pl.173/4.

${ }^{110}$ Băluță 1989, 251, nr. cat. 43, pl. VI/8; Băluță 2003, 82, nr. cat. XXXII/45, pl. XXXII/45.

${ }^{111}$ Roman 2006, 125-126, nr. cat. 130, pl. 21/130.

112 Băluță 2003, 15-16, nr. cat. VIII/2, fig. VIII/2.

${ }^{113}$ Matei et alii 2006, 84, nr. cat. 119, fig. 119. 
14-16) și cele două piese de la Apulum, respectiv Porolissum să fi fost confecționate în același atelier, cu certitudine, unul provincial. Tot la Apulum este atestată o lampă de tipul Loeschcke IX, cu discul decorat cu rozetă și ștampila ATIMETI pe bază. Piesa în discuție este un opait trilychnis $^{114}$. Un opaiț asemănător, purtând ștampila mai sus menționată, dar bilychnis a fost descoperit la Napoca ${ }^{115}$. Nu putem încheia făă a menționa un alt opaiț trilychnis, de tipul Loeschcke IX, cu rozetă pe disc, dar purtând ștampila FORTIS, descoperit la Apulum ${ }^{116}$.

Piese cu rozetă pe disc, asemănătoare cu opaițul încadrat în tipul Loeschcke X (nr. cat. 19) au fost descoperite doar la Apulum. Sunt opaițe bilychnis sau trilychnis, purtând pe bază ștampilele: AQVILA $^{117}$, ATIMETI ${ }^{118}$, CASSI $^{119}$, CAI GEMELLINVS ${ }^{120}$ și STROBILI ${ }^{121}$. Un alt opaiț bilychnis, încadrat în același tip, Loeschcke X, cu disc decorat cu rozetă și având pe bază ștampila CASSI, fără loc de proveniență se află în colecțiile MNIT ${ }^{122}$.

\section{b.2. „Măști de sclav”}

Printre opaițele descoperite în castrul roman de la Micia, aflate în colecțiile Muzeului Național de Istorie a României se găsesc și două exemplare cu discul ornamentat cu măști de sclav (nr. cat. 25, respectiv nr. cat. 56), de tipul Loeschcke X. Pe primul dintre acestea (nr. cat. 25) este reprezentată o mască de sclav, încadrată între două orificii de alimentare. Acest opaiț este marcat cu ștampila FORTIS. Pe cel de-al doilea exemplar (nr. cat. 56) sunt redate două măști de sclavi. Detaliile de realizare ale piesei, aspectul îngrijit al acesteia, caracteristicile pastei din care este confecționată, precum și cele mai apropiate analogii reprezintă elemente care ne conduc spre ipoteza conform căreia există probabilitatea ca și acest opaiţ să fi fost marcat cu ștampila unui producător. Acest fapt nu se poate însă afirma cu certitudine datorită faptului că din piesa nr. cat. 56 se păstrează doar un fragment din capac. Cele două decoruri descrise mai sus reprezintă măști de sclav din Comedia Nouă. Exemplarul decorat cu o mască (nr. cat. 25) își găsește similitudini în Dacia Superior. Piese cu decor identic pe disc, marcate tot cu ștampila FORTIS și foarte apropiate ca dimensiuni a fost descoperite la Tibiscum ${ }^{123}$ și Ulpia Traiana Sarmizegetusa ${ }^{124}$. Opaițe cu decor asemănător pe disc au fost descoperite la Alburnus Maior ${ }^{125}$, Apulum ${ }^{126}$, Corpadea ${ }^{127}$. În Dacia Porolissensis, lămpi decorate cu mască de sclav pe disc, au fost descoperite la Potaissa ${ }^{128}$ și Porolissum $^{129}$. Piese asemănătoare din punct de vedere al decorației de pe disc au fost descoperite pe cuprinsul întregului Imperiu. Însă, în acest studiu ne vom îndrepta atenția asupra analogiilor cu decor similar sau chiar identic. Amintim astfel, descoperirile de la Aquileia ${ }^{130}$, Carnuntum $^{131}$ și

\footnotetext{
${ }_{114}$ Băluță 1961, 194, nr. cat. VII/I, pl. I/8, XI/12.

${ }^{115}$ Mitrofan 1964, 200, 211, fig. 3/3.

${ }^{116}$ Băluță 1961, 206, nr. cat. XX/62, pl. VI/1-2; Băluță 2003, 89-90, nr. cat. XXXII/101, fig. XXXII/101.

117 Băluță 1961, 193, nr. cat. IV/1, pl. I/5, XI/4; Băluță 1989, 245, nr. cat. 26, pl. III/1; Băluță 2003, 11, nr. cat. VI/3, fig. VI/3.

${ }_{118}$ Băluță 2003, 15, nr. cat. VIII/1, fig. VIII/1.

${ }^{119}$ Băluță 2003, 30-31, nr. cat. XIII/21, fig. XIII/21.

${ }^{120}$ Băluță 2003, 102, nr. cat. XXXVI/1, fig. XXXVI/1.

${ }_{121}^{1}$ Băluță 1961, 214, nr. cat. XXXV/1, pl. IX/2, XII/4; Băluță 2003, 162-163, nr. cat. LXX/1, fig. LXX/1.

122 Băluță 1996, 94, nr. cat. 9, pl. VII/3.

${ }^{123}$ Benea 1990, 161-162, nr. cat. 54, fig. 7/54, opaiț marcat cu ștampila FORTIS.

124 Băluță 1977, 220, nr. cat. 26, pl. II/19 a-b, opaiț marcat cu ștampila FORTIS, 222, nr. cat. 59, opaiţ fără ștampilă; Lychnus et Lampas 2006, 64-65, nr. cat. 147 (voce Cristian Aurel Roman), 149, 150 (voce Adriana Isac), trei opaiţe marcate cu ștampila FORTIS.

${ }^{125}$ Alburnus Maior III, 208, nr. cat. 9, pl. 244/9, opaiț marcat cu ștampila CASSI.

${ }^{126}$ Băluță 1961, 197, nr. cat. XI/19, pl. III/4-5, opaiț marcat cu ștampila CASSI; Pop 1970, 158-160, nr. cat. 17, fig. 3/3, opaiț marcat cu ștampila FORTIS. Pentru aceeași piesă, vezi Băluță 1996, 100, nr. cat. 36, pl. III/5 și Băluță 2003, 84, nr. cat. XXXII/55, fig. XXXII/55.

${ }^{127}$ Pop 1970, 160, nr. cat. 18, fig. 3/4, opaiț marcat cu ștampila IANVARI/F. Pentru aceeași, vezi piesă Băluță 1996, 103, nr. cat. 68 , pl. V/6, XIII/9.

${ }^{128}$ Cătinaș 1996, 68, nr. cat. 15, pl. 73/15, pe un opaiț marcat cu ștampila LITOGENE.

${ }^{129}$ Matei et alii 2006, 60, nr. 60, fig. 60; Roman 2006, 116-117, nr. cat 104, pl. 12/104, 13/104, 20/104 pe un opait marcat cu ștampila FORTIS.

${ }^{130}$ Buchi 1975, 63, nr. cat. 395, pl. XXII/395 a-b, opaiț cu ștampila FESTI, 84, nr. cat. 582, pl. XXVIII/582 a-b, opaiț cu ștampila FORTIS, 132, nr. cat. 939, pl. XLVI/939 a-b, opaiţ cu ștampila OPTATI, 140, nr. cat. 963, pl. XLIX/963 ab, opaiț cu ştampila RVFIN. Trebuie amintit aici și un opaiț, cu un decor identic cu al piesei noastre pe disc, cu ştampila FORTIS imprimată pe bază, dar de tipul Loeschcke IX, 76, nr. cat. 440, pl. XXIV/440 a-b.
} 
Poetovio $^{132}$. O lampă decorată cu mască de sclav, descoperită probabil la Aquincum se află în colecțiile Muzeului Național Secuiesc din Sfântu Gheorghe ${ }^{133}$. La Vindonisa ${ }^{134}$, decoruri asemănătoare sunt întâlnite pe opaițe de tipul Loeschcke IX.

Cel de-al doilea exemplar (nr. cat. 56) are analogii la Apulum ${ }^{135}$, Ulpia Traiana Sarmizegetusa ${ }^{136}$, Porolissum ${ }^{137}$.

\section{REPERTORIUL ȘTAMPILELOR (PI. II)}

În urma analizei acestui lot de instrumente antice de iluminat provenite din castrul de la Micia s-a constatat faptul că un număr de 19 opaițe poartă pe bază ștampila unor producători: APRIO, ATIMETI, CAI, CAMPILI, FESTI, FORTIS, IANVARI, MIA, OPTATI, STROBILI. De asemenea, un exemplar (nr. cat. 35) nu a putut fi citit, având ștampilă ilizibilă.

\section{APRIO}

Producătorul care îşi marca astfel lămpile într-un atelier localizat în nordul Peninsulei Italice $^{138}$, începe să producă la începutul secolului al II-lea p. Chr. Trebuie menţionat faptul că valva inferioară a unui tipar având ștampila APRIO/F, descoperită la Bononia este păstrată la Muzeul din Aquincum ${ }^{139}$.

În provinciile dacice au fost repertoriate 14 exemplare ce purtau ştampila acestui producător. Acestea sunt reprezentante prin tipurile Loeschcke IX și X. Astfel de exemplare au fost descoperite în Dacia Superior, la Ampelum ${ }^{140}$, Alburnus Maior ${ }^{14 \hat{1}}$, Apulum $^{142}$, Tibiscum $^{143}$, Ulpia Traina Sarmizegetusa $^{144}$ și în Dacia Porolissensis, la Porolissum ${ }^{145}$. De asemenea, este menționat un exemplar, având loc de proveniență incert ${ }^{146}$.

În castrul de la Micia a fost descoperit un opaiț (nr. cat. 18) din a cărui ștampilă se păstrează litera O (PI. IX/2). Detaliile de realizare ale piesei, aspectul îngrijit al acesteia, precum și cele mai apropiate analogii reprezintă elemente care ne conduc spre ipoteza conform căreia opaițul în discuţie este un produs de import, nord-italic.

${ }^{131}$ Alram-Stern 1989, 225, nr. cat. 363, pl. 34/363.

${ }^{132}$ Curk 1976, 34, nr. cat. 2205, pl. XXI/2, opaiț marcat cu ștampila FORTIS

${ }^{133}$ Zăgreanu 2011, 169, nr. cat. 1, pl. 2/1, opaiț marcat cu ștampila FORTIS.

${ }^{134}$ Loeschcke 1919, 429, nr. cat. 789, pl. XIX/789, opaiț marcat cu ștampila COMVNIS, 431, nr. cat. 801, pl. XIX/801, opait marcat cu ștampila FORTIS.

${ }^{135}$ Băluță 2003, 30, nr. cat. XIII/20, fig. XIII/20.

${ }^{136}$ Lychnus et Lampas 2006, 63-64, nr. cat. 141-142, 144, fig. 141-142, 144, trei exemplare marcate cu ștampila FORTIS (voce Cristian Aurel Roman).

${ }^{137}$ Matei et alii 2006, 60, nr. cat. 61, fig. 61, opaiț marcat cu ștampila FORTIS.

${ }^{138}$ Loeschcke 1919, 296; Gostar 1961, 176 (autorul amintește un producător de terra sigillata datată în secolul al II-lea, la Rheinzabern, care își marchează produsele cu ștampila APRIO/F, pe care îl consideră diferit de Aprius, producătorul de lucerne); Buchi 1975, 7.

139 Iványi 1935, 315, nr. cat. 4540; Buchi 1975, 7, Băluță 2003, 8.

${ }^{140}$ Lipovan 1988, 182, nr. cat. I, pl. I/1; Băluță 1999, 226, nota 7.

${ }^{141}$ Bocan, Ursuțiu, Cociș 2007-2008, 204, 209, nr. cat. 4, pl. 1/4; Alburnus Maior III, 200, nr. cat. 1, pl 225/1; Bocan, Ursuțiu, Cociș 2008, 42, 47, nr. cat. 4, pl. 11/4

${ }^{142}$ CIL III, 1634, 2; Gostar 1961, 157, nr. cat. 14; Băluță 1961, 193, nr. cat. III; Băluță 1983, 48; Băluță 1999, 226, nr. cat. 1; IDR III/6, 363-363a; Băluță 2003, 8-10, nr. cat. 1-3.

${ }^{143}$ Benea 1990, 146, 157-158, nr. cat. 37-39, fig. 3,/38, 5/37, 39, fig. 14/37 a-b.

${ }^{144}$ Alicu 1976, 207, nr. cat. 3-5, pl. 1/2-4, pl. 3/1; Alicu 1994, 13-14, 171-172, 190, nr. cat. 469,486-487, 1100, pl. IX/469, X/487, XXX/1100, fig. 6/469, 13/469, 486-487, 1100; Alicu 2006, 11-12, 114, 117, 169, Kat. 469, 486-487, 1100, Taf. IX/469, 487, XXIII/1100; Lychnus et Lampas 2006, 54, nr. cat. 83-84,pl. 106/83-84 (voce Adriana Isac).

${ }^{145}$ Matei et alii 2006, 78, nr. cat. 103, fig 103; Roman 2006, 55-56, 110-111, nr. cat. 87, pl. 13/87, pl. $19 / 87$.

${ }^{146}$ Gostar 1961, 157, nr. cat 15. 


\section{ATIMETI}

Officina producătorului Atimetus a funcționat în Peninsula Italică. În ceea ce privește localizarea atelierului opiniile sunt împărțite. Loeschcke localizează sediul acestui atelier în nordul Peninsulei Italice ${ }^{147}$. Tot acestui meșter i se atribuie un sediu la Roma ${ }^{148}$, de către Emile Thévenot, care ajunge la această concluzie pe baza analizei opaițelor publicate în Corpus Inscriptionum Latinarum $^{149}$.

Atimetus începe să producă lămpi încă din secolul I p. Chr, continuând până la jumătatea secolului al II-lea. Acestea sunt reprezentante prin tipurile Loeschcke IX și X.

În provinciile dacice au fost repertoriate 40 de exemplare având înscrise pe bază marca acestui producător, în Dacia Superior la Ampelum ${ }^{150}$, Apulum $^{151}$, Arcidava (Vărădia) ${ }^{152}$, Cristești ${ }^{153}$, Micia $^{154}$, Sebeș (?) ${ }^{155}$, Ulpia Traiana Sarmizegetusa ${ }^{156}$, în Dacia Inferior la Romula ${ }^{157}$ și în Dacia Porolissensis, la Aiton ${ }^{158}$, Napoca $^{159}$, Porolissum ${ }^{160}$, Potaissa ${ }^{161}$, Românași ${ }^{162}$, Sânpaul ${ }^{163}$.

În castrul de la Micia au fost descoperite trei opaițe având ștampila ATIMETI: un exemplar este încadrabil în tipul Loeschcke IX (nr. cat. 14), iar alte două exemplare aparțin tipului Loeschcke X (nr. cat. 19 - greu lizibilă și nr. cat. 20).

Piesa de la Micia, încadrată în tipul Loeschcke IX (nr. cat. 14) suscită un interes deosebit datorită decorului de pe disc, rozetă cu opt lobi, realizată în relief, într-o manieră particulară (PI. IX/1). Două exemplare asemănătoare au fost descoperite la Apulum ${ }^{164}$ și la Porolissum ${ }^{165}$. Cele mai apropiate analogii, coroborate cu detaliile stilistice (motivul floral de pe disc, realizat în relief, întro manieră particulară) remarcate exclusiv pe piesele din provinciile dacice, încadrate în tipul Loeschcke IX, conduc către evidențierea unei serii tipologice, acesta fiind unul dintre argumentele identificării unor ateliere locale, care produc lămpi marcate cu ștampila ATIMETI, fie la Micia, fie în alte centre din Dacia (Apulum sau Porolissum).

Cel de-al doilea exemplar (nr. cat. 19), încadrat în tipul Loeschcke X, se remarcă tot prin detaliile stilistice (PI. IX/3). Motivul floral care ornamentează discul, realizat tot în relief într-o manieră particulară ne oferă importante indicii care ne determină să atribuim piesa unui atelier provincial, sau chiar local.

${ }^{147}$ Loeschcke 1919, 274.

${ }^{148}$ Thévenot, Fromageot-Girardet 1948, 329, nr. cat. 18.

${ }^{149}$ CIL XV, 6320.

${ }^{150}$ Lipovan 1983-1984, 304, pl. V/2; Lipovan 1988, 182, nr II, 1, pl. I/2; Beldiman 1989, 268, nr. cat. 11.

${ }^{151}$ CIL III, 8076,6b = 6286, 1; Gostar 1961, 158, nr. cat. 27-31; Băluță 1961, 194-195, nr. cat. VII /1-4, pl. I/4, 7-8, pl. XI/12; IDR III/6, 366; Băluță 1983, 50-52, LVI/ 2, 5 a-b, pl. LVII/3a-b, 4a-b, 8a-b, 7a-b, 9a-b, 10a-b, XCVI/3-6, 8, 10, 14, 22; Băluță 1989, 246, nr. cat. 27, pl. V/3; Băluță 2003, 15-18, nr. cat. VIII/1-12.

152 Beldiman 1989, 267, nr. cat. 9; Alicu 1994, 16, nota 91; Băluță 2003, 15, nota 14; Alicu 2006, 13, nota 91.

${ }^{153}$ Băluță 1983, 50, pl. LVI/6, LVII/1a-b, 2a-b, XCVI/7, 11-12; Man 2011, 171, 183, nr. cat. 22, 26, pl. CXXV/22, pl. $\mathrm{CXXVI} / 26$

154 Torma 1870, 305; Russu 1962, 469; Beldiman 1989, 267, nr. cat. 10.

155 Beldiman 1989, 267, nr. cat. 6; Băluță 1996, 92, nr. cat. 3, pl. IX/3; Lychnus et Lampas 2006, 81, nr. cat. 260, pl. 134/260 (voce Adriana Isac).

${ }^{156}$ Alicu 1976, 207, nr. cat. 6-7, pl. 1/5-6, 3/2; Alicu 1985, 85, pl. II, V; Alicu 1994, 16, 169-170, 172, 181, 183, 190, nr. cat. $422,439,489,774,820,1102-1105$, fig. 13/422, 439, 489, 774, 820, 1102-1105, fig. 22-24, pl. 8/439, 11/489, 17/774, 20/820, 30/1103-1105; Alicu 2006, 13-14, 107, 109 ,118, 144, 149, 170, Kat. 422, 439, 489, 774, 820, 11021105, Taf. VIII/439, X/489, XIV/774, XXIII/1103-1105.

${ }^{157}$ Gostar 1961, 158, nr. cat. 32; Tudor 1937, 121, nr. cat. 318; Tudor 1978, 90; Beldiman 1989, 267, nr. cat. 3.

${ }^{158}$ Moțu 1991, 190, nr. cat. 5, pl. XXI/5 (citit eronat AVITI)

${ }^{159}$ Russu 1962, 469; Mitrofan 1964, 200-201, 211, fig. 3/3; Beldiman 1989, 267, nr. cat. 2.

${ }^{160}$ Gudea 1989, 448, nr. cat. 21, pl. XI/21; Matei et alii 2006, 76, 77, 84, nr. cat. 100, 101, 119, fig. 100, 100b, 101, 101b, 119; Roman 2006, 111, nr. cat. 88, pl. 13/88, 19/88.

${ }^{161}$ CIL III, 8076, 6a = 6286,1; Gostar 1961, 158, nr. cat. 33 .

${ }^{162}$ Russu 1962, 469; Beldiman 1989, 267, nr. cat. 4.

${ }^{163}$ Beldiman 1989, 266-267, nr. cat. 2, fig. 3/1-2; Russu 1962, 469.

${ }^{164}$ Băluță 2003, 15-16, nr. cat. VIII/2, fig. VIII/2.

${ }^{165}$ Matei et alii 2006, 84, nr. cat. 119, fig. 119. 
Al treilea exemplar purtând această marcă (nr. cat. 20) este un produs provincial, concluzie argumentată de analiza grafică a ștampilei, calitatea pastei, precum și, modalitatea de finisare a piesei (PI. IX/4). Cea mai apropiată analogie a acestei piese o aflăm la Porolissum ${ }^{166}$.

CAI

Această marcă poate desemna fie iniţialele producătorului, care purta tria nomina, fiind cetăţean roman C(AIVS) A[....] I[.... ${ }^{167}$, fie forma de genitiv a numelui producătorului, Caius ${ }^{168}$. Un opaiţ cu marca GAIVS este cunoscut la Aquileea ${ }^{169}$, în timp ce la Cristeşti a fost descoperită o piesă cu inscripţia GAI ${ }^{170}$.

Marca acestui producător, în formă CAI, este cunoscută numai în Dacia Superior, fiind repertoriate 14 exemplare la Apulum ${ }^{171}$, Alburnus Maior ${ }^{172}$, Cristeşti ${ }^{173}$, Micăsasa ${ }^{174}$, Micia $^{175}$, Sighişoara $^{176}$, Ulpia Traiana Sarmizegetusa ${ }^{177}$ şi Tibiscum ${ }^{178}$.

În castrul de la Micia a fost descoperit un singur exemplar, încadrat în tipul Loeschcke X (nr. cat 21), ce are înscrisă pe bază ștampila CAI (PI. IX/5). Cele mai apropiate analogii ale acestei lămpi se găsesc la Alburnus Maior și la Tibiscum, piesa în discuție fiind produsul unui atelier provincial. Ipoteza se bazează pe faptul că numele acestui producător de opaițe nu apare în nicio altă provincie a Imperiului Roman.

\section{CAMPILI}

Atelierul lui Campilius a funcționat în nordul Peninsulei Italice ${ }^{179}$. În ceea ce privește perioada în care și-a desfășurat activitatea, părerile specialiștilor sunt împărțite. După Loeschcke șiar fi desfășurat activitatea la începutul secolului al II-lea ${ }^{180}$ p. Chr., iar Gostar și Buchi propun o datare cuprinsă între sfârșitul secolului al II-lea - până la începutul secolului al III-lea p. Chr. ${ }^{181}$ Marca sa este imprimată exclusiv la genitiv. În provinciile dacice au fost repertoriate 24 de exemplare. În Dacia Superior opaițe semnate de producătorul Campilius au fost descoperite la Apulum $^{182}$, Tibiscum ${ }^{183}$ și Ulpia Traiana Sarmizegetusa ${ }^{184}$. În Dacia Porolissensis sunt întâlnite în

\footnotetext{
${ }^{166}$ Matei et alii 2006, 76, nr. cat. 100, fig. 100, 100b.

167 Gostar 1961, 193.

168 Băluță 2003, 1 .

${ }^{169}$ Buchi 1975, 101-102, nr. 794, pl. XXXV.

${ }^{170}$ CIL III, 12012, 44.

${ }^{171}$ Băluță 1983, 53, pl. LVIII/2 a-b, XCVI/25; IDR III/6, 369 b; Băluță 2003, 1-3, nr. cat. I/1-3.

172 Bocan, Ursuțiu, Cociș 2007-2008, 204-205, 209-210, nr. cat. 5-7, 1/5, pl. 2/6-7; Alburnus Maior III, 76, 172, 183, nr. cat. 13 , pl. $7 / 13$, nr. cat. 1, pl. 167/1, nr. cat. 5, pl. 185/5; Bocan, Ursuțiu, Cociş 2008, 42, 47, nr. cat. 5-7, pl. 11/5, $12 / 6-7$.

${ }^{173}$ Gostar 1961, 158, nr. 34, fig. 10; Băluță 1983, 53, pl. XCVI/23-24, 26; Lychnus et Lampas 2006, 82, nr. cat. 263 , pl. 134/263 (voce Nicoleta Man).

174 Alicu 1994, 17, 202, nota 97.

${ }^{175}$ Băluță 1977, 225, nr. cat. 93, pl. V/49a-b; Băluță 1983, 53, pl. LVIII/3 a-b, XCVII/2.

176 Băluță 1983, 53, pl. XCVII/3.

177 Băluţă 1983, 53, pl. XCVII/1; Alicu 1985, 85, pl. II, V; Alicu 1994, 17, 172, 190, nr. cat. 490, 1109; Alicu 2006, 14, 118, 171, Kat 490, Taf. X/490, Kat. 1109; Lychnus et Lampas 2006, 71-72, nr. cat. 195, pl. 125/195 (voce Adriana Isac).

${ }^{178}$ Benea 1990, 147, 159, nr. 42, fig. 6/42; Benea 1996, 59, pl. 2/2; Hamat, Georgescu 2013, 227, pl. II/8.

${ }^{179}$ Buchi 1975, 16.

${ }^{180}$ Loeschcke 1919, 296.

${ }^{181}$ Gostar 1961, 177-178; Buchi 1975, 17.

${ }^{182}$ CIL III 1634,4; 8076, 7; Gostar 1961, 158, nr. cat. 35-36, 38; Băluță 1961, 195, nr. cat. IX /2-4, pl. I/9, pl. II/1-3; Tudor 1978, 90; Băluță 1983, 53-54, pl. LIX/ 3 a-b, 4 a-b, 5 a-b, 7 a-b, XCVII/5, 6, 8; Băluță 1989, 246, nr. cat. 28, pl. IV/5; Băluță 1996, 93, nr. cat. 5, pl. I/1; Băluță 2003, 21-23, nr. cat. X/1-9.

183 Benea 1990, 147, 159, nr. cat. 43, fig. 14/43.

${ }^{184}$ Alicu 1976, 207, nr. cat. 8, pl. 1/7; Alicu 1994, 172, 190, nr. cat. 491,1110, fig. 13/491, 1110, pl. 30/1110; Alicu 2006, 118,171 , Kat 491, 1110, Taf. XXIII/1110.
} 
castrele de la Buciumi ${ }^{185}$, Gherla ${ }^{186}$ şi Porolissum ${ }^{187}$. În Dacia Inferior a fost descoperit un singur exemplar, la Romula ${ }^{188}$. Se impune menționată o lampă cu această marcă descoperită în Transilvania ${ }^{189}$, precum și alte două opaițe cu loc de proveniență necunoscut ${ }^{190}$. De asemenea, o lampă de proveniență necunoscută se află la Muzeul de Istorie Aiud, iar alta, fragmentară, în Complexul Muzeal Arad. Aceasta din urmă a fost primită la schimb de la Muzeul Național din Budapesta ${ }^{191}$. Un alt opaiț, de asemenea, fără contextul descoperirii, se află la Muzeul Județean de Istorie și Arheologie Prahova (Ploiești ${ }^{192}$ ).

În castrul de la Micia au fost descoperite două opaițe încadrate în tipul Loeschcke X (nr. cat. 22-23), ce poartă pe bază ștampila CAMPILI (PI. IX/6-7). Calitatea superioară a pastei, aspectul general îngrijit al celor două piese, deosebita atenție asupra detaliilor și grafia ștampilelor sunt argumente care ne determină să atribuim aceste opaițe unui atelier nord-italic.

\section{FESTI}

Officina producătorului Festus este localizată în nordul Italiei ${ }^{193}$. Marca sa este imprimată la genitiv, la nominativ ${ }^{194}$ şi în varianta COR FEST ${ }^{195}$. Piesele acestui meşter sunt răspândite în multe din provinciile Imperiului roman. În provinciile dacice au fost repertoriate 38 de lămpi cu ştampila acestui producător: în Dacia Superior, la Alburnus Maior ${ }^{196}$, Apulum ${ }^{197}$, Boteş-Corabia ${ }^{198}$, Cristești $^{199}$, Ghelari ${ }^{200}$, Tibiscum ${ }^{201}$ şi Ulpia Traiana Sarmizegetusa ${ }^{202}$, în Dacia Porolissensis, la Gherla $^{203}$, Gilău ${ }^{204}$, Ilişua ${ }^{205}$, Porolissum ${ }^{206}$ şi Romita ${ }^{207}$. De asemenea, în literatura de specialitate este menționat și un exemplar din Transilvania fără loc de proveniență cert ${ }^{208}$.

În castrul de la Micia a fost descoperit un exemplar (nr. cat. 24), încadrat în tipul Loeschcke X, purtând această ștampilă (PI. IX/8). Calitatea superioară a pastei, aspectul general

${ }^{185}$ Chirilă et alii 1972, 55-56, nr. cat 17, 46, pl. XLIII/6, pl. XLVI/6; Matei et alii 2006, 68, nr. cat. 79-81, fig. 79-81; Roman 2006, 111,126, nr. cat. 90, 133, pl. 9/90, pl. 13/90 şi pl. 10/133, pl. 13/133; Gudea, Cosma 2008, 121, nr. cat. 7-8, pl. 91/7-8.

${ }_{186}$ Russu 1962, 469; Băluță 1983, 54, pl. XCVII/10; Băluță 2003, 24, nota 9.

${ }^{187}$ Roman 2006, 111, nr. cat. 89, pl. 9/89, pl. 13/89.

${ }^{188}$ IDR II, 440; Tudor 1937, 120,121, nr. cat. 312, fig. 58 d; Gostar 1961, 158, nr. cat. 37; Tudor 1978, 90.

189 Băluță 2003, 21.

${ }^{190}$ Băluță 2003, 21; Topoleanu 2010, 175, pl. I/2.

${ }^{191}$ Băluță 2003, 21.

192 Topoleanu 2010, 156-157, 175, nr. cat. 2, pl. I/2.

${ }^{193}$ Loeschcke 1919, 296.

${ }^{194}$ Buchi 1975, 61-62, nr. cat. 387, pl. XXI/387a-b.

${ }^{195}$ CIL V, 8114, 29

${ }^{196}$ Moga et alii 2003, 207; Bocan, Ursuțiu, Cociș 2007-2008, 205-206, 210, nr. cat 16-17, pl. 3/16-17; Alburnus Maior III, 134, 214, nr. cat 3, pl. 102/3,nr. cat. 7, pl. 262/7; Bocan, Ursuțiu, Cocis 2008, 43, 47, nr. cat. 16-17, pl. 13/16-17.

${ }^{197}$ CIL III, 8076, 15 a; CIL III, 8076, 15 b; Cserni 1912, 276, 279, fig. 19; Gostar 1961, 161, nr. 123-128; Băluță 1961, 201-202, nr. cat. XIX, 1-8, pl. V/1-3, XI/5, 9; Băluță 1983, 67-69, pl. LXVII/8-9, 13 a-b, 14, CI/1-5, 7-8, 10 LXVIII/1 a-b, 3 a-b, 4 a-b; Băluță 1996, 98, nr. cat 30, pl. I/8; IDR III/6, 383, fig. 380; Băluță 2003, 67-70, nr. cat XXVIII/1-9; Lychnus et Lampas 2006, 81, nr. cat 254, pl. 133/254 (voce Adriana Isac).

${ }^{198}$ CIL III, 8076, 15c; Gostar 1961, 161, nr. 130; Băluță 1961, 201, nota 5; Lipovan 1982-1983, 230; Băluță 2003, 69, nota 8 .

${ }^{199}$ Gostar 1961, 161, nr. 131; Băluţă 1983, 67, pl. LXVII/11, CI/14; Băluță 2003, 70, nota 10; Man 2011, 187, nr. cat. 48, pl. CXXXII/48.

200 Băluță 1961, 201, nota 5; Russu 1962, 469.

${ }^{201}$ Benea 1990, 160, 164, nr. cat. 51-52, 52a; fig. 7/52, fig. 11/51, fig. 14/51; Regep 2001, 83-84, nr. cat. 2-4, pl. I/2, pl. II, pl. III.

${ }^{202}$ Alicu 1976, 209, nr. cat. 19, pl. 1/19, 3/8; Alicu 1994, 21, 169, 172, 190, nr. 423, 496-498, 1116-1117 fig. 14/423, 496-498, 1117, pl. 11/496-497; Alicu 2006 18, 107, 119-120,172, Kat. 423, 496-498, 1116, 1117, Taf. VII/423, X/496, XXIII/1117; Lychnus et Lampas 2006, 81, nr. cat. 255, pl. 133/255 (voce Adriana Isac).

${ }^{203}$ Băluță 1961, 201, nota 5; Russu 1962, 469.

${ }^{204}$ Băluţă 1996, 98, nr. cat. 33, pl. XII/8; Isac 1997, 109, Taf. XXVIII/5; Isac, Roman 2001, 373, nr. cat. 21, 24, pl. IV/ 21a-b, 24a-b, pl. VII/21b, 24b; Roman 2006, 63, 114-115, nr. cat. 96, 98-99, pl. 13/96, 98-99, pl. 19/96.

${ }^{205}$ Băluță 1996, 98, nr. cat. 34; Gostar 1961, 161, nr. 132.

${ }^{206}$ Russu 1962, 469; Gudea 1989, 453, fără număr catalog; Băluţă 1996, 98, nr. 31-32, pl. XII/12-13; Roman 2006, 63, 114, 128-129, 137, pl. 13/97, 139, pl. 14/168.

${ }^{207}$ Matei et alii 2006, 75, nr. cat. 98, fig. 98-98b

${ }^{208}$ Băluță 2003, 70, nota 17. 
îngrijit al piesei, deosebita atenție asupra detaliilor, grafia ștampilei, precum și cele mai apropiate analogii sunt argumente care ne determină să atribuim acest opaiț unui atelier nord-italic.

\section{FORTIS}

Este cel mai prolific şi cel mai cunoscut producător din Imperiul Roman, officina inițială a acestui meşter fiind localizată, cel mai probabil, la Savignano sul Panaro, în apropiere de Mutina (Modena). Această ipoteză este bazată pe descoperirea a numeroase tipare și opaițe asociate cu o tegula, marcată cu ștampila AD FORN(aces,-acem) CAT(...) L. AEMILI/FORTIS ${ }^{209}$. Un alt argument pentru confirmarea acestei ipoteze este reprezentat de descoperirea la Cesalerone, în apropierea Veronei, a unui opaiț cu ștampila M(utinae) FORTIS F(ecit) ${ }^{210}$. O altă descoperire, la Modena, în necropola din Parco Novi Sad (mormântul 365) a unui opaiț cu ștampilă retrogradă în tabula ansata, M(utinae) FORTIS F(ecit), datat la începutul secolului I, conduce la concluzia conform cărei acest producător este creatorul opaițelor de tip Firmalampen ${ }^{211}$. Această descoperire infirmă ipoteza emisă de Loeschcke conform căreia Strobilus ar fi primul producător al acestor tipuri de opaițe ${ }^{212}$.

În provinciile Imperiului Roman, sunt cunoscute 13 forme $^{213}$ de redare ale ștampilei: FORTIS, FORTI, FORTIS/N, FORTIS/A, FORTIS/E，FORTIS/I，FORTIS/L， FORTIS/P, FORTI/S, O/FORTIS, M/FORTIS/F, S/FORTI, FORTIS/S. În provinciile dacice sunt repertoriate 452 de exemplare ${ }^{214}$, lămpile cu ştampila acestui producător fiind imprimate cu primele trei forme menționate mai sus. Opaițe cu ștampila FORTIS au fost descoperite în Dacia Superior, la Abrud ${ }^{215}$, Alburnus Maior ${ }^{216}$, Ampelum $^{217}$, Apulum $^{218}$, Berghin $^{219}$, Berzovia ${ }^{220}$, Bistriţa ${ }^{221}$, Boroșneul Mare ${ }^{222}$, Cincu Mare ${ }^{223}$, Costeşti ${ }^{224}$, Creaca ${ }^{225}$, Cristeşti ${ }^{226}$, Deva ${ }^{227}$, Dumbrăveni ${ }^{228}$ Ghirbom $^{229}$, Gornea ${ }^{230}$,

${ }^{209}$ CIL XI, 6689,12, Loeschcke 1919, 496

${ }^{210}$ Loeschcke 1919, 282, 496; Buchi 1975, 65.

${ }^{211}$ Labate 2013, 38-39, fig. 25-27.

212 Loeschcke 1919, 288-290.

213 Buchi 1975, 65

214 Repertorierea este dificil de urmărit, datorită informațiilor lacunare și contradictorii pentru unele dintre locurile de proveniență a acestor opaițe, astfel încât cifra exactă este greu de stabilit.

215 Bălută 1989, 251, nr. cat. 42, pl. III/7

${ }^{216}$ Gostar 1961, 164, nr. cat. 223; Băluță 1983, 72, LXIX/4, CII/4; Băluță 1996, 100, nr. cat. 39, pl. III/2; Moga et alii 2003, 195 fig. 29/9, 202, 205, fig. 28/1; Simion, Apostol, Vleja 2004, 31, 57, nr. 47, pl. 42/47; Bocan, Ursuțiu, Cociș 20072008, 210, nr. cat. 18-31, pl. 3-4/18-31; Alburnus Maior III, 106, nr. cat. 4, pl. 60/4; 114, nr. cat. 8, pl. 72/8; 161, nr. cat. 5 , pl. $145 / 5$; 168, nr. cat. 6 , pl. 159/6; 184, nr. cat. 9 , pl. 187/9; 185, nr. cat. 4, pl. 191/4; 199, nr. cat. 13-14, pl. 222/1314; 205, nr. cat. 4-5, pl. 236/4-5; 206, nr. cat. 2, pl. 238/2; 207-208, nr. cat. 5, pl. 242/5; 211, nr. cat. 1, pl. 252/1; 225, nr. cat. 1, pl. 294/1; Bocan, Ursuțiu, Cociș 2008, 47, nr. cat 18-31, pl. 13-15/18-31; Bocan et alii 2010, 76-77, pl. 11/8.

217 CIL III, 1634, 7a; Gostar 1961, 164, nr. cat. 217-222; Băluţă 1961, 202-203, nota 5; Lipovan 1982-1983, 227-228, nr. cat. 1, 3, pl. I/1,1 a, 3,3 a; Lipovan 1983-1984, 304, pl. V/3; Lipovan 1988, 182-185, III, 1-6, pl. I/3-4, II/2; Băluță 1996, 100, nr. cat. 40-42, pl. III/4; VI/2, XIII/2; Lychnus et Lampas 2006, 80, 133, nr. cat. 252, fig. 252 (voce Adriana Isac).

${ }^{218}$ CIL III, 8076, 16, k și m; Cserni 1912, 276, 279-280, fig. 19; Băluță 1961, 202-207, nr. cat. XX 1-68, pl. V/ 4-9, VI/1-2, pl XII/1-3, 6; Pop 1970, 158-160, nr. cat 17, fig. 3/3; Protase 1974, 151, fig. 15/1-2; Băluță 1989, 249-251, nr. cat. 40-41, 43, 47, 50, pl. II/9, III/6, 9, IV/8, V/5, 7, VI/5, Băluță 2003, 74-91, nr. cat. 1-110, Egri 2005, 85, pl. 35/7-8, fig.2, fig. 2/7-8.

${ }^{219}$ CIL III, 8076, 16, 1; Gostar 1961, 164, nr. cat. 244.

${ }^{220}$ Gostar 1961, 164, nr. cat 240; Băluță 1961, 202-203, nota 5.

${ }^{221}$ Băluță 1983, 72, nr. cat. 25, pl. CVII/25; Băluță 1996, 101, nr. cat. 53, pl. 13/4.

222 Zăgreanu 2011, 169, nr. cat. 2, pl. 2/2.

${ }^{223}$ Gostar 1961, 164, nr. cat. 245; Băluță 1983, 72, pl. CV/24; Băluță 1996, 101, nr. cat. 51, pl. IV/7.

224 Gostar 1961, 164, nr. cat. 248; Băluță 1961, 202-203, nota 5; Băluță 1996, 101, nr. cat. 58.

225 Băluță 1961, 202-203, nota 5; Băluță 1983, 72, pl CV/28; Băluță 1996, 101, nr. cat. 59.

226 Gostar 1961, 164, nr. cat. 237-239; Băluță 1961, 202-203, nota 5, Băluță 1983, 72, pl. LXXII/2; pl. LXXIII/4, pl. LXXIX/12, pl. LXXX/6, pl. LXXXII/4-5, pl. CII/19-20, CIII/9, pl. CV/21, pl. CVII/37, CVIII/4; Man 2011, 180, nr. cat. 1, pl. CXVIII/1, 181, nr. cat. 4, pl. CXIX/4, 182, nr. cat. 16, pl. CXXII/16, 187, nr. cat. 54, pl. CXXXIV/54.

227 Băluță 1977, 220, nr. cat. 27; Băluță 1983, 72, pl. LXXIX/8 şi CIII/13.

228 Băluță 1961, 202-203, nota 5.

229 Blăjan 1989, 296, nr. cat. 10.

${ }^{230}$ Gudea 1973, 586, nr. cat. 1, 4, fig. 14/1, 4, 17/7-9; Gudea 1977, 185, nr. cat. V, fig. XVII/5. 
Grădiştea Muncelului ${ }^{231}$, Lugoj ${ }^{232}$, Micia $^{233}$, Odorhei ${ }^{234}$, Orăştioara de Sus $^{235}$, Petroşani ${ }^{236}$, Radna Nouă $^{237}$, Rucăr ${ }^{238}$, Ruda Brad $^{239}$, Salinae (Uioara) ${ }^{240}$, Sâmboteni ${ }^{241}$, Sebeş ${ }^{242}$, Sighişoara ${ }^{243}$, Târnăveni ${ }^{244}$, Tibiscum $^{245}$ şi Ulpia Traiana Sarmizegetusa ${ }^{246}$, în Dacia Inferior, la Drajna de Sus ${ }^{247}$, Drobeta $^{248}$, Romula ${ }^{249}$, Rusidava ${ }^{250}$, Slăveni ${ }^{251}$ şi Sucidava ${ }^{252}$ şi în Dacia Porolissensis, la Bologa $^{253}$, Bucium ${ }^{254}$, Gherla ${ }^{255}$, Gilău ${ }^{256}$, Ilişua ${ }^{257}$, Napoca ${ }^{258}$, Porolissum ${ }^{259}$, Potaissa ${ }^{260}$,

${ }^{231}$ CIL III, 8076, 16, g; Gostar 1961, 164, 202-203, nr. cat. 247, nota 5; Băluță 1996, 101, nr. cat. 57; Lychnus et Lampas 2006, 47, 101, nr. cat. 36-37, fig. 36-37 (voce Eugen Iaroslavschi).

${ }^{232}$ CIL III, 8076, 12; Gostar 1961, 165, nr. cat. 253; Băluță 1961, 202-203, nota 5; Băluță 2003, 96, nota 55.

${ }^{233}$ CIL III 8076, 16, h; Gostar 1961, 164, nr. cat. 224-229; Băluță 1977, 219, nr. cat. 22; Băluță 1996, 101, nr. cat. 4350, pl. I/7, II/7-9, VI/1, 4, 6, 7, XIII/3,6.

${ }^{234}$ CIL III 8076, 16, f; Gostar 1961, 164, nr. cat. 243; Băluță 1961, 202-203, nota 5.

${ }^{235}$ Gostar 1961, 164, nr. cat. 242; Băluță 1996, 101, nr. cat. 60.

${ }^{236}$ Băluță 1961, 202-203, nota 5; Băluță 1996, 101, nr. cat. 61 .

${ }^{237}$ Băluță 1996, 101, nr. cat. 52, pl. I/4.

${ }^{238}$ Bogdan-Cătăniciu 1974, 282, fig. 283/4; Negru 1996, 75, fig. 1/1.

239 Băluță 2003, 75 nota 47.

${ }^{240}$ Gostar 1961, 164, nr. cat. 233-234; Băluță 1961, 202-203, nota 5; Băluță 1983, 72, pl. LXIX/1, CII/1; Băluță 1989, 251, nr. cat. 49, pl. III/5.

${ }^{241}$ Gostar 1961, 165, 259; Băluță 1996, 101, nr. cat. 54, pl. XIII/10.

${ }^{242}$ Gostar 1961, 164, nr. 249; Băluță 1983, 72, pl. LXXXI/5, CIII/32, CVII/18.

${ }^{243}$ Gostar 1961, 164, nr. cat. 249, Băluță 1983, 72, pl. CVII/18.

${ }^{244}$ Gostar 1961, 164, nr. cat. 246; Băluţă 1983, 72, pl. LXXXI/1, CV/22; Băluță 1989, 251, nr. cat. 51, pl. III/4.

${ }^{245}$ Benea 1990, 148-149, 162, nr. cat. 54-73, fig. 7/15, 60, 62-67, 11/67, 73, 15/ 54-59, 61, /70 A-B, 71, 72 A-B.

${ }^{246}$ Alicu 1985, 85, pl. II, V; Alicu 1994, 169-174,181,183,190-192, nr. cat. 418-420, 424-427, 440-447, 462, 473-478, 480, 484, 500-536,777-781, 821-825, 1118-1157, 1244-1245, pl. 6/418, pl. 7/424,426,427, pl. 8/441-442, pl. 9/473, pl. 10/475476, pl. 11/502, 504, 509, pl. 12/521-527, pl. 13/514, 520, 528-535, pl. 15/500, pl. 18/778-780, pl. 19/777, 781, pl. 20/822, pl. 29/1117-1118, 1121-1123, 1125-1127, 1131, 1133, 1135-1137, fig. 6/418-419, fig. 14/418-420, 424-425, 427, 441$442,507,510-513,515,526-527,821,825,1125,1137$, fig. 15/443-445, 447, 462, 473,475-476, 478, 484,500-506, 508509, 513-514, 516-525, 528, 530, fig./531-532, 534-536, 777-780, 824, 1118, 1121-1122, 1126-1127, 1133-1136, 11381143, 1145-1151, 1155, fig. 17/1154, fig. 19/1130; Alicu 2006, 106, 108, 110-113, 115-116, 120-129, 144-145, 149-151, 173-180, 188, Kat. 418-420,424-427, 440-447, 462,473-478, 480, 484, 500-536, 777-781, 821-825, 118-1157, 1244 1245, Taf. VII/418-420,424, VIII/426-427, 441-442, IX/473, 475-476, 478, 484, XI/500, 502, 504-505, 509, 514-516, 520-523, XII/524-535, 777-781, XVII/821-823, 825, XXIII/1118, 1121, XXIV/1122-1123, 1125-1127, 1133, 1135-1136, 1150, 1154-1157; Lychnus et Lampas 2006, 117-118, 125, nr. cat. 140-142, 149, 198, fig. 140-142, (voce Cristian Aurel Roman) 149, 198 (voce Adriana Isac); Höpken, Fiedler 2008, 148, pl. 111/11, 13 a-b.

${ }^{247}$ Gostar 1961, 165, nr. cat. 260; Băluță 1961, 202-203, nota 5; Topoleanu 2010, 165, 176, nr. cat. 6, 8, pl. II/6, 8.

${ }^{248}$ CIL III 8076, 16.i; Bărcăcilă 1934, 466, fig. 41-42; Gostar 1961, 163, nr. cat. 208; Băluță 1961, 202-203, nota 5; IDR II, 122; Cristescu 2004, 68.

${ }^{249}$ IDR II, 444, Tudor 1937, 121, nr. cat. 315, fig. 58 a; Tudor 1978, 89, 91, fig. 23/8; Gostar 1961, 163, nr. cat. 209; Băluță 1961, 202-203, nota 5; Negru, Bădescu 2005, 254, no. 9, pl. 119/fig. 2/9; Negru, Bădescu, Avram 2008, 193, no. 12.

${ }^{250}$ Tudor 1968, 405; IDR II, 569.

251 Bondoc 2012, 37, fig. 15.

${ }^{252}$ Tocilescu 1902, 373-374; IDR II, 294; Gostar 1961, 164, nr. cat. 230-232; Gherghe, Cojoc 2011, 76-77, nr. cat. 6870, pl. 46/66-67.

${ }^{253}$ Gudea 1977, 185, nr. cat. 5, 9, fig. 17/5, fig. 17/9.

${ }^{254}$ Chirilă et alii 1972, 54-56, nr. cat. 3, 5, 10-11, 42, pl. XLII/1, 4, 8-9, XLVI/2; Băluță 1983, 72, pl. CIII/6, 28, CIV/6, CVIII/ 3; Matei et alii 2006, 61-63,65, nr. cat. 63, 66-67, 69, pl. 63-63b, 66-67, 73; Roman 2006, 107-108, nr. cat. 78-79, pl. 13/79; Gudea, Cosma 2008, 120-122, 124, nr. cat 4, 12-13, 18, 25, 33.

255 Băluță 1961, 202-203, nota 5; Russu 1962, 469; Szentléleky 1969, 91, nr. cat 134; Băluță 1983, 72, 108, 110, nr. cat. $1-3$, trei opaițe fără număr de catalog, pl. LXXXIV/1-3.

${ }^{256}$ Isac, Roman 2001, 374, nr. cat. 22, 29, 32-33, 36-38, pl. V/ 22, 29, 32-33, 36-38, pl. 22b, 29b, 32-33, 36-38, Roman 2006, 117, 130-133, nr. cat. 106, 144, 150, 153, 154, pl. 10/155, pl. 13/20, pl. 14/ 144, 150, 153, pl. 14/155, pl. 20$22 / 106,144,150,153$

${ }^{257}$ CIL III 8076, 16, c; Gostar 1961, 164, nr. cat. 235-236; Băluță 1961, 202-203, nota 5; Băluță 1983, 72, 75, nota 13; Băluţă 1996, 101, nr. cat. 55; Gaiu 2010, 223-228, 223, nr. cat. 24, pl. IV/24; 224, nr. cat. 32, pl. V/32; 225, nr. cat. 34-35, pl. VI/34-35; 225, nr. cat. 39, pl. VI/39; 226, nr. cat. 48, pl. VII/48; 226-227, nr. cat. 50-51, pl. VII/50-51; 223 nr. cat. 57, pl. IV/57; 228, nr. cat. 60, pl. IV/60; nr. cat. 62, pl. IX/62; nr. cat. 67-69, pl. IX/67-69.

${ }^{258}$ Russu 1962, 469; Mitrofan 1964, 201, fig. 3/2.

${ }^{259}$ CIL III, 8076, 16, d; Gostar 1961, 164, nr. cat. 215-216; Băluţă 1983, 72, pl. CIV/5, CVII/ 29;CVIII/9; Gudea 1989, 447, 449, 453, nr. cat. 1, 3, 6, 9, 24, două opaițe fără număr de catalog, pl. IX/1, 3, 6, X/9, XI/24; Băluță 1996, 102, nr. cat. 64; Roman 2006, 64-65, 116-118, 129-133, nr. cat. 77, 102, 104, 107-109, 142, 145-149, 151, 154, pl. 9/77,pl. 13/102, 108, pl. 14/77, 104, 142, 145-149, 151, 154, pl. 18/77, pl. 20/104, 109, pl21/142, 146-149, 151; Matei et alii 2006,57, 59-67, nr. cat. 52, 58, 60-62, 64, 67-72, 74-75, 77-78, pl. 52, 58, 61, 62a-b, 64, 68-72, 74-75, 77-78.

${ }^{260}$ CIL III 1634, 7d; CIL III 8076, 16e; Neigebaur 1851, 204, nr. cat. 31; Ackner, Müller 1865, 148, nr. 698, 3; Gostar 1961, 163-164, nr. cat. 210-214; Băluță 1961, 202-203, nota 5; Russu 1962, 469; Bajusz 1980, 372, 385-386, nr. cat. 
Romita $^{261}$, Samum $^{262}$. De asemenea, sunt menționate 10 exemplare: unele din Transilvania, făă loc de proveniență cert, ${ }^{263}$ altele cu proveniență necunoscutăă ${ }^{264}$. Un exemplar provine, probabil, de la Aquincum $^{265}$.

În castrul de la Micia au fost descoperite șase opaițe purtând marca FORTIS, toate încadrate în tipul Loeschcke X (PI. IX/9, Pl. X/10-14). În urma observaţiilor întreprinse asupra pastei, a modului de finisare a pieselor și asupra grafiei ștampilei, patru dintre acestea sunt atribuite de către noi, unor ateliere nord-italice (nr. cat. 25, 26, 28, 30) și două (nr. cat. 27 și 29), unor ateliere provinciale (Dacia Superior).

\section{IANVARI}

Officina producătorului Ianuarius a funcționat în nordul Peninsulei Italice, începându-și activitatea în a doua jumătate a secolului al II-lea p. Chr. ${ }^{266}$ În provinciile dacice lămpile cu ştampila acestui producător sunt repertoriate în număr de 70 de exemplare, fiind cunoscute opt forme de redare a acestei sstampile ${ }^{267}$. Astfel de lămpi au fost descoperite în Dacia Superior la Apulum $^{268}$, Boteș-Corabia ${ }^{269}$, Micia ${ }^{270}$, Ulpia Traiana Sarmizegetusa ${ }^{271}$, Tibiscum ${ }^{272}$, în Dacia Inferior la Cioroiu Nou $(\text { Aquae })^{273}$, Corabia ${ }^{274}$, Corpadea ${ }^{275}$, Dierna ${ }^{276}$, Drobeta ${ }^{277}$, Orlea ${ }^{278}$, Orșova $^{279}$, Răcari ${ }^{280}$, Slăveni ${ }^{281}$, Sucidava ${ }^{282}$, Romula ${ }^{283}$, în Dacia Porolissensis la Gilău ${ }^{284}$, Napoca $^{285}$ Potaissa $^{286}$, Porolissum $^{287}$, Șimleul Silvaniei ${ }^{288}$ și loc necunoscut ${ }^{289}$.

122, 732,769; Băluță 1989, 251-252, nr. cat. 48, pl. VI/1; Bărbulescu 1994, 127, fig. 23/1; Cătinaș 1996, 68, nr. cat. 10-13, fig. 3/10-13; Băluță 1996, 102, nr. cat. 62-63; Cătinaș 2004, 87-89, fig. 11.

${ }^{261}$ Matei et alii 2006, 67, pl. 76; Matei, Bajusz 1997, 233, pl. LXXIX/2.

${ }^{262}$ Roman 2006, 115-117, 129, nr. cat. 101, 105, 140-141, pl. XIII/101, 105,140 pl. XIV/141, pl. XIX/101, pl. XXI/141; Isac 2003, 154, 261, pl. XXIII/5.

${ }^{263}$ CIL III 1634, 7/b-c, CIL III, 8076, 16,1; Gostar 1961, 165, nr. cat. 253-258, 260; Băluță 1961, 202-203, nota 5, Băluță 1977, 220, nr. cat. 24; Băluță 1989, 251, nr. cat. 52, pl. VI/3.

${ }^{264}$ Tocilescu 1902, 373-374; Topoleanu 2010, 176-177, nr. cat. 7, 9, pl. II/7, pl. III/9; Zăgreanu 2011, 170, nr. cat. 4, pl. $2 / 4$.

${ }^{265}$ Zăgreanu 2011, 169, nr. cat. 1, pl. 1/1.

${ }^{266}$ Loeschcke 1919, 296; Bailey 1980, 96.

${ }^{267}$ Gostar 1961, 183.

${ }^{268}$ Gostar 1961, 165, nr. cat. 264, fig. 13; Băluță 1961, 207, nr. XXI, 1-5, pl. VI/3,8; IDR III/6, 204-206, nr. cat. 389, 389a; Russu 1962, 469; Băluță 1983, 79-81, pl. LXXXIII, 1a-b, LXXXIV/1 a-b, CVIII/26, CIX/4; IDR III/6, nr. cat. 389, 389a, fig. 386, 386a, Băluță 2003, 105-109, nr. cat. 1-5

${ }^{269}$ Băluță 1961, 207, nota 3, CIL III 8076, 18 c, Gostar 1961, 165, nr. cat. 269; Lipovan 1982-1983, 230.

${ }^{270}$ CIL III, 8076, 18 b; Gostar 1961, 165, nr. cat. 270; Băluță 1961, 207, nota 3, Băluță 1977, 214, 220, nr. cat. 30, pl. III/23a-b; Băluță 1983, 79, pl. LXXXIII/3a-b și CIX/5; Lychnus et Lampas 2006, 72, nr. cat. 197, pl. $125 / 197$ (voce Adriana Isac)

${ }^{271}$ CIL III 1634,10; Neigebaur 1851, 45, nr. cat. 230; Ackner, Müller 1865, 46, nr. cat. 191; Gostar 1961, 165, nr. cat. 262-263; Alicu 1985, 85, pl. III, IV, VI; Alicu 1976, 214-215, nr. cat. 70-77, pl. 2/26-32, 4/4-8; Alicu 1979, 240, nr. cat. 22; Alicu 1994, 25-27, 155, 157-158, 164-165, 167, 174, 180-181, 192, 194, nr. cat. 70-71, 93, 102, 258, 261262, 295, 383-384, 537, 770, 776, 1158-1168, 1246, fig. 3-5/70-71, 93, 384, fig. 17/70-71, 93, 102, 261-262, 295, 384, 537 ,770, 1158-1168, fig. 22-23, 24, pl. 2/71, 93, pl. 5/384, pl. 17/770, pl. 28/1158-1166; Lychnus et Lampas 2006, 69, 77, nr. cat. 177, 230, pl. 122/177, pl. 130/230 (voce Adriana Isac); Alicu 2006, 21-23, 76-77, 80-81, 84, 93, 94, 100, 128, 143-144, 180-182, 188, Kat. 70-71, 93, 102, 258, 261-262, 295, 383-384, 537, 770, 776, 1158-1168, Taf. II/70, III/71, V/93, VI/102, 384, XII/537, XV/770, XXIV/1158-1160, XXV/1161-1166; Höpken, Fiedler 2008, 148, pl. 111/13d.

${ }^{272}$ Benea 1990, 149, 164, nr. cat. 74-75, fig. 8/75, 16/74a-b; Regep 2001, 84-85, nr. cat. 5, pl. I/3.

${ }^{273}$ Gostar 1961, 165, nr. cat. 272; IDR II, 155; Tudor 1978, 91; Bondoc 2008, 54-55, nr. cat. 6-7, 17/6-7.

274 IDR II, 321; Tudor 1978, 91.

${ }^{275}$ Băluță 1996, 103, nr. cat. 68, pl. V/6 și XIII/9; Pop 1970, 160, nr. 18, fig. $3 / 4$ (greu lizibilă).

${ }^{276}$ Băluță 1961, 207, nota 3; Băluță 1996, 102, nota 51.

${ }^{277}$ Bărcăcilă 1932, 245, nr. cat. 2, fig. 12; Florescu 1933, 51, nr. 13, fig. 10/1; Gostar 1961, 165, nr. cat. 265; Tudor 1978, 91; IDR II, 124; Cristescu 2004, 68.

${ }^{278}$ IDR II, 314; Tudor 1978, 91; Gherghe, Cojoc 2011, 77, nr. cat. 71, pl. 13/68.

${ }^{279}$ Băluță 1961, 207, nota 3 .

${ }^{280}$ Gostar 1961, 165, nr. 271; Băluță 1961, 207, nota 3; Tudor 1978, 91; IDR II, 170.

${ }^{281}$ Popilian 1971, 636, fig. 7/1, 3; Tudor 1978, 92; IDR II, 545; Bondoc 2012, 37, fig. 6-9.

${ }^{282}$ Gherghe, Negru 2008, 88, nr. cat. 5, pl. 34/5; Gherghe, Cojoc 2011, 77-78, nr. cat. 72-74, pl. 13/69, pl. 14/70-71. 
În castrul de la Micia a fost descoperit un opait de tipul Loeschcke X (nr. cat. 31) din a cărui ștampilă se păstrează literele IA (PI. X/15). Ornamentul de pe bordură, linii incizate în formă de rețea, devine un argument cert, credem noi, conform căruia piesa în discuție este un produs al unor ateliere provinciale. În urma consultării unei vaste bibliografii, acest decor pare a fi unul specific provinciilor dacice, poate chiar exclusiv provinciei Dacia Superior (?).

\section{MIA}

O lucernă care se găsește la Kunsthistorisches Museum Wien, cu ştampila M. IVNIV AESCINVS ar permite completarea iniţialelor acestui producător purtând tria nomina. Numele său poate fi M(arcus) I(unius) A(escinus) ${ }^{290}$. Officina producătorului cu iniţialele MIA este activă la începutul secolului al II-lea p. Chr. în Italia septentrională ${ }^{291}$. În zona intracarpatică sunt repertoriate trei exemplare având imprimată această marcă. Piesele au fost descoperite în Dacia Superior, două la Apulum $^{292}$, și una la Cristești ${ }^{293}$.

În castrul de la Micia a fost descoperit un singur exemplar (nr. cat. 32), încadrat în tipul Loeschcke X, având înscrisă pe bază ștampila MIA (Pl. X/16). Calitatea superioară a pastei, aspectul general îngrijit al piesei, grafia ștampilei, precum și raritatea mărcii sunt elemente care ne determină să atribuim acest opaiț unui atelier nord-italic.

\section{OPTATI}

Officina producătorului Optatus este localizată în nordul Peninsulei Italice ${ }^{294}$. Piesele acestui meşter sunt răspândite în multe provincii ale Imperiului Roman. În provinciile dacice sunt repertoriate 23 de exemplare ce poartă ștampila acestui producător, în Dacia Superior, la Alburnus Maior $^{295}$, Boteș-Corabia ${ }^{296}$, Apulum ${ }^{297}$, Dierna ${ }^{298}$, Ghelari ${ }^{299}$, Micia $^{300}$, Ulpia Traiana

${ }^{283}$ Tudor 1937, 121, nr. cat. 316 fig. 55 a, 58 k; Gostar 1961, 165, nr. 266-267; Tudor 1978, 89, 91, fig. 23/5; IDR II, 445; Cristescu 2004, 68.

${ }^{284}$ Isac, Roman 2001, 374, nr. cat. 30, pl. V/30a-b, VII/30b.

${ }^{285}$ Băluță 1961, 207, nota 3; Russu 1962, 469; Băluță 1983, 79, pl. CIX/8; Băluță 1996, 103, nr. cat. 69, pl. XIII/8.

${ }^{286}$ CIL III 8076, 18a; Gostar 1961, 165, nr. cat. 268; Băluță 1961, 201, nota 3; Mitrofan 1969, 519, fig. 4; Băluță 1996, 102-103, nr. cat. 67, pl. IX, Cătinaș 1996, 64-65, 68, nr. cat. 14, fig. 3/14, Cătinaș 2004, 88, fig. 12.

${ }^{287}$ Gudea 1996, 202, nr. cat. 1, pl. XLVIII/1.

${ }^{288}$ Lychnus et Lampas 2006, 88, nr. cat. 300, pl. 141/300 (voce Cristian Aurel Roman); Băluță 1979, 169, pl. IV/1; Antique Bronzes in Romania, 160, nr. cat. 272 (voce Cristian Aurel Roman).

${ }^{289}$ Gostar 1961, 166, nr. cat. 273-275; Băluță 1996, 102, nota 51; Topoleanu 2010, 165-167, 177, nr. cat. 10-11, pl. III/10-11; Topoleanu 2012, 74-76, 88-90, nr. cat. 34-35,pl. V/34-35, pl. XX/34-35.

${ }^{290}$ Buchi 1975, 104.

${ }^{291}$ Loeschcke 1919, 296.

292 IDR III/6, 387, fig. 384, Băluță 1961, 210, nr. cat. XXIX, 1, pl. VIII/1; Russu 1962, 470; Băluță 1983, 87, pl. LXXXVII/10a-b, CX/22; IDR III/6, 387; Băluță 2003, 105, nr. cat. XXXVIII, 1-2.

${ }^{293}$ Gostar 1961, 167, 194, nr. cat. 313, fig. 12; Russu 1962, 470; Băluță 1983, 87, LXXXVII/9, CX/18; Man 2011, 187, pl. CXXXIV/56.

${ }^{294}$ Loeschcke 1919, 297.

${ }^{295}$ Neagu, Bocan 2007-2008, 98, nr. cat. 13, pl. 5/13; Bocan, Ursuțiu, Cociș 2007-2008, 207-208, 211-212, nr. cat. $37-$ 40, pl. 5/37-40; Bocan, Ursuțiu, Cociș 2008, 45, 48-49, nr. cat. 37-40, pl. 15/37, 16/38-40; Alburnus Maior III, 15, nr. cat. 2 , pl. 56/2, 117, nr. cat. 1, pl. 77/1, 148, nr. cat. 2, pl.122/2, 215, nr. cat. 1, 263/1, 117, nr. cat. 1, pl. 77/1.

${ }^{296}$ CIL III, 8076, 26 c (publicată ca fiind din Zlatna); Gostar 1961, 168-169, nr. 354-356 (publicate ca fiind din Ampelum); Băluță 1961, 212, nota 2; Lipovan 1982-1983, 230; Băluță 1983, 93, nota 6;

${ }^{297}$ CIL III, 8076, 26 a; Gostar 1961, 168, nr. cat. 350-351, Băluță 1961, 212, nr.. XXXII, 1, 2; Băluță 1983, 93, nota 4; Băluță 1999, nr. cat. 401, fig. 398, Băluță 2003, 142-144, nr. cat. 1-3.

${ }^{298}$ Băluță 1983, 93, nota 8; Russu 1962, 470.

${ }^{299}$ Gostar 1961, 169, nr. cat. 360; Băluță 1983, 93.

300 CIL III, 8076, 26b; Daicoviciu 1930-1931, 43; Gostar 1961, 169, nr. cat. 357-358; Băluță 1961, 212, nota 2; Băluță 1983,93 , nota 5 . 
Sarmizegetusa $a^{301}$, în Dacia Porolissensis la Napoca ${ }^{302}$, Potaissa ${ }^{303}$, Porolissum ${ }^{304}$, precum și Pancevo $^{305}$. De asemenea, mai este menționat un exemplar având loc de proveniență necunoscut, probabil din Transilvania ${ }^{306}$.

În castrul de la Micia a fost descoperit un opaiț (nr. cat. 33), încadrat în tipul Loeschcke X, purtând ștampila OPTATI (PI. X/17). În urma observațiilor întreprinse asupra aspectului pastei, a modului neîngrijit de finisare a piesei și a imperfecțiunilor ștampilei, această piesă poate fi atribuită unui atelier provincial.

\section{STROBILI}

Producătorul Strobilius, despre care se crede că a emigrat din Egipt ${ }^{307}$, şi-a început activitatea într-o officina localizată în Gallia Cispadana, la Gazzoli, pe teritoriul oraşului actual Modena $^{308}$.

Piesele acestui producător sunt răspândite în multe din provinciile Imperiului Roman. În provinciile dacice au fost repertoriate 46 de exemplare ce poartă ștampila acestui meșter, în Dacia Superior, la Ampelum ${ }^{309}$, Alburnus Maior ${ }^{310}$, Apulum $^{311}$, Cristeşti $^{312}$, Micia $^{313}$, Sebeş ${ }^{314}$, Tibiscum $^{315}$ şi Ulpia Traiana Sarmizegetusa ${ }^{316}$, în Dacia Inferior la Romula ${ }^{317}$ și Slăveni ${ }^{318}$ şi în Dacia Porolissensis la Napoca $^{319}$ și Potaissa ${ }^{320}$. De asemenea, este menționat un exemplar al cărui loc de proveniență este necunoscut ${ }^{321}$.

În castrul de la Micia a fost descoperit un opaiț (nr. cat. 34), de tip Loeschcke X purtând ştampila STROBILI (PI. X/18). Calitatea superioară a pastei, aspectul general îngrijit al piesei, grafia ștampilei sunt argumente care ne determină să atribuim acest opaiț unui atelier nord-italic.

${ }^{301}$ Lychnus et Lampas 2006, 80, nr. cat. 253, pl. 133/253 (voce Adriana Isac).

302 Gostar 1961, 168, nr. cat. 352; Băluță 1983, 93,

${ }^{303}$ Gostar 1961, 168, nr. cat. 353; Băluță 1961, 212, nota 2, Băluță 1983, 93, pl. CX/1, CXI, 27, Cătinaș 1996, 65-66, 68, nr. cat. 17 , fig. 4

${ }^{304}$ Roman 2006, 135, nr. cat. 163, pl. 14/163.

305 Gostar 1961, 169, 359; Băluță 1983, 93, nota 9.

${ }^{306}$ Gostar 1961,169, nr. cat. 36; Băluță 1983, 93-94, nota 11

${ }^{307}$ Loeschcke 1919, 286, 288.

${ }^{308}$ Loeschcke 1919, 288, 289, 296.

${ }^{309}$ Lipovan 1988, 185, 187, nr. cat. V/1.

${ }^{310}$ Bocan, Ursuțiu, Cociș 2007-2008, 208, 212, nr. cat. 41-42, pl. 5/41-42; Alburnus Maior III, 182,199, nr. cat. 1, pl. 183/1, nr. cat. 12, pl. 122/12; Bocan, Ursuțiu, Cociș 2008, 45-46, 49, nr. cat. 41-42, pl. 16/41-42.

311 CIL III, 8076, 29a (cf. = 1634, 9, a); Neigebauer 1851, 165, nr. cat. 333; Ackner, Müller 1865, 112, nr. cat. 538, 3; Băluță 1961, 214-215, nr. cat. XXXV, 1-12, Gostar 1961, 170-171, nr. 400-415; pl. IX/2-8, pl. X/1-2, XII/4-5; IDR III/6, 410, fig. 407; Băluță 1983, 100-102, pl. XCII/5-12, XCIII, 1-6, CXII, 19-21, CXIII, 1-6, 10-14; Băluță 1989, 254, nr. cat. 59-60, pl. VI/4,7; Băluță 2003, 162-168, nr. LXX/ 1-18.

312 Băluță 1961, 214, nota 2; Gostar 1961, 171, nr. 420-424; Băluţă 1983, 100, pl. CXII/25, XCIII/7.

${ }^{313}$ Băluță 1983, 100, pl. CXII/24.

314 Băluţă 1989, 254, nr. cat. 61, pl. VI/6.

${ }^{315}$ Benea 1990, 165, nr. 82.

${ }^{316}$ Daicoviciu 1924, 256, nr. cat. 164; Daicoviciu, Floca 1937, 13-14, fig. 10 A; Gostar 1961, 170, 397-398; Alicu 1976, 217, nr. cat. 92-95, pl. 2/45-46, 5/7; Băluță 1977, 221, nr. cat. 34, pl. III, 24 a-b; Alicu 1994, 32, 175, 193, 195, nr. cat. 552-556, 1179, 1184, 1249-1250, fig. 19/ 552-555, 1179, 1184, pl. 15/555, pl. 30/1184; Alicu 2006, 27-28, 131132, 184-186,189, Kat. 552-556, 1179, 1184, 1249-1250, Taf. XIII/555, XXV/1184; Lychnus et Lampas 2006, 82, nr. cat. 264, pl. 135/264 (voce Adriana Isac).

${ }^{317}$ Băluță 1961, 214, nota 2; Gostar 1961, 171, nr. cat. 417; IDR II, 452-453; Tudor 1937, 121, nr. cat. 318; Tudor 1978, 92.

${ }^{318}$ Bondoc 2012, 37, fig. 11.

${ }^{319}$ Gostar 1961, 171, nr. 416; Băluță 1983, 100; Băluţă 1996, 107, nr. 86.

${ }^{320}$ CIL III 16349 b; Neigebauer 1851, 204, nr. cat. 31; Ackner, Müller 1865, 148, 698/2, Băluță 1961, 214, nota 2; Gostar 1961, 171, nr. 418-419; Băluță 1983, 100, pl. XCIV/1 și CXII/23; Băluţă 1996, 107, nr. cat. 85, pl. IX/4; Cătinaş 1996, 66, 68, nr. 20-21, fig. 5/20-21.

${ }^{321}$ CIL III, 8076, 29 b; Gostar 1961, 171, 425; Băluță 1996, 108, nr. cat. 87. 


\section{ȘTAMPILE ILIZIBILE}

În colecțiile Muzeului Național de Istorie a României se află un opaiț (nr. cat. 35), provenit din castrul de la Micia cu ștampilă ilizibilă. În urma observațiilor întreprinse asupra aspectului pastei, a modului neîngrijit de finisare, această piesă este atribuită unui atelier local, din așezarea de la Micia.

\section{Lămpi tubulare, încadrabile în tipul Alicu XI}

Acest tip de lămpi se caracterizează prin rezervorul de formă atât circulară, cât și tubulară. Opaițele din acest tip sunt prevăzute cu multe orificii de ardere. Ciocul este scurt, ușor ieșit în afară.

În castrul de la Micia a fost descoperit un exemplar (nr. cat. 93), fragmentar, produs probabil, într-un atelier provincial. Nu excludem posibilitatea ca acest opaiț să fi fost confecționat chiar la Micia. Deși păstrează doar un orificiu de ardere, forma sa poate fi ușor reconstituită. Astfel, piesa este asemănătoare cu două exemplare, descoperite la Ulpia Traiana Sarmizegetusa ${ }^{322}$. Un alt opaiț asemănător a fost descoperit în castrul de la Gilău ${ }^{323}$. De asemenea, un exemplar apropiat morfologic de acest opaiț provine de la Ószőny în Pannonia ${ }^{324}$.

\section{CONSIDERAȚII}

Muzeul Național de Istorie a României este depozitarul unei importante colecții de instrumente antice de iluminat provenită din castrul roman de la Micia, alcătuită din 110 opaiţe și valva superioară a unui tipar pentru opaițe. Această colecție de lămpi nu se evidențiază printr-o varietate tipologică deosebită, dar este remarcabilă prin valoarea sa documentară și muzeistică. Astfel, se pot distinge șase tipuri de lămpi: Loeschcke IV (un exemplar: nr. cat. 1), Loeschcke VIII (opt exemplare: nr. cat. 2-9), Loeschcke IX (patru exemplare: nr. cat. 14-17), Loeschcke X (52 de exemplare: nr. cat. 18-69), Iványi IX (patru exemplare: nr. cat. 10-13) și Alicu XI (un exemplar: nr. cat. 94). De asemenea, 24 de exemplare (nr. cat. 70-93) au fost încadrate în tipul Firmalampen, iar 16 lămpi (nr. cat. 95-110), din care se păstrează fragmente de dimensiuni reduse și neconcludente din punct de vedere morfologic, nu au putut fi încadrate tipologic. În acest studiu a fost analizat și un fragment din valva superioară a unui tipar de opaițe (nr. cat. 111). Acesta a fost conceput pentru confecționarea unor opaițe de tip Loeschcke IX, însă se poate afirma, cu certitudine, faptul că este un rebut, spațiile pentru canal și bordură fiind greșit realizate.

În cadrul celor 110 lămpi analizate în acest studiu se individualizează un număr de 80 de opaițe, care aparțin tipului cunoscut în literatura de specialitate sub denumirea de Firmalampen. În urma acestei analize s-a constatat faptul că un număr de 19 opaițe poartă ștampila unor producători: APRIO (un exemplar: nr. cat. 18 - tip Loeschcke X); ATIMETI (3 exemplare: nr. cat. 14 - tip Loeschcke IX, nr. cat. 19-20 - tip Loeschcke X); CAI (un exemplar: nr. cat. 21 - tip Loeschcke X); CAMPILI (două exemplare: nr. cat. 22-23 - tip Loeschcke X); FESTI (un exemplar, nr. cat. 24 - tip Loeschcke X); FORTIS (șase exemplare: nr. cat. 25-30 - tip Loeschcke X); IANVARI (un exemplar: nr. cat. 31 - tip Loeschcke X); MIA (un exemplar: nr. cat. 32 - tip Loeschcke X); OPTATI (un exemplar: nr. cat. 33- tip Loeschcke X); STROBILI (un exemplar: nr. cat. 34 - tip Loeschcke X). De asemenea, un exemplar (nr. cat. 35) nu a putut fi citit, având ștampilă ilizibilă.

\footnotetext{
${ }^{322}$ Alicu 2006, 152-153, Kat. 998-999, Taf. XVIII/998; Lychnus et Lampas 2006, 73, nr. cat. 203, fig. 203 (voce Adriana Isac).

${ }^{323}$ Isac, Roman 2001, 371, nr. cat. 13, pl. II/13; Roman 2006, 90, nr. cat. 32, pl. 7/32.

${ }^{324}$ Iványi 1935, 288, nr. cat. 4096, pl. LV/7.
} 
După cucerirea Daciei de către romani, în noua provincie pătrund majoritatea produselor aflate în uz la acea dată. Este și cazul opaițelor, printre acestea evidențiindu-se importuri provenind din mediul nord-italic, din Pannonia sau chiar din Moesia Inferior ${ }^{325}$. Odată cu creșterea populației provinciei și deci, în același timp și a cererii, atelierele locale au trecut la imitarea acestor produse de serie, fenomen similar cu cel din alte provincii ale Imperiului Roman şi, poate acest fenomen a determinat chiar apariția unor filiale locale ale atelierelor nord-italice. Lipsa unor analize fizicochimice condiționează argumentația conform căreia produsele aparțin atelierelor nord-italice, unor filiale ale atelierelor originare din Italia septentrională sau sunt simple copii locale. $\mathrm{Cu}$ toate acestea, în cazul opaițelor, atribuirea se poate realiza în urma unor examinări vizuale ce au la bază calitatea grafiei ștampilei (în cazul opaițelor de tip Firmalampen), aspectul pastei, modalitatea de finisare, anumite tipuri de decor, unele imperfecțiuni sesizate în execuția pieselor și cele mai apropiate analogii. Astfel, pe baza acestor criterii, putem afirma faptul că instrumentele de iluminat analizate în acest studiu se pot grupa după cum urmează:

I. Importuri nord-italice (lămpi atribuite unor ateliere din nordul Peninsulei Italice -21 de exemplare: nr. cat. 4, 18, 22-26, 28, 30, 32, 34, 41, 50, 56, 58, 63, 65-67, 77, 91);

II. Importuri moesice (lămpi atribuite unor ateliere din provincia Moesia Inferior: Durostorum și altor centre de producție - trei exemplare: nr. cat. 1, 5, 107);

III. Produse provinciale (lămpi atribuite unor ateliere din provincia Dacia Superior (63 de exemplare): Ampelum (două exemplare: nr. cat. 98, 104), Apulum (patru exemplare: nr. cat. 14-16, 19), Ulpia Traiana Sarmizegetusa (patru exemplare: nr. cat. 10-13) și altor centre de producție (53 de exemplare: nr. cat. 3, 8, 20-21, 27, 29, 31, 33, 38, 40, 43-44, 48, 51-55, 59-62, 64, 68-72, 7475, 78, 82-90, 92-97, 99-101, 105-106, 109-110);

IV. Produse locale (lămpi atribuite unor ateliere din cadrul așezării de la Micia - 24 de exemplare: nr. cat. 2, 6-7, 9, 17, 35-37, 39, 42, 45-47, 49, 57, 73, 76, 79-81, 102-103, 108, 111).

Așezarea de la Micia este cunoscută în literatura de specialitate ca unul dintre centrele de producție ceramică, fapt întărit și de descoperirea a două tipare (valva superioară a unui tipar de opaițe și valva inferioară a unui tipar de statuete) ${ }^{326}$. Descoperirea acestor tipare mai sus menționate, coroborată cu cercetarea unui grup de cuptoare evidențiază existența unor ateliere de manufacturare a opaițelor în cadrul așezării romane de la Micia ${ }^{327}$. În urma analizei amănunțite a pieselor s-a constat o modalitate de realizare caracteristică atelierelor de la Micia la nivelul butonilor (butoni bifizi aplicați într-o manieră specifică, butoni circulari și butoni care pornesc direct din cordon). De asemenea, aspectul pastei coroborat cu modalitatea particulară de confecționare, mai sus amintită, unele imperfecțiuni de fabricație, retuşări neglijente, precum și maniera superficială de aplicare a firnisului, calitatea acestuia, pot fi argumente importante în stabilirea producției locale.

În ceea ce privește prezența unor noi tipuri de decoruri întâlnite exclusiv în provincia Dacia Superior (rețea de incizii și o combinație între rețea și incizii dispuse radial), putem emite următoarele concluzii: fie producătorii locali ornamentează astfel lămpile pentru a le diferenția de cele provenite din atelierele originare aparținând mediului nord-italic (ce poartă marca unor producători consacrați), fie decorurile sunt rezultatul imaginației producătorilor locali care se propagă, într-un anumit interval cronologic, numai la nivelul provinciei. Astfel, fără a modifica aspectul morfologic al opaițelor meșterii locali din provinciile dacice au îmbogățit repertoriul clasic al decorurilor.

Din punct de vedere cronologic se disting două direcții: importurile provenite din mediul nord-italic sau din Moesia Inferior sunt datate în secolul al II-lea p. Chr., în timp ce produsele provinciale și cele locale sunt încadrate cronologic pe parcursul secolelor II-III p. Chr.

\footnotetext{
325 Băluță 1989, 244.

326 Obiectele sunt inedite, aflându-se în colecțiile Muzeului Național de Istorie a României, București. Tiparul de opaiț este analizat în cadrul acestui studiu (nr. cat. 111).

${ }^{327}$ Floca, Ferenczi, Mărghitan 1970.
} 


\section{CATALOG $^{328}$}

\section{Lămpi de tip Loeschcke IV}

1. Opaiț de tip Loeschcke IV (fragment capac). PI. III/1. Nr. inv.: 131709. Micia 1976, castru, S I, carou 27. $\mathrm{Lp}^{329}=6,5 \mathrm{~cm} ; 1=5,4 \mathrm{~cm} ; \mathrm{hp}=1 \mathrm{~cm}$. Pastă fină (Munsell $10 \mathrm{YR}, 7 / 6$, yellow) ${ }^{330}$. Firnis parțial păstrat (Munsell $10 \mathrm{YR}, 5 / 6$, strong brown). Ardere primară completă. Tipar bivalv. Disc rotund, concav, cu un orificiu de alimentare în centru, delimitat de bordură printr-un cordon circular. Bordură lată. Cioc, probabil, cu un orificiu de ardere. Urmă de ansă pe bordură. Începutul secolului al II-lea p. Chr. Atelier Moesia Inferior, Durostorum (?). Inedit.

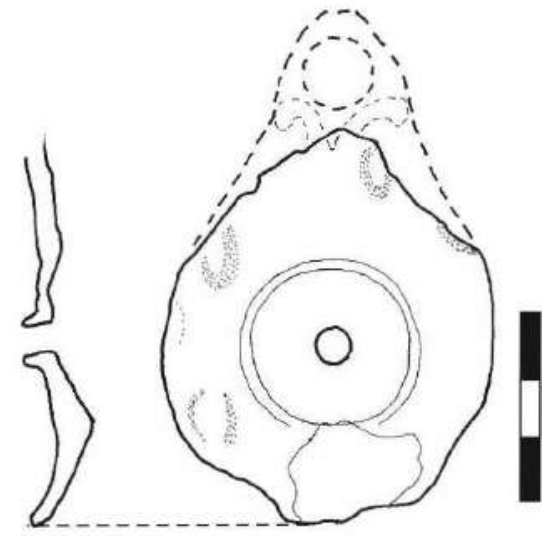

\section{Lămpi de tip Loeschcke VIII}

2. Opait, probabil de tip Loeschcke VIII (fragment din capac, rezervor și ansă). Pl. III/2. Nr. inv.: 338489. Micia 1985, castru, S XXVII, passim, $-0,70 \mathrm{~m}$. Lp = 3,7 cm; lp = 2,9 cm; hp = 2,8 cm. Pastă fină (Munsell 7.5 YR, 6/6 reddish yellow).

328 Pentru alcătuirea acestui catalog a fost utilizat criteriul tipologic. Astfel, succesiunea opaitelor în cadrul catalogului a fost stabilită în funcție de încadrarea acestora în tipologia realizată de Sigfried Loeschcke, pentru lămpile de la Vindonissa, în anul 1919. În cazul tipurilor de lămpi care nu se regăsesc în tipologia autorului mai sus menționat, acestea au fost încadrate în tipologiile realizate de Dora Iványi, pentru lămpile din Pannonia, în anul 1935, respectiv Dorin Alicu pentru lămpile de la Ulpia Traiana Sarmizegetusa, în anul 1994. Ordinea pieselor în cadrul tipurilor a fost stabilită în funcție de starea de fragmentaritate. Descrierea obiectelor a fost realizată urmarindu-se criteriile: denumire obiect; încadrare tipologică; starea de conservare, planșa/figura; număr inventar MNIR; contextul arheologic din care provin (informațiile marcate pe ambalaje sau chiar pe piese); dimensiuni; descrirea materialului din care au fost confectionate, precum și a tehnicii de realizare a acestora; descrierea elementelor morfologice; datare; provincia, localitatea sau zona geografică în care au fost confecționate; referințe bibliografice.

Desenele au fost realizate de doamna Simona Mateescu, iar fotografiile de domnul George Nica, le mulțumim pe acestă cale.

${ }^{329}$ Abrevieri utilizate: $\mathrm{S}=$ unitate de cercetare (secțiune); $\mathrm{L}=$ lungime; Lp = lungime păstrată; 1 = lățime; $1 p=$ lățime păstrată; $h$ = înălțime; $h p$ = înălțime păstrată.

${ }^{330}$ Pentru deteminarea culorii pastelor și a firnisului a fost utilizat Munsell 1994.
Firnis parțial păstrat (Munsell 2,5 YR, 4/6 dark red). Ardere primară incompletă. Tipar bivalv. Bordură parțial păstrată, lată, decorată cu două caneluri fine, circulare, concentrice. Rezervor rotund. Este prevăzut cu o ansă lamelară, bifidă, atașată pe bordură și rezervor. Sec. II p. Chr. Atelier local Micia (?). Inedit.

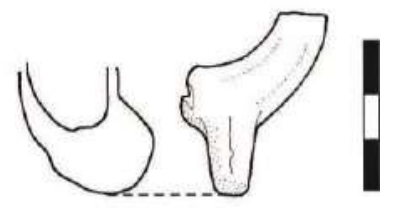

3. Opait, probabil de tip Loeschcke VIII (fragment din capac și rezervor, cu dimensiuni de 4,5 × 2,3 cm). Pl. III/3. Nr. inv.: 338490. Micia 1978, castru, TR; hp = 2,1 cm. Pastă fină (Munsell 5YR 6/6, reddish yellow). Firnis parțial păstrat (Munsell 5YR 5/6, yellowish red). Ardere primară incompletă. Tipar bivalv. Disc parţial păstrat, concav, ornamentat cu rozetă din care se păstrează patru lobi, delimitat de bordură printr-o canelură circulară. Bordură lată. Rezervor rotund. Sec. II p. Chr. Atelier provincial Dacia Superior (?). Inedit.

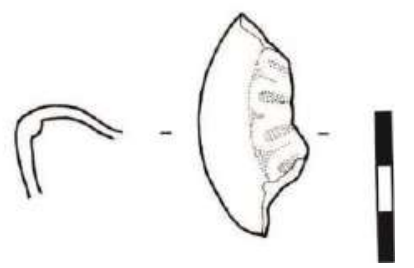

4. Opait polilychnis de tip Loeschcke VIII (fragmentar, se păstrează două fragmente din capac, cu dimensiuni de $6,5 \times 3,6 \mathrm{~cm})$. PI. III/ 4. Nr. inv.: 338488. Micia 1982, castru, S XXII, carou 2, $-1,25$ m. Pastă fină (Munsell 7.5YR 8/3, pink). Firnis parţial păstrat (Munsell 10R 4/6, red). Ardere primară completă. Ardere secundară pe ciocuri datorată utilizării. Tipar bivalv. Disc parțial păstrat, concav, ornamentat cu rozetă, delimitat de bordură printr-o bandă circulară de triunghiuri profilate. Bordură lată, prevăzută cu orificii de ventilație. Era prevăzut, probabil, cu cinci orificii de ardere, dintre care se păstrează două. Începutul secolului al II-lea p. Chr. Atelier nord-italic (?). Inedit.

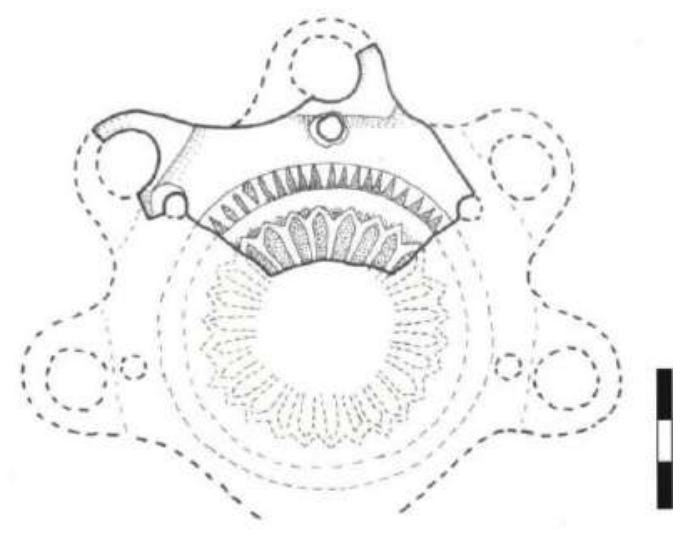


5. Opait, probabil de tip Loeschcke VIII (fragment din capac, cu dimensiuni de 5,6 × 4,4 cm). Pl. III/5. Fără nr. inv. Micia 1987, castru, S I b, carourile $12-13,-0,80 \mathrm{~m}$. Pastă fină (Munsell 10YR 6/4, light yellowish brown). Firnis parțial păstrat (Munsell 2.5YR 5/8, red). Ardere primară completă. Tipar bivalv. Disc parțial păstrat, rotund (?) concav, cu un orificiu de alimentare, decorat cu rozetă din care se păstrează şase lobi, delimitat de bordură printr-o profilatură, dublată de o canelură fină. Bordură lată. Sec. II p. Chr. Atelier Moesia Inferior (?). Inedit.

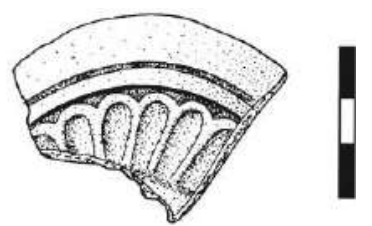

\section{Imitații de lămpi tip Loeschcke VIII}

6. Opaiţ lucrat la roată, imitație a tipului Loeschcke VIII (întregit). Pl. III/6. Nr. inv.: 124104. Micia 1976, castru, S I, carou 27, $-1,35 \mathrm{~m}$. $\mathrm{L}=8 \mathrm{~cm} ; 1=5,9 \mathrm{~cm} ; \mathrm{h}=3,8 \mathrm{~cm}$. Pastă fină (Munsell 7.5YR 8/3, red). Ardere primară completă. Ardere secundară pe cioc datorată utilizării. Roata olarului. Orificiu de alimentare larg, circular. Bordură îngustă, delimitată de rezervor printr-o canelură circulară. Cioc ușor tras în exterior. Rezervor circular. Bază inelară, cu un mic umbo în centru. Este prevăzut cu o ansă lamelară atașată pe rezervor. Începutul secolului al II-lea p. Chr. Atelier local Micia (?). Inedit.

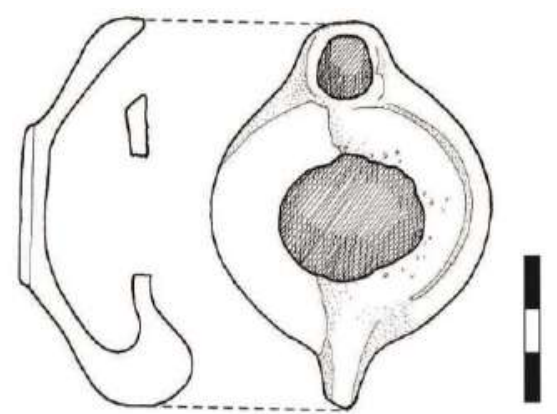

7. Opaiț lucrat la roată, imitație a tipului Loeschcke VIII (fragmentar, lipsesc mici fragmente din cioc și rezervor). Pl. III/7. Nr. inv.: 338487. Micia 1981, castru, S XVII, carou 7, $-1,30 \mathrm{~m}$. L = 7,5 cm; 1 $=5,1 \mathrm{~cm} ; \mathrm{h}=3,7 \mathrm{~cm}$. Pastă fină (Munsell 10YR 6/4, light yellowish brown). Firnis parțial păstrat (Munsell 10R 4/6, red). Ardere primară completă. Ardere secundară pe cioc datorată utilizării și pe bordură și rezervor în urma contactului cu o sursă de combustie. Roata olarului. Disc parţial păstrat, rotund, concav, delimitat de bordură printr-o canelură circulară. Bordură îngustă. Ciocul scurt, cu un orificiu de ardere, perforează o parte din bordură. Rezervor rotund. Bază inelară. Este prevăzut cu o ansă lamelară, atașată pe bordură și rezervor. Sec. II p. Chr. Atelier local Micia (?). Inedit.

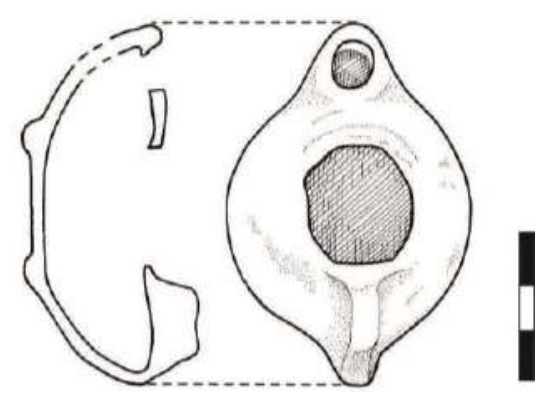

8. Opaiţ lucrat la roată, imitație a tipului Loeschcke VIII (fragmentar, lipsește toarta). PI. III/8. Nr. inv.: 139885. Micia 1976, castru, S I, carou 75, $1,25 \mathrm{~m} . \mathrm{L}=5,5 \mathrm{~cm} ; 1=4,6 \mathrm{~cm} ; \mathrm{hp}=2,6 \mathrm{~cm}$. Pastă fină (Munsell 5YR 6/4, light reddish brown). Firnis parțial păstrat (Munsell 5YR 6/8, reddish yellow). Ardere primară incompletă. Ardere secundară pe cioc datorată utilizării. Roata olarului. Disc rotund, concav, cu un orificiu de alimentare în centru. Bordură lată, decorată cu o retea de incizii. Ciocul scurt, cu un orificiu de ardere, perforează o parte din bordură. Rezervor rotund. Bază dreaptă, profilată. Urmă de ansă pe bordură şi rezervor. Începutul secolului al II-lea p. Chr. Atelier provincial Dacia Superior (?). Inedit.

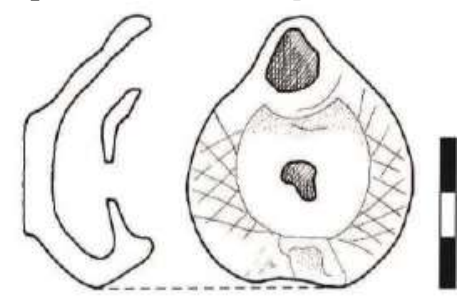

9. Opaiț trilychnis, lucrat la roată, imitație a tipului Loeschcke VIII (fragmentar, se păstrează un fragment din disc, ansă, rezervor şi bază și un fragment din cioc, cu două arzătoare). PI. III/9. Nr. inv. 338533 și 338536. Micia 1981, castru, S XIX, carou 2, lățire, $-0,60-0,65 \mathrm{~m}$. Lestimativă $=11,2 \mathrm{~cm}$; lestimativă $=7,2 \mathrm{~cm} ; \mathrm{hp}=5 \mathrm{~cm}$. Pastă fină (Munsell 5YR 6/6, reddish yellow). Ardere primară incompletă. Roata olarului. Disc parțial păstrat, rotund, ușor concav, ornamentat cu două cercuri concentrice incizate, cu un orificiu de alimentare în centru. Ciocul scurt, păstrează două orificii de ardere, care perforează bordura. Rezervor rotund. Bază dreaptă. Este prevăzut cu o ansă în formă de palmetă, decorată cu incizii radiale dispuse oblic. Sec. II p. Chr. Atelier local Micia (?). Inedit.

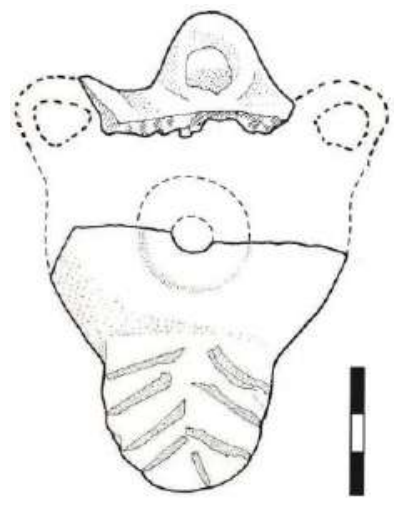




\section{Lămpi de tip IX Iványi}

10. Opaiț de tip IX Iványi (întreg). Pl. III/10. Nr. inv.: 131707. Micia 1977, castru, S II, carou 46, caseta 2, carou 2, $-0,90 \mathrm{~m} . \mathrm{L}=6,7 \mathrm{~cm} ; 1=8,2 \mathrm{~cm}$; $\mathrm{h}=3,5 \mathrm{~cm}$. Pastă fină (Munsell 7.5YR 6/4, light brown). Firnis parțial păstrat (Munsell 2.5YR 4/6, dark red). Ardere primară completă. Puternic ars secundar pe toată suprafața. Tipar bivalv. Capac dreptunghiular, plan, împărțit în două registre delimitate prin câte un cordon dreptunghiular. Fiecare registru este prevăzut cu un orificiu de alimentare. Bordură în formă de șnur. Cioc scurt, prevăzut cu cinci orificii de ardere bine delimitate între ele. Rezervor paralelipipedic. Bază dreaptă, delimitată prin două caneluri liniare pe trei dintre laturi și în formă de val pe latura dinspre cioc. Este prevăzut cu o ansă bogat decorată: câmpul toartei este împărțit în patru lobi, având la bază un buton aplatizat. Sec. II p. Chr. Atelier provincial Ulpia Traiana Sarmizegetusa (?). Inedit (piesa era cunoscută de Cloșca Băluță, care o amintește în lucrarea sa de doctorat - Băluță 1983, p. 13).

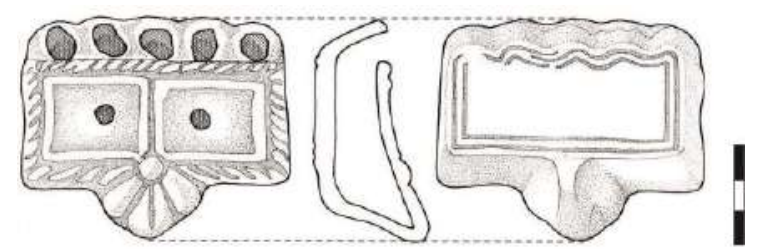

11. Opait de tip IX Iványi (fragmentar, se păstrează două fragmente din capac). PI. III/11. Nr. inv.: 157762. Micia 1980, castru, S III, carou 26, $0,75 \mathrm{~m} . \mathrm{Lp}=4,3 \mathrm{~cm} ; \mathrm{lp}=5,7 \mathrm{~cm} ; \mathrm{hp}=1,1 \mathrm{~cm}$. Pastă fină (Munsell 10YR 8/4, very pale brown). Firnis parțial păstrat (Munsell 2.5YR 5/8, red). Ardere primară completă. Ardere secundară pe cioc datorată utilizării. Tipar bivalv. Capac parțial păstrat, dreptunghiular, plan, delimitat de bordură printr-un cordon dreptunghiular (?). Bordura lată păstrează un buton aplatizat pe unul dintre colțuri. Ciocul scurt păstrează trei orificii de ardere. Sec. II p. Chr. Atelier provincial Ulpia Traiana Sarmizegetusa (?). Inedit.

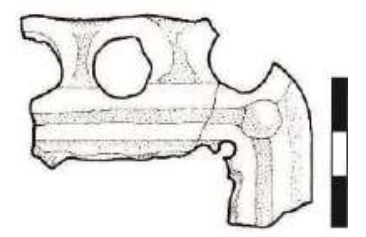

12. Opaiț de tip IX Iványi (fragment din bază cu rezervor, cu dimensiuni de $6 \times 2,4 \mathrm{~cm}$ ). PI. III/12. Nr. inv.: 338485. Micia 1976, castru, S I, carou 70,
$-0,80 \mathrm{~m} ; \mathrm{hp}=1,6 \mathrm{~cm}$. Pastă fină (Munsell 7.5 YR $7 / 6$, reddish yellow). Firnis parțial păstrat (Munsell 5 YR 4/4, reddish brown). Ardere primară completă. Tipar bivalv. Rezervor paralelipipedic. Bază dreaptă. Sec. II p. Chr. Atelier provincial Ulpia Traiana Sarmizegetusa (?). Inedit.

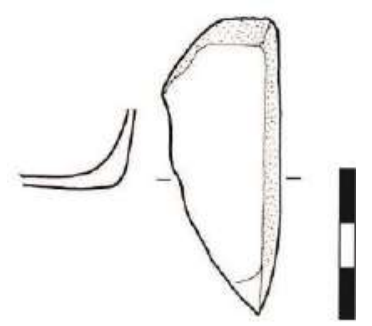

13. Opaiț de tip IX Iványi (fragment din cioc, rezervor şi bază, cu dimensiuni de $3,7 \times 2,6 \mathrm{~cm}$ ). PI. III/13. Nr. inv.: 338486. Micia 1976, castru, S I, carou $45,-0,70 \mathrm{~m} ; \mathrm{hp}=2,6 \mathrm{~cm}$. Pastă fină (Munsell 7.5 YR 7/6, reddish yellow). Firnis parțial păstrat (Munsell 5YR 4/6, yellowish red). Ardere primară incompletă. Ardere secundară pe cioc datorată utilizării. Tipar bivalv. Ciocul scurt păstrează două orificii de ardere bine delimitate între ele. Rezervor paralelipipedic. Bază dreaptă. Sec. II p. Chr. Atelier provincial Ulpia Traiana Sarmizegetusa (?). Inedit.

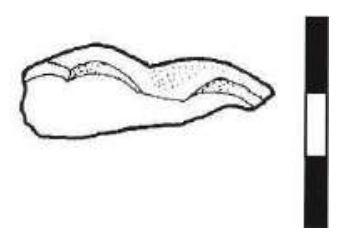

Lămpi epigrafice de tip Loeschcke IX

14. Opait de tip Loeschcke IX (fragmentar, lipsă partea superioară a ciocului și o parte din disc). PI. III/ 14; PI. IX/fig. 1. Nr. inv.: 131656. Micia 1977, castru, S II, carou 4, $-1,75 \mathrm{~m} . \mathrm{L}=9,2 \mathrm{~cm} ; 1=5,3$ $\mathrm{cm} ; \mathrm{h}=4,3 \mathrm{~cm}$. Pastă fină (Munsell $5 \mathrm{YR} 7 / 4$, pink). Firnis parțial păstrat (Munsell 5YR 6/8, reddish yellow). Ardere primară completă. Ardere secundară pe cioc datorată utilizării. Tipar bivalv. Disc parțial păstrat, rotund, concav, ornamentat cu rozetă cu opt lobi. Bordură lată, prevăzută cu doi butoni dispuși aproximativ simetric. Ciocul parțial păstrat, alungit, rotunjit, cu un un orificiu de ardere, era, probabil, străbătut longitudinal de un canal ușor adâncit, prevăzut cu un mic orificiu de ventilație. Rezervor tronconic. Baza ușor concavă, delimitată prin trei profilaturi puternic pronunțate are înscrisă în centru ștampila ATIMETI, în relief. Este prevăzut cu o ansă inelară, bifidă, ataşată pe bordură şi rezervor. Sec. II p. Chr. Atelier provincial Apulum (?). Referințe bibliografice: piesa era cunoscută de Cloșca Băluță, care o amintește în lucrarea sa de doctorat - Băluță 1983, 
p. 50, pl. XCI/13; Bocan, Neagu 2016, p. 543, no. 2 , fig. $2 / 2$.

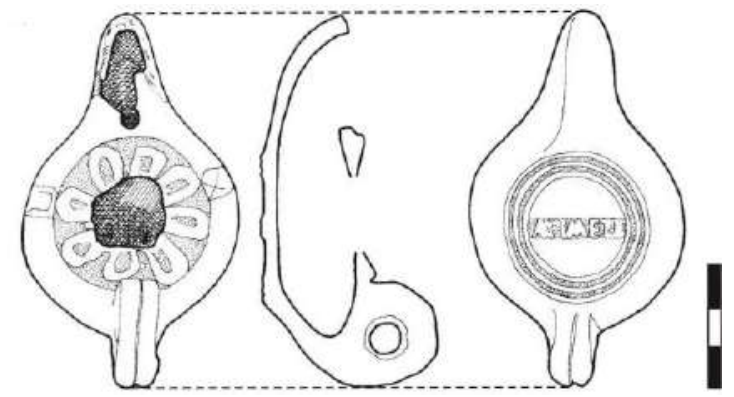

\section{Lămpi anepigrafice de tip Loeschcke IX}

15. Opait de tip Loeschcke IX (fragment capac). Pl. III/15. Nr. inv.: 124109. Micia 1976, castru, S I, carou 25, vegetal. $\mathrm{Lp}=6,8 \mathrm{~cm} ; \mathrm{lp}=4,7 \mathrm{~cm} ; \mathrm{hp}=$ $2,3 \mathrm{~cm}$. Pastă fină (Munsell 5YR 6/8, reddish yellow). Firnis parțial păstrat (Munsell 5YR 4/6, yellowish red). Ardere primară completă. Tipar bivalv. Disc concav, ornamentat cu rozetă cu opt lobi, prevăzut cu un orificiu de alimentare în centru. Bordura lată, decorată cu impresiuni dispuse, probabil, pe trei șiruri, este prevăzută cu doi butoni dispuși aproximativ simetric. Ciocul parțial păstrat, alungit (?) era, probabil, străbătut longitudinal de un canal ușor adâncit, prevăzut cu un mic orificiu de ventilație. Rezervor tronconic (?). Este prevăzut cu o ansă lamelară perforată, bifidă, atașată pe bordură. Sec. II p. Chr. Atelier provincial Apulum (?). Inedit.

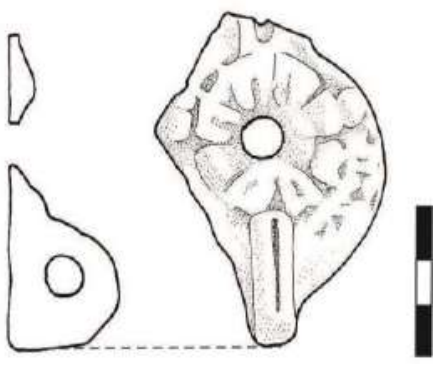

16. Opait, probabil, de tip Loeschcke IX (fragment din capac, ansă și rezervor). PI. III/16. Nr. inv.: 338491. Micia 1986, castru, S XXVIII, carou $13,-0,90 \mathrm{~m} . \mathrm{Lp}=5 \mathrm{~cm} ; \mathrm{lp}=4,3 \mathrm{~cm}$; hp = 3,5 cm. Pastă fină (Munsell 5YR 6/6, reddish yellow). Firnis parțial păstrat (Munsell 5YR 5/8, yellowish red). Ardere primară completă. Tipar bivalv. Disc parțial păstrat, concav, ornamentat cu rozetă care păstrează patru lobi. Bordură lată, parțial păstrată. Rezervor tronconic. Este prevăzut cu o ansă lamelară perforată, bifidă, atașată pe bordură și pe rezervor. Sec. II p. Chr. Atelier provincial Apulum (?). Inedit.

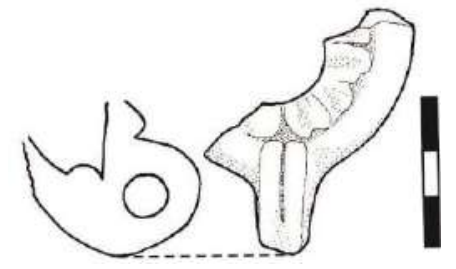

17. Opait, variantă a tipului Loeschcke IX (fragmentar, se păstrează capacul). Pl. III/17. Nr. inv.: 338502. Micia 1977, castru, SII, carou 74, $0,90 \mathrm{~m} . \mathrm{L}=6,2 \mathrm{~cm} ; 1=4,2 \mathrm{~cm} ; \mathrm{hp}=1,4 \mathrm{~cm}$. Pastă fină (Munsell 5YR 5/8, yellowish red). Ardere primară completă. Ardere secundară pe disc și bordură. Tipar bivalv. Disc rotund, mic, ușor concav, cu un orificiu de alimentare în centru, delimitat de bordură printr-un cordon circular. Bordură lată, puternic înclinată. Cioc alungit, bine delimitat, străbătut longitudinal de un canal lat, închis, cu un orificiu de ardere. Este prevăzut cu doi butoni amplasați simetric între cordon și canal. Sec. II p. Chr. Atelier local Micia (?). Inedit.

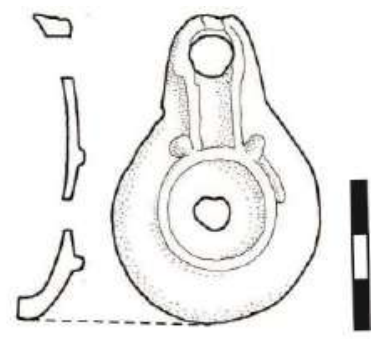

\section{Lămpi epigrafice de tip Loeschcke X}

18. Opait, probabil de tip Loeschcke $X$ (fragment din capac, rezervor și bază). Pl. IV/18; Pl. IX/fig. 2. Nr. inv.: 139893. Micia 1979, castru, S III, carou 58, $-0,90 \mathrm{~m} . \mathrm{Lp}=5,2 \mathrm{~cm} ; \mathrm{lp}=2,5 \mathrm{~cm} ; \mathrm{h}=3 \mathrm{~cm}$. Pastă fină (Munsell 5YR 7/4 pink). Firnis parțial păstrat (Munsell 7.5YR 6/8, reddish yellow). Ardere primară completă. Tipar bivalv. Disc parțial păstrat, rotund (?), neted, delimitat de bordură printr-un cordon. Bordura îngustă păstrează un buton. Rezervor tronconic. Baza ușor concavă, delimitată prin două caneluri concentrice, are înscrisă în centru ștampila [APRI]O (?), în relief. Sec. II p. Chr. Atelier norditalic (?). Referințe bibliografice: Bocan, Neagu 2016, p 543, no 1, fig. 2/1.
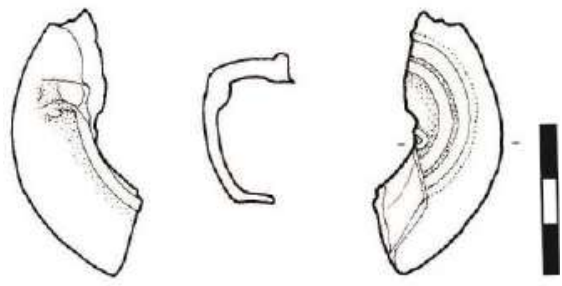

19. Opaiț de tip Loeschcke $X$ (fragmentar, lipsesc fragmente din disc, bordură și cioc). PI. IV/19; PI. IX/fig. 3. Nr. inv.: 176157. Micia 1981, castru, S XVIII, carou $16,-0,50 \mathrm{~m}$. Lp $=8,7 \mathrm{~cm} ; 1=5,4 \mathrm{~cm}$; h 
= 4,2 cm. Pastă fină (Munsell 5 YR 7/4, pink). Firnis parțial păstrat (Munsell 5YR 6/8, reddish yellow). Ardere primară completă. Ardere secundară pe cioc datorată utilizării. Tipar bivalv. Disc parțial păstrat, concav, probabil ornamentat cu rozetă, delimitat de bordură printr-un cordon care se îndreaptă spre cioc, îl înconjoară și formează un canal. Bordură lată, prevăzută cu doi butoni dispuși aproximativ simetric, decorată cu incizii radiale. Cioc alungit, rotunjit, cu un orificiu de ardere. Rezervor tronconic. Bază dreaptă. Ștampilă probabil ATIMETI (?). Este prevăzut cu o ansă inelară, bifidă, atașată pe bordură şi rezervor. Sec. II p. Chr. Atelier provincial Apulum (?). Referințe bibliografice: Bocan, Neagu 2016, p. 543 , no. 3 , fig. $2 / 3$.

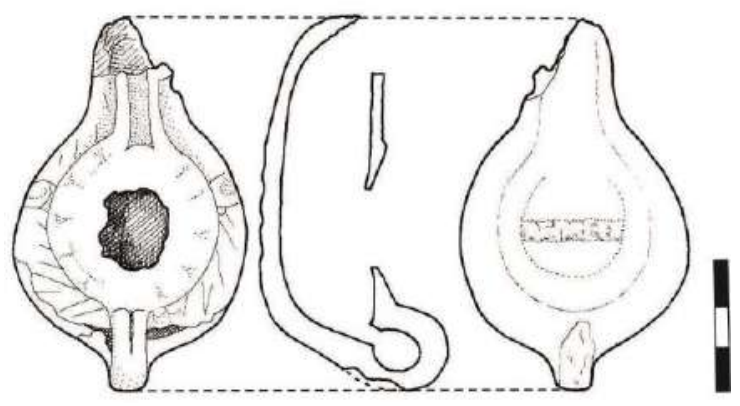

20. Opaiţ de tip Loeschcke X (întreg). PI. IV/20; Pl. IX/fig. 4. Nr. inv.: 131705. Micia 1976, castru, S I, carou 29, $-1,20 \mathrm{~m} . \mathrm{L}=6,4 \mathrm{~cm} ; 1=4,1 \mathrm{~cm} ; \mathrm{h}=$ $2,5 \mathrm{~cm}$. Pastă fină (Munsell 5YR 7/6, reddish yellow). Firnis parțial păstrat (Munsell 5YR 5/8, yellowish red). Ardere primară completă. Ardere secundară pe cioc, datorată utilizării. Tipar bivalv. Disc rotund, neted, cu un orificiu de alimentare în centru, delimitat de bordură printr-un cordon care se îndreaptă spre cioc, îl înconjoară și formează un canal prevăzut cu un mic orificiu de ventilație. Bordură îngustă, prevăzută cu doi butoni dispuși aproximativ simetric. Cioc alungit, rotunjit, cu un orificiu de ardere. Rezervor tronconic. Baza dreaptă, delimitată printr-o canelură fină, circulară are înscrisă în centru ștampila ATIMETI în relief. Sec. II p. Chr. Atelier provincial Dacia Superior (?). Referințe bibliografice: Bocan, Neagu 2016, p. 543 , no. 4 , fig. $2 / 4$.

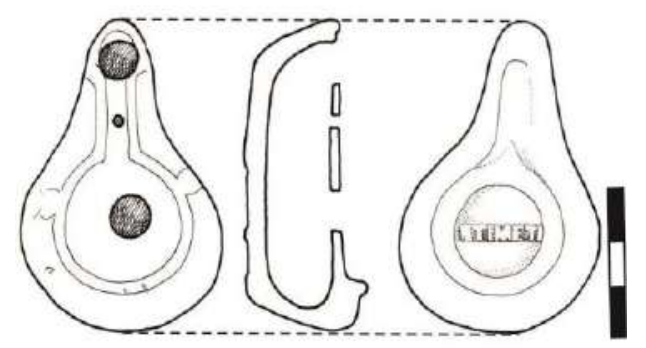

21. Opaiț de tip Loeschcke $X$ (întreg). Pl. IV/21; Pl. IX/fig. 5. Nr. inv.: 157729. Micia 1977, castru, S II. L = $7 \mathrm{~cm} ; 1=4,9 \mathrm{~cm} ; \mathrm{h}=2,4 \mathrm{~cm}$. Pastă fină
(Munsell 7.5YR 7/6, reddish yellow). Firnis parțial păstrat (Munsell 5YR 5/6, yellowish red). Ardere primară completă. Ardere secundară pe cioc, datorată utilizării. Tipar bivalv. Disc rotund, ușor concav, cu un orificiu de alimentare în centru, delimitat de bordură printr-un cordon proeminent care se îndreaptă spre cioc, îl înconjoară şi formează un canal prevăzut cu un mic orificiu de ventilație. Bordură prevăzută cu doi butoni dispuși aproximativ simetric. Cioc alungit, rotunjit, cu un orificiu de ardere. Rezervor tronconic. Baza ușor concavă, delimitată prin două caneluri fine, circulare, concentrice, are înscrisă în centru ștampila CAI, în relief. Sec. II p. Chr. Atelier provincial Dacia Superior (?). Referințe bibliografice: Bocan, Neagu 2016, p.543, no.5, fig. $2 / 5$.

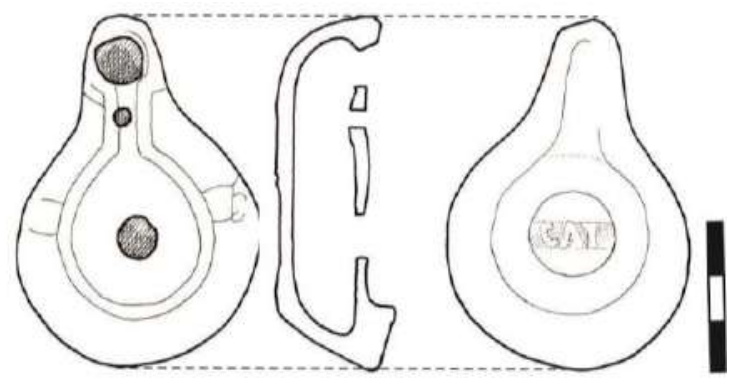

22. Opait de tip Loeschcke $X$ (întreg, lipsește un buton). Pl. IV/22; PI. IX/fig. 6. Nr. inv.: 157730. Micia 1977, castru, SII. L = 7,8 cm; $1=5,1 \mathrm{~cm} ; \mathrm{h}=$ $2,7 \mathrm{~cm}$. Pastă fină (Munsell 7.5YR 6/6, reddish yellow). Firnis parțial păstrat (Munsell 5YR 5/8, yellowish red). Ardere primară completă. Ardere secundară pe cioc, datorată utilizării. Tipar bivalv. Disc rotund, ușor concav, cu un orificiu de alimentare în centru, delimitat de bordură printr-un cordon proeminent, care se îndreaptă spre cioc, îl înconjoară și formează un canal, prevăzut cu un mic orificiu de ventilație. Bordură îngustă prevăzută cu trei butoni dispuși aproximativ simetric. Cioc alungit, rotunjit, cu un orificiu de ardere în formă de vârf de săgeată arondat. Rezervor tronconic. Baza uşor concavă, delimitată prin două caneluri fine, circulare, concentrice are înscrisă în centru ștampila CAMPILI, în relief. Sec. II p. Chr. Atelier norditalic (?). Referințe bibliografice: Bocan, Neagu 2016 , p. 543 , no. 6 , fig. $2 / 6$.

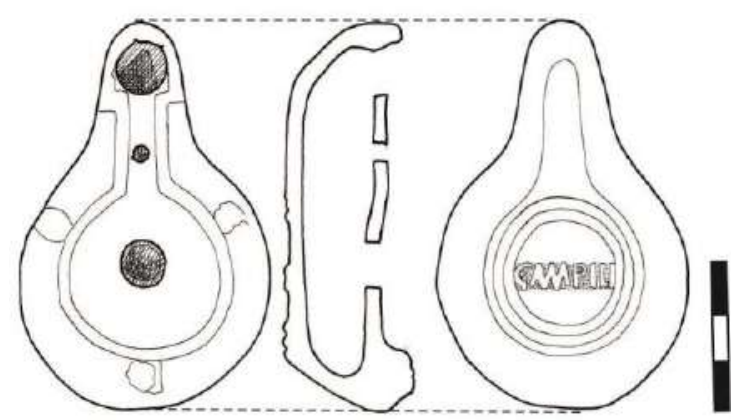


23. Opait probabil de tip Loeschcke $X$ (fragment din bază cu rezervor, cu dimensiuni de $4 \times 3 \mathrm{~cm}$ ). PI. IV/23; PI. IX/fig. 7. Nr. inv.: 131655. Micia 1977, castru, S II, carou 7. Pastă fină (Munsell 7.5YR 6/6, reddish yellow). Firnis parțial păstrat (Munsell 5YR 5/8, yellowish red). Ardere primară completă. Tipar bivalv. Descriere: Rezervor tronconic. Bază ușor concavă. Ștampila CAMPI[LI]. Sec. II p. Chr. Atelier nord-italic (?). Referințe bibliografice: Bocan, Neagu 2016, p. 543, no. 7 , fig. $2 / 7$.

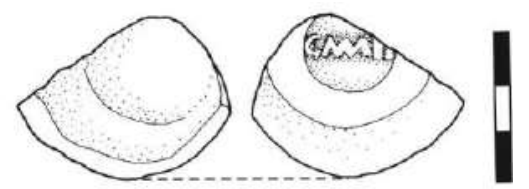

24. Opait de tip Loeschcke $X$ (fragmentar, lipsă disc și cioc). Pl. IV/24; Pl. IX/fig. 8. Nr. inv.: 131658. Micia 1977, castru, S II, carou 4, $-1,85 \mathrm{~m}$. $\mathrm{Lp}=6,3 \mathrm{~cm} ; 1=6 \mathrm{~cm} ; \mathrm{h}=3,2 \mathrm{~cm}$. Pastă fină (Munsell 5YR 7/6, reddish yellow). Firnis parțial păstrat (Munsell 2.5YR 5/8, red). Ardere primară completă. Ardere secundară pe cioc, datorată utilizării. Tipar bivalv. Disc parțial păstrat, rotund, neted, delimitat de bordură printr-un cordon. Bordură lată, prevăzută cu doi butoni dispuși aproximativ simetric. Rezervor tronconic. Baza ușor concavă, delimitată prin două caneluri fine, circulare, concentrice are înscrisă în centru ștampila FESTI, în relief. Sec. II p. Chr. Atelier nord-italic (?). Referințe bibliografice: piesa era cunoscută de Cloșca Băluță, care o amintește în lucrarea sa de doctorat - Băluță 1983, p. 67, pl. CI/11; în IDR III/6, 383, piesa este utilizată ca analogie; Bocan, Neagu 2016, p. 543, no. 8, fig. $2 / 8$.

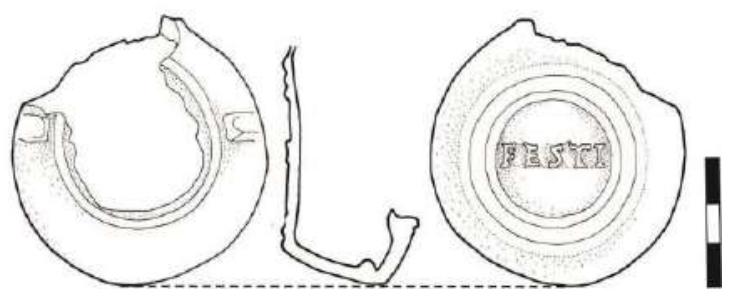

25. Opaiţ de tip Loeschcke $X$ (întregit, lipsă fragmente din rezervor și partea inferioară a ciocului). PI. IV/25; Pl. IX/fig. 9. Nr. inv.: 139887. Micia 1978, castru, S III, carou 83, $-1,60 \mathrm{~m}$. L = $8,5 \mathrm{~cm} ; 1=5,6 \mathrm{~cm} ; \mathrm{h}=3,6 \mathrm{~cm}$. Pastă fină (Munsell 5YR 7/6, reddish yellow). Firnis parțial păstrat (Munsell 5YR 5/8, yellowish red). Ardere primară incompletă. Ardere secundară pe cioc datorată utilizării. Tipar bivalv. Disc rotund, neted, ornamentat cu o mimă tragică, cu două orificii de alimentare amplasate de o parte și de alta a acesteia, delimitat de bordură printr-un cordon, care se îndreaptă spre cioc, îl înconjoară și formează un canal. Bordură lată prevăzută cu trei butoni dispuși aproximativ simetric. Cioc alungit, rotunjit, cu un orificiu de ardere în formă de vârf de săgeată arondat. Rezervor tronconic. Baza ușor concavă, delimitată prin două caneluri fine, circulare, concentrice are înscrisă în centru ștampila FORTIS, în relief. Sec. II p. Chr. Atelier nord-italic (?). Referințe bibliografice: piesa era cunoscută de Cloșca Băluță, care o amintește în lucrarea sa de doctorat - Băluță 1983, p. 72, pl. CIV/9; Bocan, Neagu 2016, p. 543-544, no. 9, fig. 3/9.

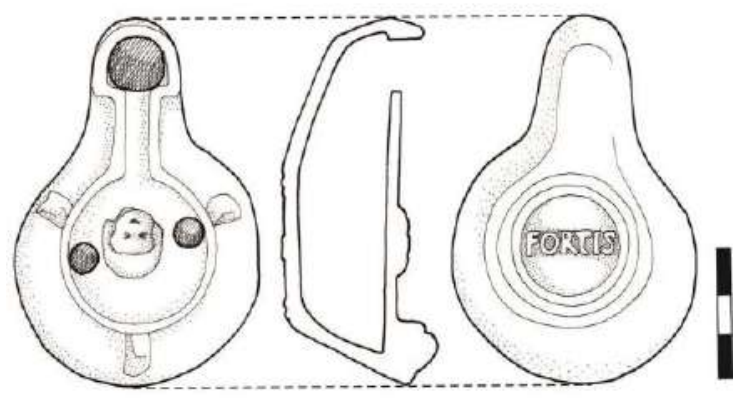

26. Opait de tip Loeschcke $X$ (fragmentar, lipsește discul). Pl. IV/26; Pl. X/fig. 10. Nr. inv.: 139874. Micia 1979, castru, S XI, carou 8, $-0,50 \mathrm{~m}$. L = 8,3 $\mathrm{cm} ; 1=5,7 \mathrm{~cm} ; \mathrm{h}=3,2 \mathrm{~cm}$. Pastă fină (Munsell 7.5YR 6/4, light brown). Firnis parțial păstrat (Munsell 5YR 5/8, yellowish red). Ardere primară completă. Ardere secundară pe cioc datorată utilizării și pe rezervor și bază datorată contacului cu o structură de combustie. Tipar bivalv. Disc rotund, neted, parțial păstrat, delimitat de bordură printr-un cordon proeminent, care se îndreaptă spre cioc, îl înconjoară și formează un canal. Bordură lată prevăzută cu trei butoni dispuși aproximativ simetric. Cioc alungit, rotunjit, cu un orificiu de ardere în formă de vârf de săgeată arondat. Rezervor tronconic. Baza dreaptă, delimitată prin două caneluri fine, circulare, concentrice are înscrisă în centru ștampila FORTIS, în relief. Sec. III p. Chr. Atelier nord-italic (?). Referințe bibliografice: piesa era cunoscută de Cloșca Băluță, care o amintește în lucrarea sa de doctorat - Băluță 1983, 72, pl. CIV/8; Bocan, Neagu 2016, p. 544, no. 10 , fig. $3 / 10$.

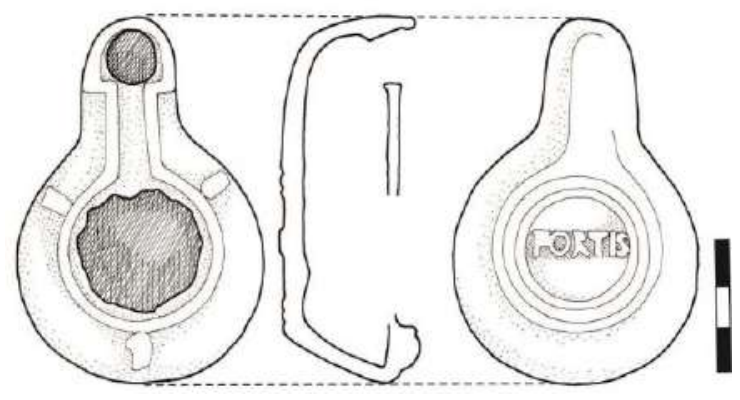


27. Opaiț de tip Loeschcke $X$ (fragmentar, lipsește o parte din capac). Pl. IV/27; Pl. X/fig. 11. Nr. inv.: 131659. Micia 1978, castru, S III, carou $75,-1,15$ m. L = $8 \mathrm{~cm} ; 1=5,4 \mathrm{~cm} ; \mathrm{hp}=2,6 \mathrm{~cm}$. Pastă fină (Munsell 5YR 7/6, reddish yellow). Firnis parțial păstrat (Munsell 5YR 5/8, yellowish red). Ardere primară completă. Puternic ars secundar pe cioc, rezervor și bază. Tipar bivalv. Disc rotund, neted (?) delimitat de bordură printr-un cordon proeminent, care se îndreaptă spre cioc, îl înconjoară şi formează un canal, prevăzut cu un mic orificiu de ventilație. Bordura îngustă, păstrează un buton. Cioc alungit, rotunjit, cu un orificiu de ardere în formă de vârf de săgeată arondat. Rezervor tronconic. Baza dreaptă, delimitată prin două caneluri fine, circulare, concentrice are înscrisă în centru ștampila FORTIS, în relief. Sec. III p. Chr. Atelier provincial Dacia Superior (?). Referințe bibliografice: piesa era cunoscută de Cloșca Băluță, care o amintește în lucrarea sa de doctorat - Băluță 1983, p. 72, pl. CIV/7; Bocan, Neagu 2016, p. 544, no. 13, fig. 3/13.

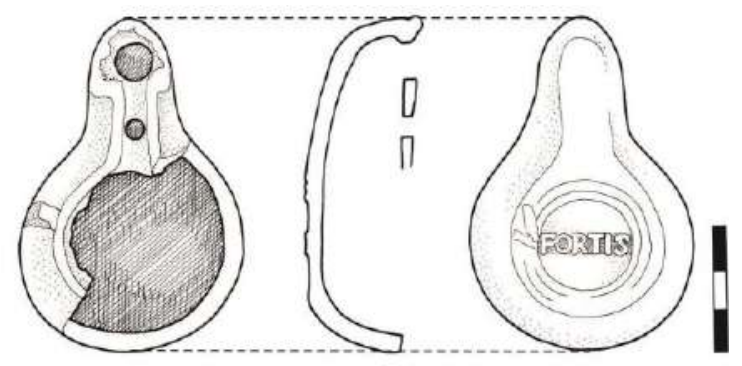

28. Opaiț de tip Loeschcke $X$ (fragmentar, lipsește ciocul). Pl. IV/28; Pl. X/fig. 12. Nr. inv.: 338492. Micia 1983, castru, S XXV, carou 24, $-0,80$ m. Lp $=5,8 \mathrm{~cm} ; 1=5,8 \mathrm{~cm} ; \mathrm{h}=3,2 \mathrm{~cm}$. Pastă fină (Munsell 7.5YR 7/6, reddish yellow). Firnis parțial păstrat (Munsell 10R 4/6, red). Ardere primară completă. Ardere secudare pe capac și bază. Tipar bivalv. Disc rotund, neted, cu un orificiu de alimentare în centru, delimitat de bordură printr-un cordon proeminent. Bordură lată, prevăzută cu trei butoni. Rezervor tronconic. Baza ușor concavă, delimitată prin două caneluri fine, circulare, concentrice are înscrisă în centru ștampila FORTIS, în relief. Sec. II p. Chr. Atelier nord-italic (?). Referințe bibliografice: Bocan, Neagu 2016, p. 544, no. 11 , fig. $3 / 11$.

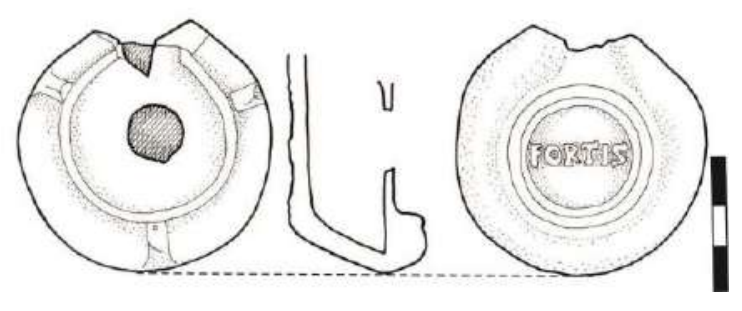

29. Opaiț de tip Loeschcke $X$ (fragmentar, lipsesc fragmente din disc, bordură și ciocul). PI. IV/29; Pl. X/fig. 13. Nr. inv.: 139891. Micia 1979, castru, $\mathrm{S} X$, carou $62,-0,92 \mathrm{~m} . \mathrm{Lp}=5,3 \mathrm{~cm} ; 1=5,2 \mathrm{~cm} ; \mathrm{h}$ $=2,5 \mathrm{~cm}$. Pastă fină (Munsell 10YR 6/4, light yellowish brown). Firnis parțial păstrat (Munsell 5YR 4/6, yellowish red). Ardere primară completă. Puternic ars secundar pe toată suprafața. Tipar bivalv. Disc rotund, neted, delimitat de bordură printr-un cordon. Bordura îngustă păstrează un buton. Rezervor tronconic. Baza ușor concavă, delimitată prin două caneluri fine, circulare, concentrice, are înscrisă în centru ștampila FORTIS, în relief. Sec. II p. Chr. Atelier provincial Dacia Superior (?). Referințe bibliografice: Bocan, Neagu 2016, p. 544, no. 14, fig. 3/14.

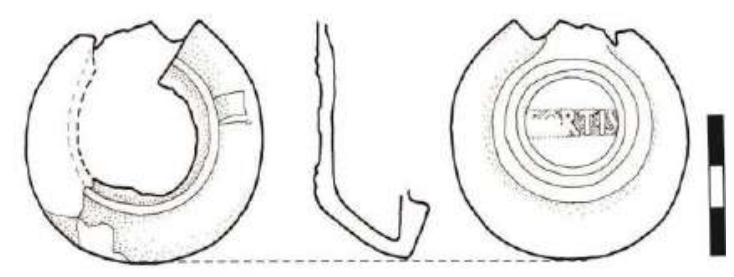

30. Opait de tip Loeschcke $\mathbf{X}$ (fragment din rezervor cu bază). Pl. V/30; Pl. X/fig. 14. Nr. inv.: 338493. Micia 1979, castru, S X, carou 81. Lp = 5,1 $\mathrm{cm} ; \mathrm{lp}=2,2 \mathrm{~cm} ; \mathrm{hp}=2 \mathrm{~cm}$. Pastă fină (Munsell 5 YR $7 / 6$ reddish yellow). Firnis parțial păstrat (Munsell 2.5YR 5/8, red). Ardere primară completă. Tipar bivalv. Rezervor tronconic. Baza dreaptă, delimitată prin două caneluri fine, circulare, concentrice, are înscrisă în centru ștampila [FOR]TIS. Sec. II p. Chr. Atelier norditalic (?). Referinte bibliografice: Bocan, Neagu 2016 , p. 544 , no. 12 , fig. $3 / 12$.

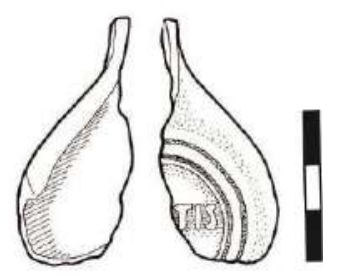

31. Opaiţ de tip Loeschcke $X$ (fragment din cioc, capac, rezervor şi bază). Pl. V/31; Pl. X/fig. 15. Nr. inv.: 338537. Micia 1979, castru, S III, carou 41, 0,85 m. Lp $=7 \mathrm{~cm} ; \mathrm{lp}=4,7 \mathrm{~cm} ; \mathrm{h}=2,9 \mathrm{~cm}$. Pastă fină (Munsell 5YR 6/8 reddish yellow). Firnis parțial păstrat (Munsell 5YR 5/8, yellowish red). Ardere primară completă. Tipar bivalv. Disc rotund, ușor concav, delimitat de bordură printr-un cordon proeminent care se îndreaptă spre cioc, îl înconjoară și formează un canal prevăzut cu un mic orificiu de ventilație. Bordură lată, parțial păstrată, cu un buton, decorată cu o rețea de incizii. Cioc rotunjit, alungit, cu un orificiu de ardere în formă de vârf de săgeată arondat. Rezervor tronconic. Baza delimitată prin două profilaturi circulare, 
concentrice are înscrisă în centru ștampila IA[NVARI] (?). Sec. II p. Chr. Atelier provincial Dacia Superior (?). Referințe bibliografice: Bocan, Neagu 2016, p. 544, no. 15, fig. 3/15.

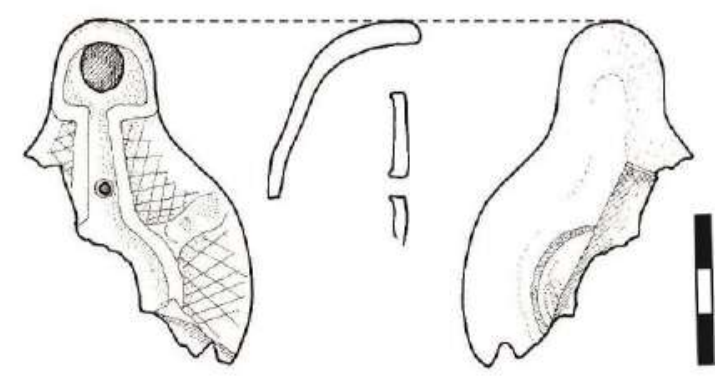

32. Opait de tip Loeschcke $X$ (fragmentar, lipsește o parte din cioc). Pl. V/32; Pl. X/fig. 16. Nr. inv.: 131706. Micia 1977, castru, S II, carou $88,-0,95$ m. Lp = 6,2 cm; $1=5,4 \mathrm{~cm} ; \mathrm{h}=3 \mathrm{~cm}$. Pastă fină (Munsell 10YR 7/4 very pale brown). Firnis parțial păstrat (Munsell 2.5YR 5/8, red). Ardere primară completă. Ardere secundară pe bază. Tipar bivalv. Disc rotund, neted, cu un orificiu de alimentare în centru, delimitat de bordură printr-un cordon proeminent, care se îndreaptă spre cioc, probabil, îl înconjoară și formează un canal prevăzut cu un mic orificiu de ventilație. Bordură lată, prevăzută cu trei butoni dispuși aproximativ simetric. Rezervor tronconic. Baza dreaptă, delimitată prin două caneluri fine, circulare, concentrice, are înscrisă în centru ștampila MIA, în relief. Sec. II p. Chr. Origine: atelier nord-italic (?). Referințe bibliografice: piesa era cunoscută de Cloșca Băluță, care o amintește în lucrarea sa de doctorat - Băluță 1983, p. 87, pl. CX/23; IDR III/6, 387, piesa este utilizată ca analogie; Bocan, Neagu 2016, p. 544, no. 16 , fig. $3 / 16$.

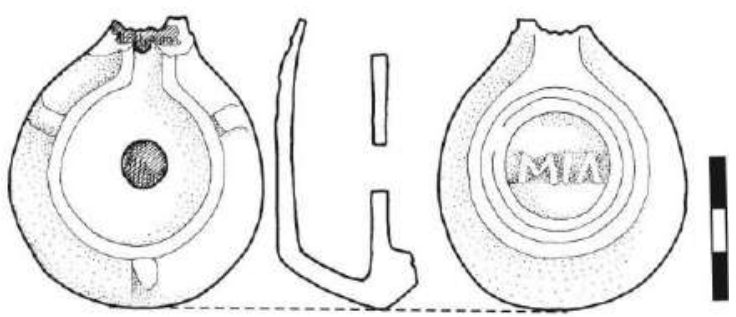

33. Opait bilychnis, de tip Loeschcke $X$ (fragment din partea inferioară a unuia dintre orificiile de ardere cu rezervor și bază). Pl. V/33; Pl. X/fig. 17. Nr. inv.: 338494. Micia 1982, castru, S XXII, carou 2, $-1,52 \mathrm{~m} . \mathrm{Lp}=5,9 \mathrm{~cm} ; \mathrm{lp}=3,5 \mathrm{~cm} ; \mathrm{hp}=1,4 \mathrm{~cm}$. Pastă fină (Munsell 10YR 6/4 light yellowish brown). Firnis parțial păstrat (Munsell 10R 5/8, red). Ardere primară completă. Tipar bivalv. Cioc, probabil alungit, prevăzut cu două orificii de ardere din care se păstrează unul. Rezervor tronconic. Baza concavă, delimitată prin două caneluri fine, circulare, concentrice are înscrisă în centru ștampila OPTA[TI]. Sec. II p. Chr. Atelier provincial Dacia Superior (?). Referințe bibliografice: Bocan, Neagu 2016 , p. 544 , no. 17 , fig. $4 / 17$.

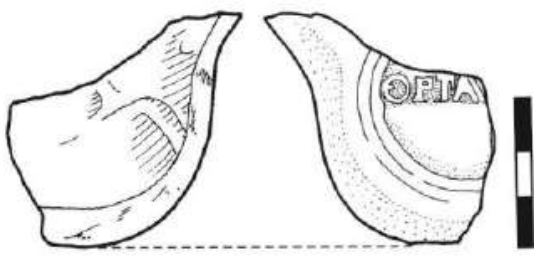

34. Opait de tip Loeschcke $X$ (fragmentar, lipsește mare parte din disc, o parte din bordură, canal, partea superioară a ciocului, fragmente din rezervor și bază). Pl. V/34; Pl. X/fig. 18. Nr. inv.: 124108. Micia 1976, castru, S I, carou 29, $-1,40$ m. Lp = 10 $\mathrm{cm} ; \mathrm{lp}=6,2 \mathrm{~cm} ; \mathrm{h}=3,8 \mathrm{~cm}$. Pastă fină (Munsell 10YR 6/6, brownish yellow). Firnis parțial păstrat (Munsell 7.5YR 4/4, brown). Ardere primară completă. Tipar bivalv. Pe bordură două incizii în forma literei $\mathrm{X}$, realizate probabil recent, după descoperirea piesei. Disc parțial păstrat, rotund, neted (?) delimitat de bordură printr-un cordon, care se îndreaptă spre cioc și formează un canal parțial păstrat. Bordura păstrează doi butoni bifizi, dispuși între două linii adâncite. Cioc alungit, rotunjit, cu un orificiu de ardere. Rezervor tronconic. Baza ușor concavă, delimitată prin două caneluri fine, circulare, concentrice are înscrisă în centru ștampila STROBILI, în relief. Sec. II p. Chr. Atelier norditalic (?). Referințe bibliografice: piesa era cunoscută de Cloșca Băluță, care o amintește în lucrarea sa de doctorat - Băluță 1983, p. 100, pl. CXII/24; IDR III/6, 410, piesa este utilizată ca analogie; Bocan, Neagu 2016, p. 544, no. 18, fig. $4 / 18$.

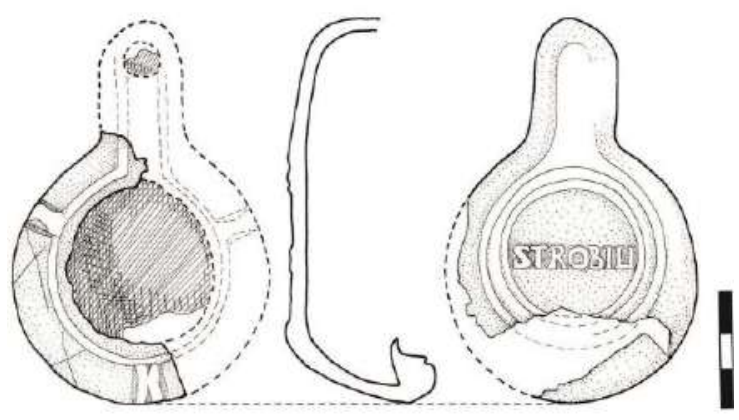

35. Opaiț de tip Loeschcke X (întreg). PI. V/35. Nr. inv.: 131660. Micia 1977, castru, S II, carou 48, $-0,60 \mathrm{~m} . \mathrm{L}=7,2 \mathrm{~cm} ; 1=5 \mathrm{~cm} ; \mathrm{h}=2,5 \mathrm{~cm}$. Pastă fină (Munsell 7,5YR 7/6, reddish yellow). Firnis parțial păstrat (Munsell 5YR 6/8, reddish yellow). Ardere primară incompletă. Ardere secundară pe cioc datorată utilizării. Tipar bivalv. Disc rotund, uşor concav, cu un orificiu de alimentare în centru, delimitat de bordură printr-un cordon, care se îndreaptă spre cioc, îl înconjoară și formează un 
canal prevăzut cu un mic orificiu de ventilație. Bordură îngustă, prevăzută cu trei butoni dispuși aproximativ simetric. Cioc alungit, rotunjit, cu un orificiu de ardere. Rezervor tronconic. Bază ușor concavă. Ștampilă ilizibilă. Sec. II p. Chr. Atelier local Micia (?). Referințe bibliografice: Bocan, Neagu 2016, p. 544, no. 19, fig. 4/19.

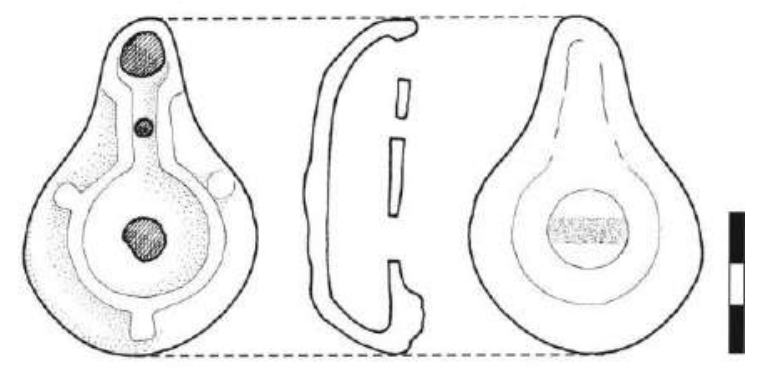

\section{Lămpi anepigrafice de tip Loeschcke X}

36. Opait de tip Loeschcke $X$ (întreg). Pl. V/36. Nr. inv.: 338495. Micia 1967, castru, zidul castrului, canal. $\mathrm{L}=7,9 \mathrm{~cm} ; 1=5,2 \mathrm{~cm} ; \mathrm{h}=3,1 \mathrm{~cm}$. Pastă fină (Munsell 7.5YR 6/6, reddish yellow). Ardere primară incompletă. Ardere secundară pe cioc datorată utilizării. Ardere secundară pe bordură, rezervor și bază datorată contactului cu o sursă de combustie. Tipar bivalv. Disc rotund, neted, cu un orificiu de alimentare în centru, delimitat de bordură printr-un cordon proeminent, care se îndreaptă spre cioc, îl înconjoară și formează un canal, prevăzut cu un mic orificiu de ventilație. Bordura îngustă, prevăzută cu trei butoni bifizi, dispuși aproximativ simetric. Butonii pornesc din cordon. Cioc alungit, rotunjit, cu un orificiu de ardere. Rezervor tronconic. Bază ușor concavă. Sec. II-III p. Chr. Atelier local Micia (?). Inedit.

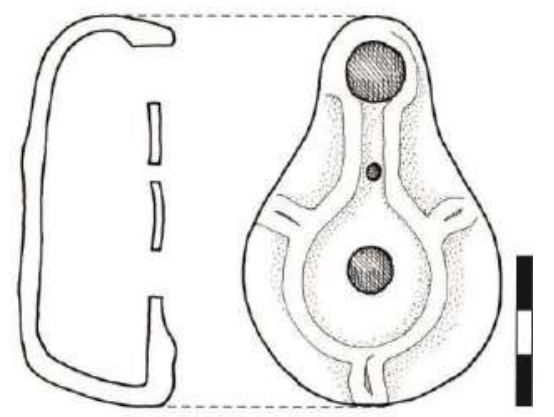

37. Opaiț de tip Loeschcke X (întreg). PI. V/37. Nr. inv.: 338496. Micia 1985, castru, S XXVII, carou $6,-0,95 \mathrm{~m} . \mathrm{L}=6,8 \mathrm{~cm} ; 1=4,5 \mathrm{~cm} ; \mathrm{h}=2,7$ cm. Pastă fină (Munsell 7.5YR 6/6, reddish yellow). Firnis parțial păstrat (Munsell 5YR 6/8, reddish yellow). Ardere primară completă. Ardere secundară pe cioc datorată utilizării. Tipar bivalv. Disc rotund, neted, cu un orificiu de alimentare, delimitat de bordură printr-un cordon, care se îndreaptă spre cioc, îl înconjoară şi formează un canal. Bordura îngustă, prevăzută cu trei butoni dispuși aproximativ simetric este decorată cu o rețea de incizii. Butonii pornesc din cordon. Cioc alungit, rotunjit, cu un orificiu de ardere. Rezervor tronconic. Bază concavă. Sec. II-III p. Chr. Atelier local Micia (?). Inedit.

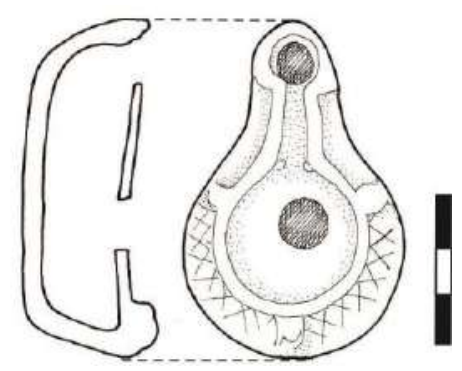

38. Opaiț de tip Loeschcke $\mathbf{X}$ (fragmentar, lipsesc fragmente din disc, rezervor și bază). Pl. V/38. Nr. inv.: 139886. Micia 1979, castru, S XV, carou 2, $1,00 \mathrm{~m} . \mathrm{L}=8,2 \mathrm{~cm} ; 1=5,7 \mathrm{~cm} ; \mathrm{h}=2,5 \mathrm{~cm}$. Pastă fină (Munsell 2.5YR 6/4, weak red). Firnis parțial păstrat (Munsell 2.5YR 5/8, red). Ardere primară completă. Ardere secundară pe cioc datorată utilizării intense. Tipar bivalv. Descriere: Disc parțial păstrat, rotund, neted (?) delimitat de bordură printr-un cordon, care se îndreaptă spre cioc, îl înconjoară și formează un canal. Bordură îngustă, prevăzută cu doi butoni dispuși aproximativ simetric. Cioc alungit, rotunjit, cu un orificiu de ardere în formă de vârf de săgeată arondat. Rezervor tronconic. Bază parțial păstrată, uşor concavă, delimitată prin două caneluri fine, circulare, concentrice. Sec. III p. Chr. Atelier provincial Dacia Superior (?). Inedit.

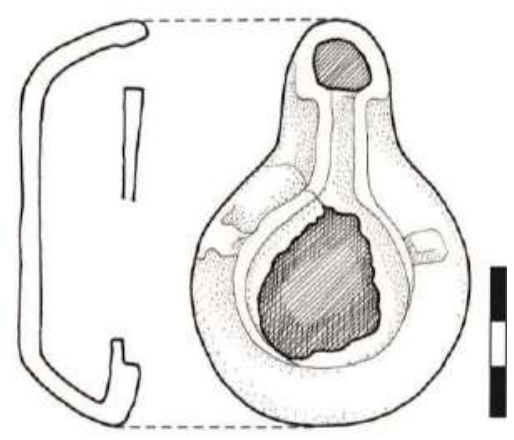

39. Opaiț de tip Loeschcke $X$ (fragmentar, lipsesc fragmente din disc, bordură, rezervor și bază). PI. V/39. Nr. inv.: 338497. Micia 1967, castru, zidul castrului, canal. $\mathrm{L}=7,8 \mathrm{~cm} ; 1=5,2 \mathrm{~cm} ; \mathrm{h}=2,8 \mathrm{~cm}$. Pastă fină (Munsell 7.5YR 6/6, reddish yellow). Ardere primară completă. Ardere secundară pe cioc datorată utilizării. Tipar bivalv. Disc parţial păstrat, rotund, delimitat de bordură printr-un cordon care se îndreaptă spre cioc, îl înconjoară și formează un canal. Bordură îngustă, prevăzută cu trei butoni bifizi dispuși aproximativ simetric. Butonii pornesc din cordon. Cioc alungit, rotunjit, cu un orificiu de 
ardere. Rezervor tronconic. Bază concavă. Sec. IIIII p. Chr. Atelier local Micia (?). Inedit.

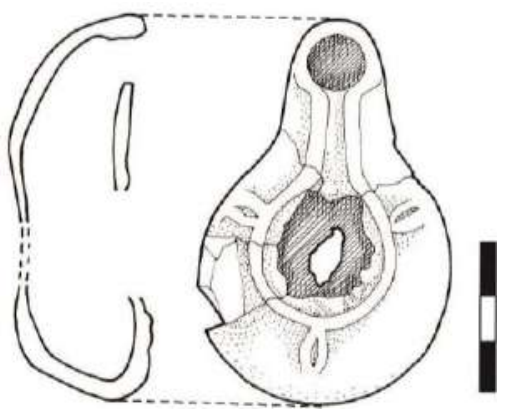

40. Opait de tip Loeschcke $X$ (fragmentar, lipsesc fragmente din rezervor și ciocul). Pl. V/40. Nr. inv.: 338498. Micia 1967, castru, zidul castrului, canal. $\mathrm{Lp}=6,5 \mathrm{~cm} ; 1=6,6 \mathrm{~cm} ; \mathrm{h}=3,2 \mathrm{~cm}$. Pastă fină de culoare roșie deschisă (Munsell 7.5YR 7/6, reddish yellow). Firnis de culoare roșie închisă (Munsell 2.5YR 4/8, dark red). Ardere primară completă. Ardere secundară pe cioc datorată utilizării. Tipar bivalv. Disc rotund, neted, cu un orificiu de alimentare în centru, delimitat de bordură printr-un cordon. Bordură prevăzută cu trei butoni dispuși aproximativ simetric, decorată cu incizii radiale. Rezervor tronconic. Bază concavă. Sec. II-III p. Chr. Atelier provincial Dacia Superior (?). Inedit.

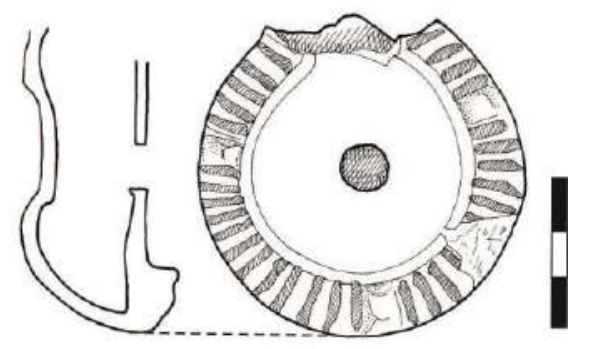

41. Opait de tip Loeschcke $X$ (fragmentar, se păstrează capacul și ciocul). Pl. V/41. Nr. inv.: 139876. Micia 1979, castru, S X, carou 62, $-1,08$ m. $\mathrm{L}=10,6 \mathrm{~cm} ; 1=7 \mathrm{~cm}$; hestimativă $=4,8 \mathrm{~cm}$. Pastă fină (Munsell 2.5YR 6/8, red). Firnis parțial păstrat (Munsell 10YR 4/6, red). Ardere primară completă. Ardere secundară pe cioc datorată utilizării. Tipar bivalv. Disc rotund, neted, cu un orificiu de alimentare în centru, delimitat de bordură printr-un cordon care se îndreaptă spre cioc, îl înconjoară și formează un canal prevăzut cu un mic orificiu de ventilație. Bordură lată, prevăzută cu trei butoni bifizi, dispuși aproximativ simetric. Cioc alungit, rotunjit, cu un orificiu de ardere în formă de vârf de săgeată arondat. Sec. IIIII p. Chr. Atelier nord-italic (?). Inedit.

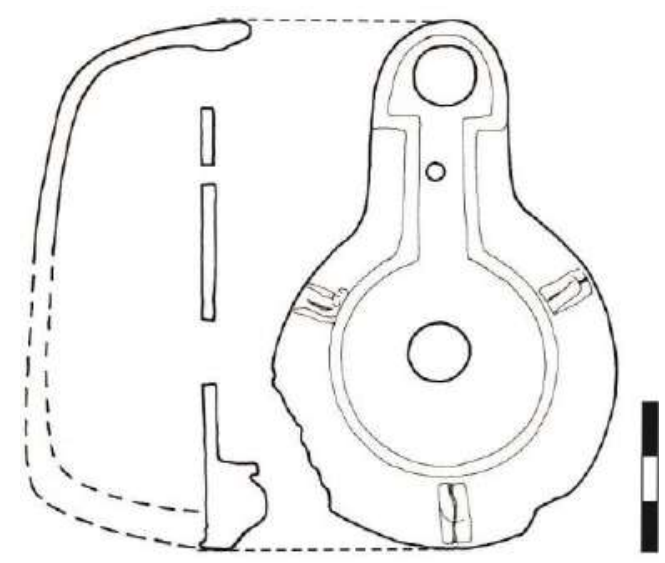

42. Opait de tip Loeschcke $X$ (întregit). Pl. V/42. Nr. inv.: 139878. Micia 1978, castru, S III, carou $83,-1,60 \mathrm{~m}$. Lestimativă $=6,7 \mathrm{~cm}$; lestimativă $=$ $4,4 \mathrm{~cm} ; \mathrm{h}=2,6 \mathrm{~cm}$. Pastă fină (Munsell 5YR 6/6, reddish yellow). Firnis parțial păstrat (Munsell 5YR 4/6, yellowish red). Ardere primară completă. Ardere secundară pe cioc datorată utilizării. Tipar bivalv. Disc parțial păstrat, oval, neted, cu un orificiu de alimentare în centru, delimitat de bordură printr-un cordon proeminent care se îndreaptă spre cioc, îl înconjoară și formează un canal, prevăzut cu un mic orificiu de ventilație (?). Bordură îngustă. Cioc alungit, rotunjit, cu un orificiu de ardere. Rezervor tronconic. Bază dreaptă. Sec. II p. Chr. Atelier local Micia (?). Inedit.

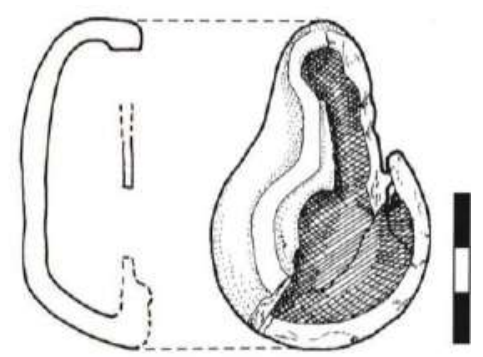

43. Opait de tip Loeschcke $X$ (fragmentar, se păstrează fragmente din capac, cioc, rezervor și bază). Pl. V/43. Nr. inv.: 124103. Micia 1976, castru, S I. Lp = $6 \mathrm{~cm}$; lestimativă $=5,3 \mathrm{~cm} ; \mathrm{h}=2,3$ cm. Pastă fină (Munsell 10YR 6/6, brownish yellow). Ardere primară incompletă. Tipar bivalv. Disc parţial păstrat, rotund, neted, cu un orificiu de alimentare în centru, delimitat de bordură printr-un cordon care se îndreaptă spre cioc, îl înconjoară și formează un canal, prevăzut cu un mic orificiu de ventilație. Bordura îngustă păstrează doi butoni. Cioc alungit. Rezervor tronconic. Bază ușor 
concavă. Sec. II-III p. Chr. Atelier provincial Dacia Superior (?). Inedit.

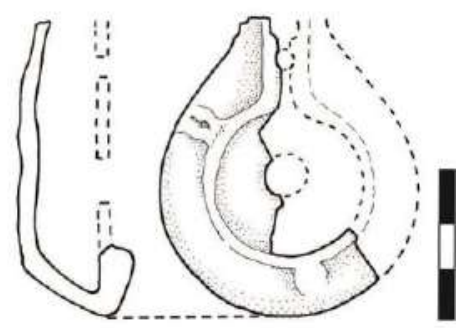

44. Opaiţ de tip Loeschcke $X$ (fragmentar, se păstrează fragmente din capac, rezervor și bază). PI. VI/44. Nr. inv.: 139888. Micia 1979, castru, S X, caseta 2, carou $53,-1,00 \mathrm{~m} . \mathrm{Lp}=5,5 \mathrm{~cm} ; \mathrm{lp}=4,7$ $\mathrm{cm}$; hestimativă $=2,5 \mathrm{~cm}$. Pastă fină (Munsell 7.5YR 7/6, reddish yellow). Firnis parțial păstrat (Munsell 2.5YR 5/8, red). Ardere primară incompletă. Tipar bivalv. Disc parțial păstrat, rotund, neted, cu un orificiu de alimentare aproximativ în centru, delimitat de bordură printrun cordon care se îndreaptă spre cioc şi formează un canal. Bordura îngustă păstrează un buton. Rezervor tronconic. Bază uşor concavă. Sec. II p. Chr. Atelier provincial Dacia Superior (?). Inedit.

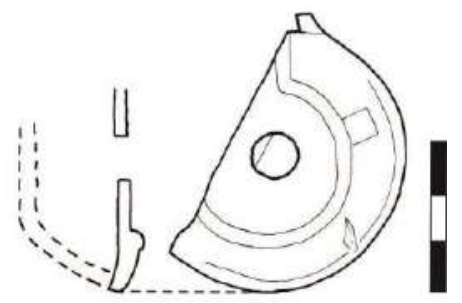

45. Opaiț de tip Loeschcke $X$ (fragment din capac, cioc, rezervor şi bază). PI. VI/45. Nr. inv.: 338499. Micia 1981, castru, S XIX, carou 2, lățire, $-0,65$ m. $\mathrm{Lp}=8,2 \mathrm{~cm} ; \mathrm{lp}=2,2 \mathrm{~cm} ; \mathrm{h}=3,3 \mathrm{~cm}$. Pastă fină (Munsell 5YR 6/8, reddish yellow). Ardere primară incompletă. Ardere secundară pe cioc datorată utilizării. Tipar bivalv. Disc parțial păstrat, rotund, ușor concav, delimitat de bordură printr-un cordon care se îndreaptă spre cioc, îl înconjoară și formează un canal. Bordura îngustă păstrează un buton. Cioc alungit, rotunjit, cu un orificiu de ardere. Rezervor tronconic. Bază ușor concavă. Sec. II p. Chr. Atelier local Micia (?). Inedit.

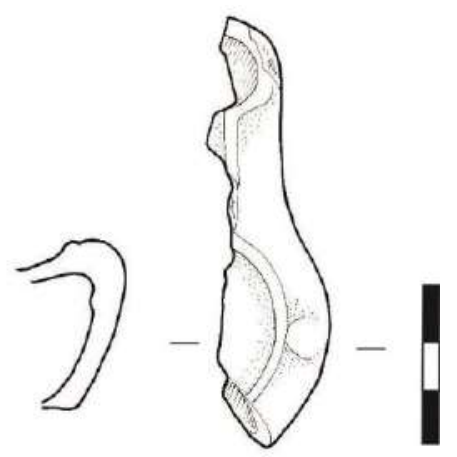

46. Opait de tip Loeschcke X (fragmentar, se păstrează un fragment din capac și un fragment din rezervor cu bază). Pl. VI/46. Nr. inv.: 139877. Micia 1976, castru, S I, carou 29, $-1,46$ m. Lp = 5,7 $\mathrm{cm} ; 1 \mathrm{p}=2 \mathrm{~cm} ; \mathrm{h}=2,9 \mathrm{~cm}$. Pastă fină (Munsell 5YR $5 / 6$, yellowish red). Ardere primară completă. Ardere secundară pe bordură. Tipar bivalv. Disc parțial păstrat, rotund, neted, delimitat de bordură printr-un cordon. Bordura îngustă păstrează un buton. Cioc alungit (?). Rezervor tronconic. Bază ușor concavă. Sec. II p. Chr. Atelier local Micia (?). Inedit.

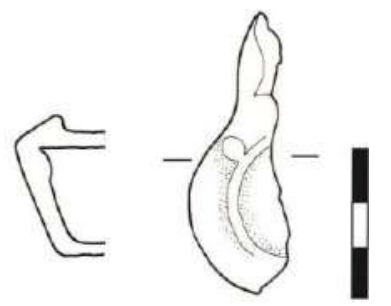

47. Opaiț de tip Loeschcke $X$ (fragmentar, se păstrează două fragmente din capac, un fragment din capac cu rezervor și un fragment din bază cu rezervor). Pl. VI/47. Nr. inv.: 162503-162506. Micia 1976, castru, S I, carou 76, $-1,00$ m. Lp = 6,2 $\mathrm{cm} ; \mathrm{lp}=5,4 \mathrm{~cm} ; \mathrm{h}=2,8 \mathrm{~cm}$. Pastă fină (Munsell 7.5YR 7/8, reddish yellow). Firnis parțial păstrat (Munsell 2.5YR 5/8, red). Ardere primară completă. Tipar bivalv. Disc parțial păstrat, rotund, neted, delimitat de bordură printr-un cordon care se îndreaptă spre cioc și formează un canal. Bordura îngustă păstrează doi butoni. Rezervor tronconic. Bază ușor concavă. Sec. II p. Chr. Atelier local Micia (?). Inedit.

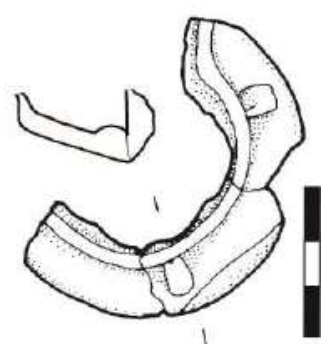

48. Opait de tip Loeschcke $X$ (fragment din capac). Pl. VI/48. Nr. inv.: 338500. Micia 1967, castru, zidul castrului, canal. Lp $=12,5 \mathrm{~cm} ; 1=9$ $\mathrm{cm} ; \mathrm{hp}=3,7 \mathrm{~cm}$. Pastă fină (Munsell 5YR 6/8, reddish yellow). Firnis parțial păstrat (Munsell 2.5YR 4/8, dark red). Ardere primară completă. Ardere secundară pe cioc datorată utilizării. Tipar bivalv. Urme de mortar pe toată suprafața. Disc parțial păstrat, rotund, neted, delimitat de bordură printr-un cordon proeminent care se îndreaptă spre cioc, îl înconjoară și formează un canal, prevăzut cu un mic orificiu de ventilație. Bordură lată. Cioc 
alungit, cu un orificiu de ardere. Este prevăzut cu o toartă inelară, lată, cu două caneluri, atașată pe bordură. Sec. II-III p. Chr. Atelier provincial Dacia Superior (?). Inedit.

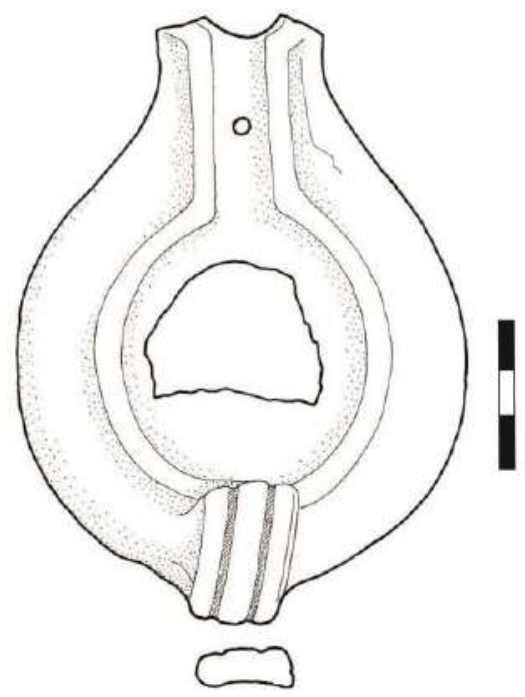

49. Opaiţ de tip Loeschcke $X$ (fragmentar, se păstrează capacul cu o parte din rezervor). Pl. VI/49. Nr. inv.: 176144. Micia 1981, castru, S XVIII, carou $13,-0,50 \mathrm{~m} . \mathrm{L}=9,4 \mathrm{~cm} ; 1=6,4 \mathrm{~cm}$; hp $=1,4$ cm. Pastă fină (Munsell 5YR 6/8, reddish yellow). Ardere primară completă. Ardere secundară pe cioc datorată utilizării. Tipar bivalv. Disc parțial păstrat, rotund, neted, cu un orificiu de alimentare în centru (?) delimitat de bordură printrun cordon care se îndreaptă spre cioc, îl înconjoară şi formează un canal, prevăzut cu un mic orificiu de ventilație. Bordură lată, prevăzută cu trei butoni bifizi dispuși aproximativ simetric. Butonii pornesc din cordon. Cioc alungit, cu un orificiu de ardere. Sec. II-III p. Chr. Atelier local Micia (?). Inedit.

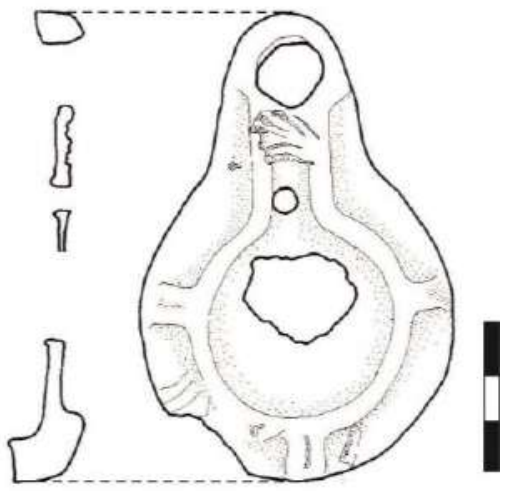

50. Opait de tip Loeschcke $\mathbf{X}$ (fragment din capac). Pl. VI/50. Nr. inv.: 338501. Micia 1983, castru, S XXV, carou $25,-0,50 \mathrm{~m}$. Lp $=8,7 \mathrm{~cm}$; lp $=4,5 \mathrm{~cm} ; \mathrm{hp}=1 \mathrm{~cm}$. Pastă fină (Munsell 5YR 6/6, reddish yellow). Firnis parțial păstrat (Munsell 5YR 4/6, yellowish red). Ardere primară completă. Ardere secundară pe cioc datorată utilizării. Tipar bivalv. Disc parțial păstrat, rotund, neted, delimitat de bordură printr-un cordon care se îndreaptă spre cioc, îl înconjoară și formează un canal. Bordura lată păstrează un buton. Cioc alungit, cu un orificiu de ardere. Particularitate: canal incomplet perforat în vederea realizării unui orificiu de ventilație. Sec. II-III p. Chr. Atelier nord-italic (?). Inedit.

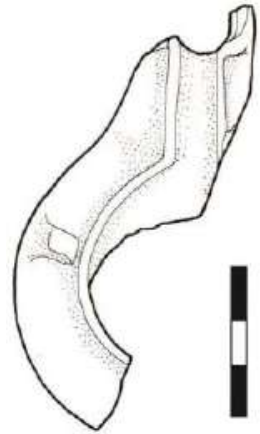

51. Opait de tip Loeschcke $X$ (fragmentar, se păstrează capacul). Pl. VI/51. Nr. inv.: 139875. Micia 1979, castru, S X, carou 63, $-1,70 \mathrm{~m}$. Lp = $7,6 \mathrm{~cm} ; 1=5,5 \mathrm{~cm} ; \mathrm{hp}=1,5 \mathrm{~cm}$. Pastă fină (Munsell 5YR 6/6, reddish yellow). Firnis parțial păstrat (Munsell 10R 4/8, red). Ardere primară completă. Ardere secundară pe cioc datorată utilizării. Tipar bivalv. Disc rotund, neted, cu un orificiu de alimentare în centru, delimitat de bordură printr-un cordon care se îndreaptă spre cioc, îl înconjoară și formează un canal, prevăzut cu un mic orificiu de ventilație. Bordură lată, prevăzută cu trei butoni dispuși aproximativ simetric. Cioc alungit, cu un orificiu de ardere în formă de vârf de săgeată arondat. Sec. II p. Chr. Atelier provincial Dacia Superior (?). Inedit.

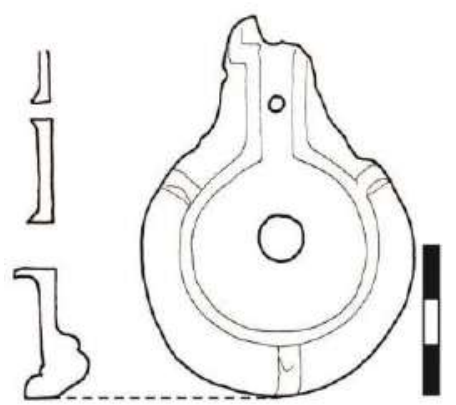

52. Opait de tip Loeschcke $X$ (fragment din capac). Pl. VI/52. Nr. inv.: 176156. Micia 1981, castru, S XVII, carou 13, $-1,20 \mathrm{~m}$. Lp = 7,5 cm; $1=$ $6 \mathrm{~cm} ; \mathrm{hp}=1,2 \mathrm{~cm}$. Pastă fină (Munsell 5YR 6/6, reddish yellow). Ardere primară completă. Tipar bivalv. Disc rotund, ușor concav, delimitat de bordură printr-un cordon care se îndreaptă spre cioc, îl înconjoară și formează un canal, prevăzut cu un mic orificiu de ventilație. Bordură îngustă, prevăzută cu trei butoni dispuși aproximativ simetric, decorată, probabil, cu o rețea de incizii (?). 
Cioc alungit, cu un orificiu de ardere. Sec. II p. Chr. Atelier provincial Dacia Superior (?). Inedit.

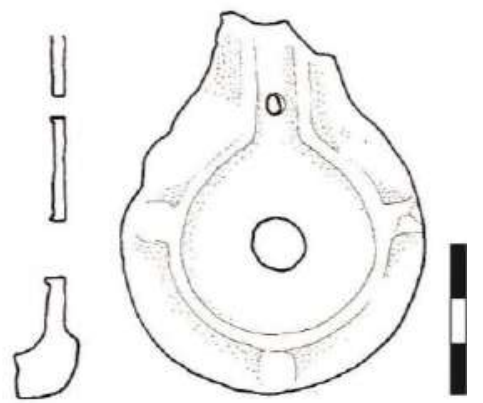

53. Opait de tip Loeschcke $X$ (fragment din capac). Pl. VI/53. Nr. inv.: 139880. Micia 1979, castru, S X, carou 63, $-1,70 \mathrm{~m}$. Lp $=7 \mathrm{~cm} ; 1=5,3$ $\mathrm{cm} ; \mathrm{hp}=1,4 \mathrm{~cm}$. Pastă fină (Munsell 5YR 6/6, reddish yellow). Firnis parțial păstrat (Munsell 2.5 YR 5/8 red). Ardere primară completă. Tipar bivalv. Disc rotund, neted, cu un orificiu de alimentare în centru, delimitat de bordură printr-un cordon care se îndreaptă spre cioc, îl înconjoară și formează un canal, prevăzut cu un mic orificiu de ventilație. Bordură îngustă, prevăzută cu doi butoni dispuși aproximativ simetric. Cioc alungit, cu un orificiu de ardere. Sec. II-III p. Chr. Atelier provincial Dacia Superior (?). Inedit.

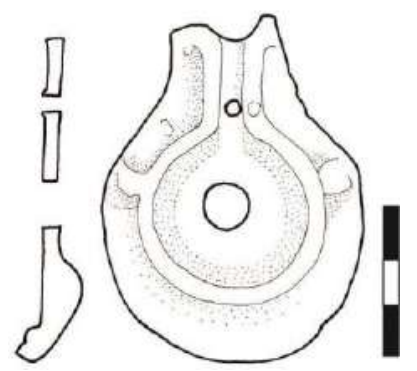

54. Opait de tip Loeschcke $\mathbf{X}$ (fragment din capac). Pl. VI/54. Nr. inv.: 176145. Micia 1981, castru, S XVIII, carou 10, $-1,00 \mathrm{~m}$. Lp $=7 \mathrm{~cm} ; 1=$ $5,5 \mathrm{~cm} ; \mathrm{hp}=1 \mathrm{~cm}$. Pastă fină (Munsell 7.5YR 6/6, reddish yellow). Firnis parțial păstrat (Munsell 2.5 YR 4/8, dark red). Ardere primară completă. Tipar bivalv. Disc rotund, neted, cu un orificiu de alimentare în centru, delimitat de bordură printr-un cordon proeminent, care se îndreaptă spre cioc, îl înconjoară și formează un canal, prevăzut cu un mic orificiu de ventilație. Bordură prevăzută cu doi butoni bifizi, dispuși aproximativ simetric, decorată atât cu incizii radiale, cât și cu o rețea de incizii. Butonii pornesc din cordon. Cioc alungit, cu un orificiu de ardere. Sec. II p. Chr. Atelier provincial Dacia Superior (?). Inedit.

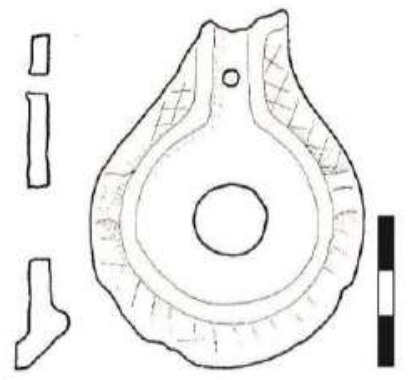

55. Opaiț de tip Loeschcke $X$ (fragmentar, se două păstrează două fragmente din capac). PI. VI/55. Nr. inv.: 139892. Micia 1979, castru, S X, carou 87, $1,90 \mathrm{~m} . \mathrm{Lp}=7 \mathrm{~cm} ; \mathrm{lp}=5,8 \mathrm{~cm} ; \mathrm{hp}=1,2 \mathrm{~cm}$. Pastă fină (Munsell 5YR 6/8, reddish yellow). Firnis parțial păstrat (Munsell 10R 4/8, weak red). Ardere primară incompletă. Tipar bivalv. Disc parțial păstrat, rotund, neted, delimitat de bordură printr-un cordon proeminent, care se îndreaptă spre cioc. Bordura lată, păstrează doi butoni. Sec. II p. Chr. Atelier provincial Dacia Superior (?). Inedit.

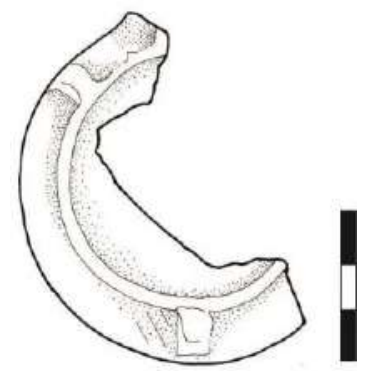

56. Opait de tip Loeschcke $X$ (fragment din capac). Pl. VI/56. Nr. inv.: 139881. Micia 1979, castru, S X, carou 77, partea inferioară a unei gropi. $\mathrm{Lp}=6,9 \mathrm{~cm} ; \mathrm{lp}=6,3 \mathrm{~cm} ; \mathrm{hp}=1,5 \mathrm{~cm}$. Pastă fină (Munsell 5YR 6/8, reddish yellow). Firnis de parțial păstrat (Munsell 2.5 YR 5/8, red). Ardere primară completă. Tipar bivalv. Disc rotund, ornamentat cu două mime tragice, prevăzut cu un orificiu de alimentare amplasat spre cioc, delimitat de bordură printr-un cordon care se îndreaptă spre cioc și formează un canal, parțial păstrat. Bordura lată păstrează un buton. Sec. II p. Chr. Atelier norditalic (?). Inedit.

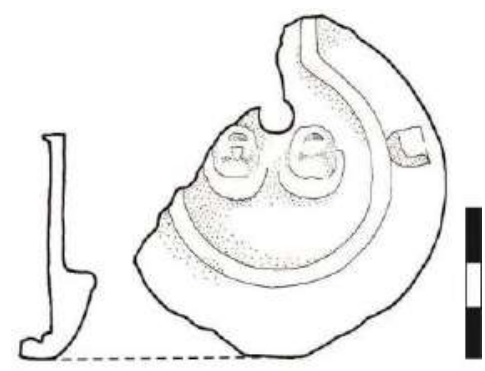


57. Opait de tip Loeschcke $X$ (fragment din capac). PI. VI/57. Nr. inv.: 338503. Micia 1982, castru, S XXIV, carou 7, $-0,80 \mathrm{~m} . \mathrm{Lp}=5,6 \mathrm{~cm} ; 1=$ $5,6 \mathrm{~cm} ; \mathrm{hp}=1,1 \mathrm{~cm}$. Pastă fină (Munsell 2.5YR 5/6, red). Firnis parțial păstrat (Munsell 2.5 YR 5/8, red). Ardere primară completă. Urme de mortar pe suprafața piesei. Tipar bivalv. Disc rotund, neted, cu un orificiu de alimentare în centru, delimitat de bordură printr-un cordon care se îndreaptă spre cioc și formează un canal. Bordură lată, prevăzută cu doi butoni dispuși aproximativ simetric. Sec. II p. Chr. (?). Atelier local Micia (?). Inedit.

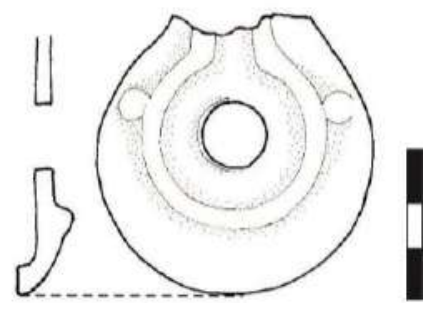

58. Opait de tip Loeschcke $X$ (fragment din capac si rezervor). Pl. VI/58. Nr. inv.: 338506. Micia 1983, castru, S XXV, carou 14, -0,50-0,80 m. Lp = $5,6 \mathrm{~cm} ; \mathrm{lp}=3,7 \mathrm{~cm} ; \mathrm{hp}=1,5 \mathrm{~cm}$. Pastă fină (Munsell 2.5YR 5/4, weak red). Firnis parțial păstrat (Munsell 10R 5/6, red). Ardere primară completă. Tipar bivalv. Disc parţial păstrat, rotund, neted, delimitat de bordură printr-un cordon proeminent, care se îndreaptă spre cioc şi formează un canal. Bordura lată păstrează un buton bifid. Cioc alungit (?). Rezervor tronconic. Sec. II p. Chr. Atelier nord-italic (?). Inedit.

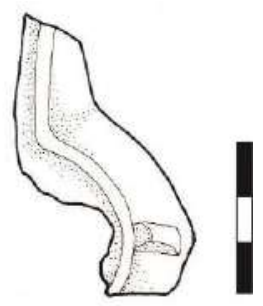

59. Opait de tip Loeschcke $\mathbf{X}$ (fragment din capac). Pl. VI/59. Nr. inv.: 338507. Micia 1982, castru, S XXIV, carou 3, $-0,25 \mathrm{~m}$. Lp $=4,5 \mathrm{~cm}$; lp $=2,9 \mathrm{~cm} ; \mathrm{hp}=0,9 \mathrm{~cm}$. Pastă fină (Munsell 7.5YR $8 / 6$, reddish yellow). Firnis parțial păstrat (Munsell 2.5YR 4/6, dark red). Ardere primară completă. Ardere secundară pe cioc, datorată utilizării. Tipar bivalv. Disc parțial păstrat, rotund (?) neted, delimitat de bordură printr-un cordon care se îndreaptă spre cioc, îl înconjoară și formează un canal. Bordura îngustă păstrează un buton. Cioc alungit, cu un orificiu de ardere, probabil în formă de vârf de săgeată arondat. Sec. II-III p. Chr. Atelier provincial Dacia Superior (?). Inedit.

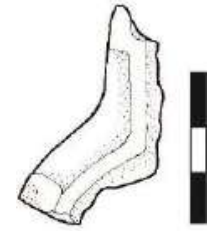

60. Opait de tip Loeschcke $\mathbf{X}$ (fragment din capac). Pl. VI/60. Nr. inv.: 157832. Micia 1976, castru, S I, carou 39, $-0,70 \mathrm{~m}$. Lp $=4 \mathrm{~cm} ; \mathrm{lp}=2,5$ cm. Pastă fină (Munsell 7.5YR 8/6, reddish yellow). Firnis parțial păstrat (Munsell 5YR 5/8, yellowish red). Ardere primară completă. Ardere secundară pe disc. Tipar bivalv. Disc parțial păstrat, rotund, neted, delimitat de bordură printr-un cordon proeminent. Bordura îngustă păstrează un buton. Sec. II-III p. Chr. Atelier provincial Dacia Superior (?). Inedit.

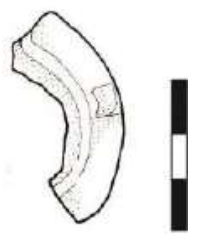

61. Opaiţ de tip Loeschcke X (fragment capac). PI. VI/61. Nr. inv.: 338538. Micia 1981, castru, S XVIII, carou 21, $-0,84 \mathrm{~m}$. Lp $=3,5 \mathrm{~cm} ; \mathrm{lp}=4,4$ cm. Pastă fină (Munsell 7.5YR 5/6, strong brown). Firnis parțial păstrat (Munsell 2.5YR 5/8, red). Ardere primară completă. Tipar bivalv. Disc parțial păstrat, rotund, uşor concav, delimitat de bordură printr-un cordon care se îndreaptă spre cioc, îl înconjoară și formează un canal prevăzut cu un mic orificiu de ventilație. Bordura îngustă păstrează un buton. Sec. II-III p. Chr. Atelier provincial Dacia Superior (?). Inedit.

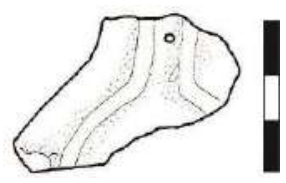

62. Opait de tip Loeschcke $\mathbf{X}$ (fragment din capac). Pl. VI/62. Fără nr. inv. Micia 1979, castru, $\mathrm{S} \mathrm{X}$, carou 74, $-1,50 \mathrm{~m}$. Lp = 3,7 cm; $1 \mathrm{p}=2,6 \mathrm{~cm}$. Pastă fină (Munsell 5YR 6/6, reddish yellow). Firnis parţial păstrat (Munsell 10 R4/6, red). Ardere primară completă. Tipar bivalv. Disc rotund (?) ușor concav, parțial păstrat, delimitat de bordură printr-un cordon proeminent, care se îndreaptă spre cioc și formează un canal. Bordura lată, păstrează un buton rotund. Sec. II p. Chr. Atelier provincial Dacia Superior (?). Inedit.

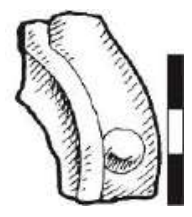


63. Opait de tip Loeschcke $X$ (fragment din capac). PI. VI/63. Nr. inv.: 338508. Micia 1976, castru, TR. $\mathrm{Lp}=2,6 \mathrm{~cm} ; \mathrm{lp}=2,1 \mathrm{~cm} ; \mathrm{hp}=0,8 \mathrm{~cm}$. Pastă fină (Munsell 10YR 7/4, very pale brown). Firnis parțial păstrat (Munsell 2.5YR 5/6, red). Ardere primară completă. Slabe urme de ardere secundară pe cordon. Tipar bivalv. Cordon proeminent, care se îndreaptă spre cioc şi formează un canal. Bordură lată, parțial păstrată. Sec. II-III p. Chr. Atelier nord-italic (?). Inedit.

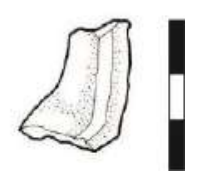

64. Opait, probabil de tip Loeschcke $X$ (fragment din cioc, rezervor și bază). Pl. VI/64. Nr. inv.: 338515. Micia 1978, castru, S XII, carou 88, passim. $\mathrm{Lp}=7,7 \mathrm{~cm} ; \mathrm{lp}=1,6 \mathrm{~cm} ; \mathrm{hp}=1,6 \mathrm{~cm}$. Pastă fină (Munsell 5YR 6/8, reddish yellow). Ardere primară completă. Ardere secundară pe cioc, datorată utilizării. Tipar bivalv. Cioc alungit, rotunjit, cu un orificiu de ardere (?) Rezervor tronconic. Bază dreaptă. Sec. II-III p. Chr. Atelier provincial Dacia Superior (?). Inedit.

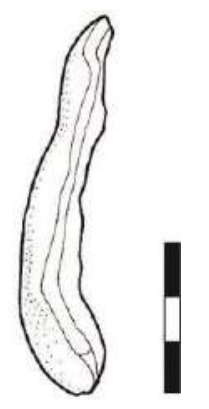

65. Opait de tip Loeschcke $\mathbf{X}$ (fragment din capac). Pl. VI/65. Nr. inv.: 131654. Micia 1977, castru, S II, carou 48, $-0,60 \mathrm{~m}$. Lp = 5,9 cm; lp = 3 $\mathrm{cm} ; \mathrm{hp}=1,6 \mathrm{~cm}$. Pastă fină (Munsell 7.5YR 7/8, reddish yellow). Firnis parțial păstrat (Munsell 5YR 5/8, yellowish red). Ardere primară completă. Tipar bivalv. Disc parțial păstrat, rotund (?) neted, delimitat de bordură printr-un cordon proeminent, care se îndreaptă spre cioc, îl înconjoară și formează un canal. Cioc alungit, cu un orificiu de ardere în formă de vârf de săgeată arondat. Sec. II p. Chr. Atelier nord-italic (?). Inedit.

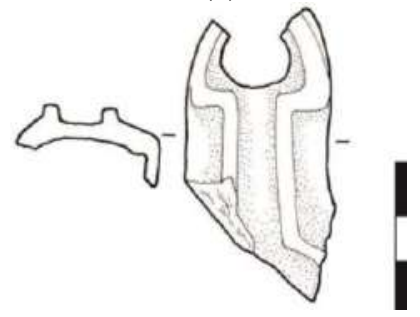

66. Opait de tip Loeschcke $\mathbf{X}$ (fragment din capac, rezervor și bază). PI. VI/66. Nr. inv.: 139882. Micia 1979, castru, S X, carou 65, $-1,70 \mathrm{~m}$. Lp = 4,9 cm; lp
$=4,5 \mathrm{~cm} ; \mathrm{hp}=2,8 \mathrm{~cm}$. Pastă fină (Munsell 5YR 7/8, reddish yellow). Firnis parțial păstrat (Munsell $2.5 \mathrm{YR} 5 / 6$, red). Ardere primară completă. Ardere secundară pe cioc datorată utilizării. Tipar bivalv. Disc parțial păstrat, rotund (?) neted, delimitat de bordură printr-un cordon, care se îndreaptă spre cioc, îl înconjoară și formează un canal. Bordură îngustă, parțial păstrată. Cioc alungit, cu un orificiu de ardere în formă de vârf de săgeată arondat. Rezervor tronconic. Bază ușor concavă, delimitată prin două caneluri fine, circulare, concentrice. Particularitate: canal incomplet perforat în vederea realizării unui orificiu de ventilație. Sec. II p. Chr. Atelier norditalic (?). Inedit.

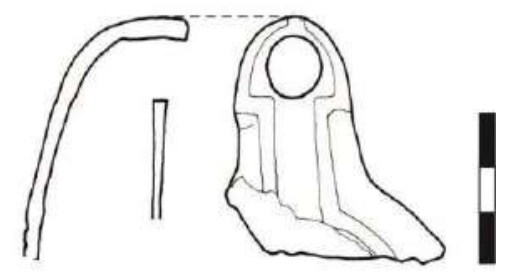

67. Opait de tip Loeschcke $\mathbf{X}$ (fragment din capac). Pl. VI/67. Nr. inv.: 139879. Micia 1976, castru, S I, carou 68, $-1,10 \mathrm{~m}$. Lp = 5,5 cm; lp = 3,4 $\mathrm{cm} ; \mathrm{hp}=0,7 \mathrm{~cm}$. Pastă fină (Munsell 5YR 7/6, reddish yellow). Firnis parțial păstrat (Munsell 5YR 5/8, yellowish red). Ardere primară completă. Ardere secundară pe cioc datorată utilizării. Ardere secundară pe disc şi bordură, la interior şi exterior. Tipar bivalv. Disc parțial păstrat, rotund (?) neted, delimitat de bordură printr-un cordon proeminent, care se îndreaptă spre cioc, îl înconjoară și formează un canal. Bordură lată, parțial păstrată. Cioc alungit, cu un orificiu de ardere în formă de vârf de săgeată arondat. Sec. II p. Chr. Atelier norditalic (?). Inedit.

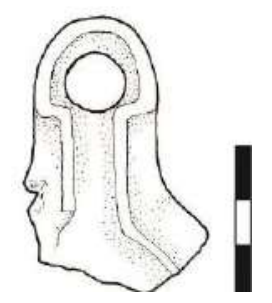

68. Opait de tip Loeschcke $\mathbf{X}$ (fragment din capac). Pl. VI/68. Nr. inv.: 139896. Micia 1978, castru, S III, carou 83, $-1,60-1,70 \mathrm{~m}$. Lp = 4,7 cm; $\mathrm{lp}=4,6 \mathrm{~cm} ; \mathrm{hp}=0,8 \mathrm{~cm}$. Pastă fină (Munsell 7.5YR 6/6, reddish yellow). Firnis parțial păstrat (Munsell 10R 4/6, red). Ardere primară completă. Ardere secundară pe cioc datorată utilizării. Tipar bivalv. Disc parțial păstrat, rotund (?) neted, delimitat de bordură printr-un cordon proeminent, care se îndreaptă spre cioc, îl înconjoară și formează un canal, prevăzut cu un mic orificiu de ventilație. Bordură lată, parțial păstrată, decorată cu 
incizii radiale. Cioc alungit, cu un orificiu de ardere. Sec. II p. Chr. Atelier provincial Dacia Superior (?). Inedit.

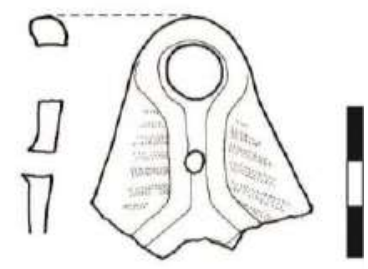

69. Opaiţ de tip Loeschcke $X$ (fragment cioc). PI. VI/69. Nr. inv.: 338534. Micia 1982, castru, S XXII, carou $9,-0,85 \mathrm{~m} . \mathrm{Lp}=3,5 \mathrm{~cm} ; \mathrm{lp}=3,6 \mathrm{~cm}$; hp $=3 \mathrm{~cm}$. Pastă fină (Munsell 5YR 6/8, reddish yellow). Ardere primară completă. Slabe urme de ardere secundară pe cioc datorată utilizării. Tipar bivalv. Cioc scurt, rotunjit cu un orificiu de ardere. Sec. II-III p. Chr. Atelier provincial Dacia Superior (?). Inedit.

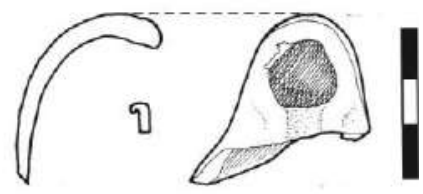

\section{Lămpi anepigrafice de tip Loeschcke IX sau Loeschcke X}

70. Opait de tip Loeschcke IX/X (fragment din ansă, capac și rezervor). Pl. VI/70. Nr. inv.: 338504. Micia 1979, castru, S XI, carou 1, $-1,35 \mathrm{~m}$. $\mathrm{Lp}=5 \mathrm{~cm} ; \mathrm{lp}=6,5 \mathrm{~cm} ; \mathrm{hp}=5,2 \mathrm{~cm}$. Pastă fină (Munsell 5YR 7/8, reddish yellow). Firnis parțial păstrat (Munsell 2.5YR 5/8, red). Ardere primară completă. Tipar bivalv. Disc parțial păstrat, rotund (?) concav, delimitat de bordură printr-un cordon proeminent. Bordură lată, parțial păstrată. Rezervor tronconic (?) Este prevăzut cu o ansă inelară, lată, cu două caneluri, atașată pe bordură și rezervor. Sec. II p. Chr. Atelier provincial Dacia Superior (?). Inedit.

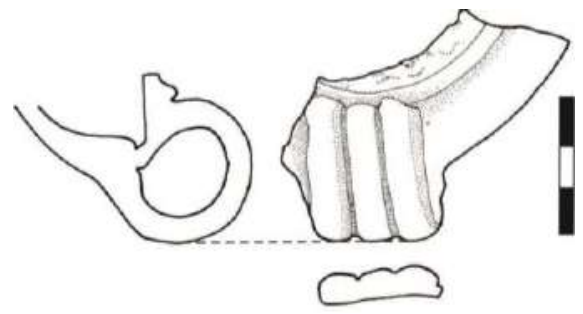

71. Opait de tip Loeschcke IX/X (fragment din capac, rezervor şi bază). PI. VI/71. Nr. inv.: 139889. Micia 1978, castru, S III, carou 83, $-1,90$ m. Lp = 3,7 cm; $1=6 \mathrm{~cm} ; \mathrm{h}=3,2 \mathrm{~cm}$. Pastă fină (Munsell 7.5YR 7/6, reddish yellow). Firnis parțial păstrat (Munsell 2.5YR 6/8, red). Ardere primară completă. Tipar bivalv. Disc parțial păstrat, rotund, neted, delimitat de bordură printr-un cordon. Bordură îngustă, parțial păstrată. Rezervor tronconic. Bază inelară, ușor concavă. Sec. II p. Chr. Atelier provincial Dacia Superior (?). Inedit.

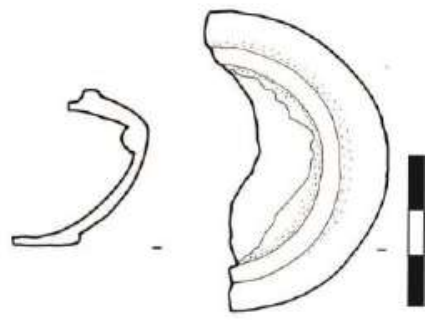

72. Opait de tip Loeschcke IX/X (fragment din capac și rezervor, cu dimensiuni de 4,6 × 2,5 cm). Pl. VII/72. Nr. inv.: 139895. Micia 1977, castru, S II, carou $56,-1,46 \mathrm{~m} ; \mathrm{hp}=1,9 \mathrm{~cm}$. Pastă fină (Munsell 5YR 7/8 reddish yellow). Firnis parțial păstrat (Munsell 5YR 5/6, yellowish red). Ardere primară completă. Tipar bivalv. Disc parțial păstrat, rotund (?), neted, delimitat de bordură printr-un cordon. Bordura îngustă păstrează un buton. Rezervor tronconic (?). Sec. II p. Chr. Atelier provincial Dacia Superior (?) Inedit.

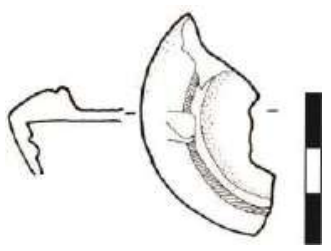

73. Opaiţ de tip Loeschcke IX/X (fragmentar, se păstrează un fragment din capac cu dimensiuni de $3,3 \times 2,5 \mathrm{~cm}$ şi un fragment din partea inferioară a ciocului, cu dimensiuni de 4,4 $42 \mathrm{~cm})$. PI. VII/73. Nr. inv.: 338505. Micia 1985, castru, S XXVII, passim, $-0,70$ m. Pastă fină (Munsell 5YR 6/8, reddish yellow). Firnis parțial păstrat (Munsell 10R $5 / 8$, red). Ardere primară incompletă. Ardere secundară pe cioc datorată utilizării. Tipar bivalv. Disc parțial păstrat, rotund (?), neted, cu un orificiu de alimentare în centru, delimitat de bordură printrun cordon. Bordura îngustă păstrează un buton. Cioc, probabil alungit, rotunjit, cu un orificiu de ardere. Sec. II-III p. Chr. Atelier local Micia (?). Inedit.
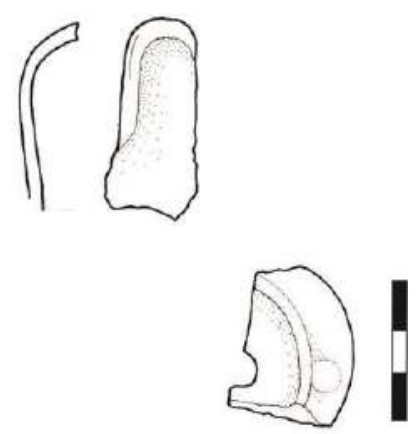
74. Opait de tip Loeschcke IX/X (fragment din capac, rezervor și bază, cu dimensiuni de $7 \times 3,7$ cm). Pl. VII/74. Nr. inv.: 139890. Micia 1979, castru, S III, carou 49, $-0,60 \mathrm{~m} ; \mathrm{h}=3,3 \mathrm{~cm}$. Pastă fină (Munsell 10YR 7/6, yellow). Firnis parțial păstrat (Munsell 7.5R 4/6, strong brown). Ardere primară completă. Ardere secundară pe rezervor și bază. Tipar bivalv. Cordon slab profilat. Bordură lată, parțial păstrată. Rezervor tronconic. Bază concavă. Sec. II p. Chr. Atelier provincial Dacia Superior (?). Inedit.
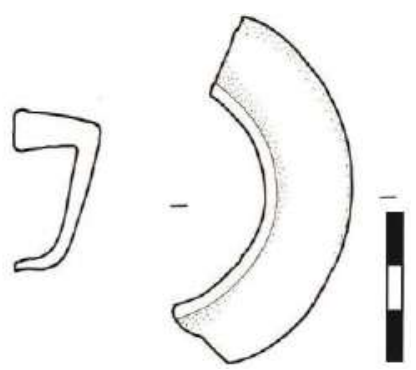

75. Opaiț de tip Loeschcke IX/X (fragmentar, se păstrează un fragment din bordură cu rezervor și un alt fragment din rezervor cu bază, cu dimensiuni cuprinse între 3,2-4,5 cm). Pl. VII/75. Nr. inv.: 157832. Micia 1976, castru, S I, carou 39, $-0,70 \mathrm{~m}$. Pastă fină (Munsell 10YR 7/3, very pale brown). Ardere secundară pe cioc datorată utilizării. Tipar bivalv. Bordură lată, parțial păstrată. Rezervor tronconic. Bază ușor concavă. Sec. II-III p. Chr. Atelier provincial Dacia Superior (?). Inedit.

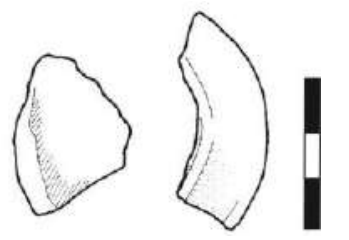

76. Opait de tip Loeschcke IX/X (fragment din capac). Pl. VII/76. Nr. inv.: 139897. Micia 1979, castru, S III, carou 58, $-0,90 \mathrm{~m}$. Lp = 5,2 cm; lp = $3,9 \mathrm{~cm} ; \mathrm{hp}=1 \mathrm{~cm}$. Pastă fină (Munsell 7.5YR 7/4, pink). Firnis parţial păstrat (Munsell 10R 5/8, red). Ardere primară completă. Tipar bivalv. Disc rotund, neted, cu un orificiu de alimentare în centru, delimitat de bordură printr-un cordon proeminent. Bordura îngustă, decorată cu două incizii dispuse radial păstrează un buton. Sec. II p. Chr. Atelier local Micia (?). Inedit.

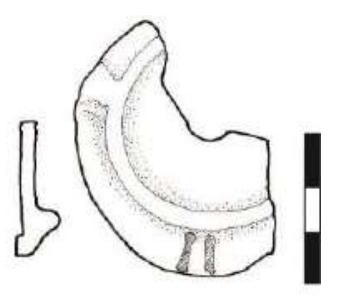

77. Opaiț de tip Loeschcke IX/X (fragment din capac). Pl. VII/77. Nr. inv.: 139884. Micia 1979, castru, S X, carou 83, $-1,80 \mathrm{~m}$. Lp = 4,5 cm; $1=5,4$ $\mathrm{cm} ; \mathrm{hp}=1,1 \mathrm{~cm}$. Pastă fină (Munsell 7.5YR 8/4, pink). Firnis parțial păstrat (Munsell 5YR 5/8, yellowish red). Ardere primară incompletă. Tipar bivalv. Disc rotund, neted, cu un orificiu de alimentare în centru, delimitat de bordură printr-un cordon. Bordura lată păstrează doi butoni bifizi. Sec. II p. Chr. Atelier nord-italic (?). Inedit.

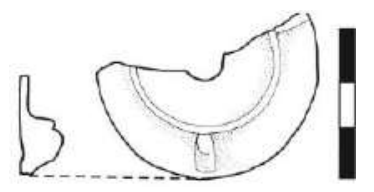

78. Opait de tip Loeschcke IX/X (fragment din capac). Pl. VII/78. Fără nr. inv. Micia 1976, castru, $\mathrm{S}$ 1, carou 1, $-1,50-1,70 \mathrm{~m}$. Lp = 3,7 cm; lp = 4,8 cm. Pastă fină (Munsell 7.5YR 5/3, brown). Disc parţial păstrat, rotund, neted, cu un orificiu de alimentare în centru (?), delimitat de bordură printrun cordon. Bordura îngustă păstrează un buton. Sec. II p. Chr. Atelier provincial Dacia Superior (?). Inedit.

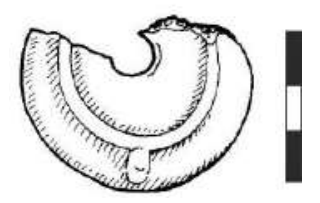

79. Opait de tip Loeschcke IX/X (fragment din capac). Pl. VII/79. Nr. inv.: 157763. Micia 1980, castru, S III, carou 18, $-0,80 \mathrm{~m}$. Lp = 3,5 cm; lp = $3,6 \mathrm{~cm}$. Pastă fină (Munsell 7.5YR 7/2, pinkish gray). Firnis parțial păstrat (Munsell 5YR 5/6, yellowish red). Ardere primară completă. Ardere secundară pe bordură. Tipar bivalv. Disc parțial păstrat, rotund, neted, cu un orificiu de alimentare în centru, delimitat de bordură printr-un cordon. Bordura lată păstrează doi butoni. Sec. II p. Chr. Atelier local Micia (?). Inedit.

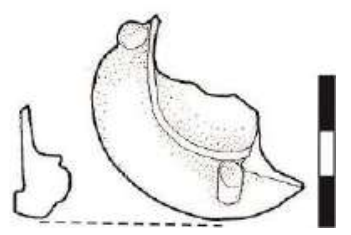

80. Opaiț de tip Loeschcke IX/X (fragmentar, se păstrează două fragmente din capac și un fragment din rezervor cu bază). PI. VII/80. Nr. inv.: 131654. Micia 1977, castru, S II, carou 48, -0,60 m. Lp = $3,2 \mathrm{~cm} ; 1 \mathrm{p}=5 \mathrm{~cm}$. Pastă fină (Munsell 7.5YR 6/6, reddish yellow). Firnis parțial păstrat (Munsell 2.5YR 5/8, red). Ardere primară completă. Tipar bivalv. Disc parțial păstrat, rotund, neted, delimitat de bordură printr-un cordon. Bordura îngustă păstrează doi butoni. Rezervor tronconic (?). Bază 
ușor concavă (?). Sec. II p. Chr. Atelier local Micia (?). Inedit.

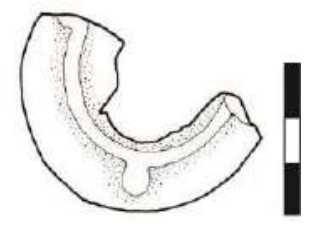

81. Opait de tip Loeschcke IX/X (fragment cioc). PI. VII/81. Nr. inv.: 338516. Micia 1982, castru, S XXII, carou $1,-0,80 \mathrm{~m} . \mathrm{Lp}=3,5 \mathrm{~cm} ; \mathrm{lp}=2,7 \mathrm{~cm}$; $\mathrm{hp}=3,5 \mathrm{~cm}$. Pastă fină (Munsell 5YR 5/6, yellowish red). Ardere primară completă. Ardere secundară pe cioc datorată utilizării. Tipar bivalv. Cioc scurt, rotunjit, cu un orificiu de ardere. Sec. II-III p. Chr. Atelier local Micia (?). Inedit.

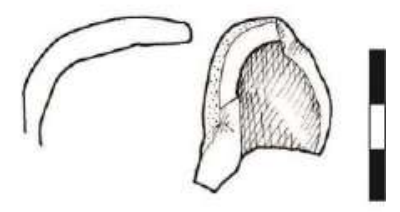

82. Opait de tip Loeschcke IX/X (fragment cioc). Pl. VII/82. Nr. inv.: 124368. Micia 1976, castru, S I. Lp = $4 \mathrm{~cm} ; \mathrm{lp}=2,4 \mathrm{~cm} ; \mathrm{hp}=2,3 \mathrm{~cm}$. Pastă fină (Munsell 7.5YR 6/4, light brown). Firnis parțial păstrat (Munsell 2.5 YR 5/4, weak red). Ardere primară completă. Ardere secundară pe cioc datorată utilizării. Tipar bivalv. Cioc rotunjit, cu un orificiu de ardere. Sec. II-III p. Chr. Atelier provincial Dacia Superior (?). Inedit.

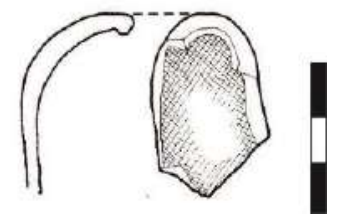

83. Opait de tip Loeschcke IX/X (fragment din capac, cu dimensiuni de 4,5 $\times 3 \mathrm{~cm})$. PI. VII/83. Nr. inv.: 338512. Micia 1979, castru, S X, carou 53, $-0,55$ m. Pastă fină (Munsell 5YR 6/6, reddish yellow). Firnis parțial păstrat (Munsell 2.5 YR 4/6, dark red). Ardere primară completă. Tipar bivalv. Disc parțial păstrat, rotund, neted, delimitat de bordură printr-un cordon. Bordură lată, parţial păstrată. Sec. II-III p. Chr. Atelier provincial Dacia Superior (?). Inedit.

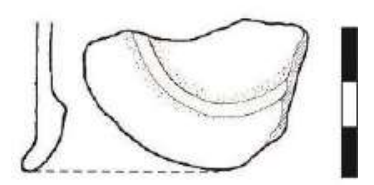

84. Opaiț de tip Loeschcke IX/X (fragment din capac, cu dimensiuni de 4,1 $\times 3 \mathrm{~cm}$ ). Pl. VII/84. Nr. inv.: 338513. Micia 1979, castru, S X, carou 89, $-1,30$ m. Pastă fină (Munsell 7.5YR 5/4, brown).
Firnis parțial păstrat (Munsell 2.5 YR 4/6, dark red). Ardere primară incompletă. Tipar bivalv. Disc parțial păstrat, rotund, neted, delimitat de bordură printr-un cordon proeminent. Bordură lată, parțial păstrată. Sec. II p. Chr. Atelier provincial Dacia Superior (?). Inedit.

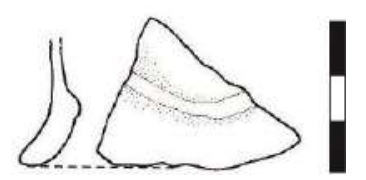

85. Opait de tip Loeschcke IX/X (fragment din capac, cu dimensiuni de 5,8 $82 \mathrm{~cm}$ ). PI. VII/85. Nr. inv.: 338509. Micia 1981, castru, S XX, carou 7, -1,00 m. Pastă fină (Munsell 7.5YR 6/6, reddish yellow). Firnis parțial păstrat (Munsell 5 YR 5/8, yellowish red). Ardere primară completă. Ardere secundară pe bordură. Tipar bivalv. Disc parțial păstrat, rotund, neted, delimitat de bordură printr-un cordon proeminent. Bordura lată, decorată atât cu o rețea de incizii cât și cu incizii radiale, păstrează un buton. Sec. II p. Chr. Atelier provincial Dacia Superior (?). Inedit.

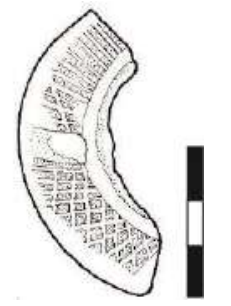

86. Opait de tip Loeschcke IX/X (fragment din capac şi rezervor, cu dimensiuni de 5,8 $\times 1,5 \mathrm{~cm}$ ). $\mathbf{P l}$. VII/86. Nr. inv.: 338510. Micia 1981, castru, S XIX, carou 4, -0,65 m. Pastă fină (Munsell 7.5YR 6/6, reddish yellow). Firnis parțial păstrat (Munsell 2.5 YR 5/6, red). Ardere primară completă. Ardere secundară pe bordură. Tipar bivalv. Disc parțial păstrat, rotund, neted, delimitat de bordură printr-un cordon. Bordura îngustă păstrează doi butoni. Rezervor tronconic (?). Sec. II p. Chr. Atelier provincial Dacia Superior (?). Inedit.

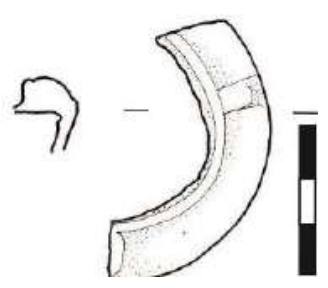

87. Opait de tip Loeschcke IX/X (fragment din capac, cu dimensiuni de 5,7 × 1,8 cm). Pl. VII/87. Nr. inv.: 338511. Micia 1978, castru, S III, carou 83. Pastă fină (Munsell 7.5YR 6/6, reddish yellow). Firnis parțial păstrat (Munsell 5YR 5/6, yellowish red). Ardere primară completă. Ardere secundară pe bordură. Tipar bivalv. Disc parțial păstrat, rotund, neted, delimitat de bordură printr-un cordon. Bordura lată, păstrează un buton, care pornește din 
cordon. Sec. II-III p. Chr. Atelier provincial Dacia Superior (?). Inedit.

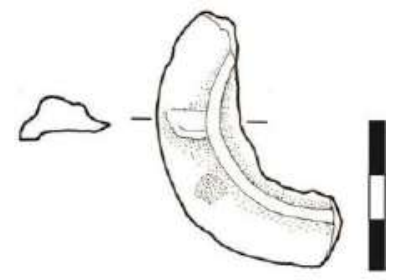

88. Opait de tip Loeschcke IX/X (fragment din capac, cu dimensiuni de 3,7 × 2,4 cm). Pl. VII/88. Nr. inv.: 338514. Micia 1982, castru, S XXIV, carou 6, -0,70 m. Pastă fină (Munsell 5YR 5/6, yellowish red). Firnis parțial păstrat (Munsell 5YR $5 / 6$, yellowish red). Ardere primară completă. Tipar bivalv. Disc parțial păstrat, rotund, neted, delimitat de bordură printr-un cordon proeminent. Bordura lată, păstrează un buton bifid. Sec. II-III p. Chr. Atelier provincial Dacia Superior (?). Inedit.

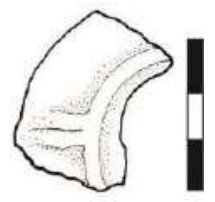

89. Opait de tip Loeschcke IX/X (fragmentar, se păstrează partea inferioară). PI. VII/89. Nr. inv.: 131657. Micia 1978, castru, S III, carou 84, $-1,70$ m; colţ de NV, groapă. L = 7,2 cm; $1=4,8 \mathrm{~cm} ; \mathrm{hp}=$ $2,4 \mathrm{~cm}$. Pastă fină (Munsell 5YR 7/4, pink). Firnis parțial păstrat (Munsell 5 YR 4/6, yellowish red). Ardere primară completă. Slabe urme de ardere secundară pe rezervor şi bază. Tipar bivalv. Cioc alungit, rotunjit, cu un orificiu de ardere. Rezervor tronconic. Bază uşor concavă. Sec. II p. Chr. Atelier provincial Dacia Superior (?). Inedit.

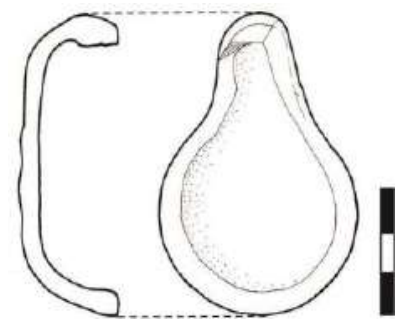

90. Opait bilychnis de tip Loeschcke IX/X (fragment din cioc, rezervor și bază). PI. VII/90. Nr. inv.: 157757. Micia 1980, castru, S III, carou 9, $-0,50 \mathrm{~m}$. Lp = 6,6 cm; lp = 4,2 cm; hp = 2,9 cm. Pastă fină (Munsell 5YR 6/8, reddish yellow). Ardere primară completă. Slabe urme de ardere secundară pe rezervor și bază Tipar bivalv. Cioc alungit, rotunjit, cu două orificii de ardere. Rezervor tronconic. Bază concavă. Sec. II-III p. Chr. Atelier provincial Dacia Superior (?). Inedit.

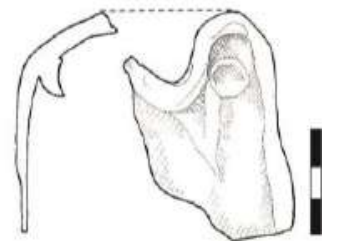

91. Opaiţ de tip Loeschcke IX/X (fragment din partea inferioară a ciocului cu rezervor și bază). Pl. VII/91. Nr. inv.: 338517. Micia 1976, castru, S I, carouri 62-71. Lp = $4 \mathrm{~cm} ; \mathrm{lp}=4,5 \mathrm{~cm} ; \mathrm{hp}=2,5 \mathrm{~cm}$. Pastă fină (Munsell 5YR 6/6, reddish yellow). Firnis parțial păstrat (Munsell 2.5 YR 5/8, red). Ardere primară completă. Slabe urme de ardere secundară pe cioc și rezervor. Tipar bivalv. Cioc alungit (?) cu un orificiu de ardere. Rezervor tronconic (?). Bază ușor concavă, delimitată prin două caneluri fine circulare, concentrice. Sec. II p. Chr. Atelier nord-italic (?). Inedit.
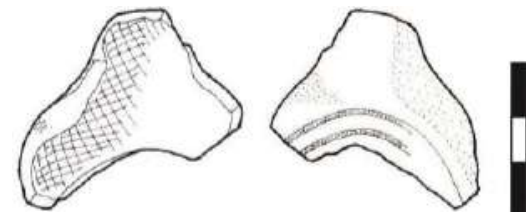

92. Opait de tip Loeschcke IX/X (fragment din partea inferioară a ciocului cu bază). PI. VII/92. Nr. inv.: 338518. Micia 1979, castru, S X, carou 63, $1,80 \mathrm{~m} . \mathrm{Lp}=3,3 \mathrm{~cm} ; 1 \mathrm{p}=2,9 \mathrm{~cm}$. Pastă fină (Munsell 10YR 5/6, yellowish brown). Firnis parțial păstrat (Munsell 7.5 YR 5/8, strong brown). Ardere primară completă. Slabe urme de ardere secundară pe partea inferioară a ciocului. Tipar bivalv. Cioc alungit (?), cu un orificiu de ardere. Bază ușor concavă, delimitată prin două caneluri fine, circulare, concentrice. Sec. II p. Chr. Atelier provincial Dacia Superior (?). Inedit.
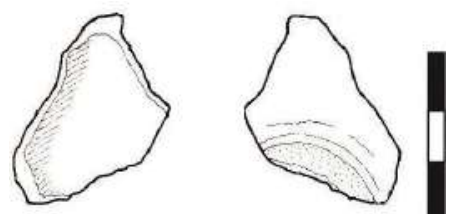

93. Opait de tip Loeschcke IX/X (fragmentar, se păstrează două fragmente din rezervor cu bază, cu dimensiuni de 4,8 $\times$ 4,7 cm). Pl. VII/93. Nr. inv.: 157755. Micia 1980, castru, S III, carou 22, $-0,60$ $\mathrm{m} ; \mathrm{hp}=2,1 \mathrm{~cm}$. Pastă fină (Munsell 7.5YR 7/6, reddish yellow). Ardere primară completă. Tipar bivalv. Rezervor tronconic. Bază concavă. Sec. IIIII p. Chr. Atelier provincial Dacia Superior (?). Inedit.

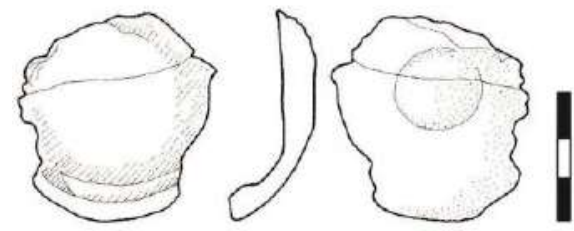




\section{Lămpi tubulare}

94. Opait de tip Alicu XI (fragment cioc, cu dimensiuni de $11 \times 5,3 \mathrm{~cm})$. Pl. VII/94. Nr. inv.: 338535. Micia 1981, castru, S XVII, $-1,25$ m. Pastă fină (Munsell 7.5YR 6/4, light brown). Firnis parțial păstrat (Munsell 5 YR 4/6, yellowish red). Ardere primară completă. Ardere secundară pe cioc datorată utilizării. Roata olarului. Rezervor parțial păstrat, de formă tubular - circulară, cu un orificiu de ventilație. Ciocul scurt păstrează un orificiu de ardere. Sec. II p. Chr. Atelier provincial Dacia Superior (?). Inedit.

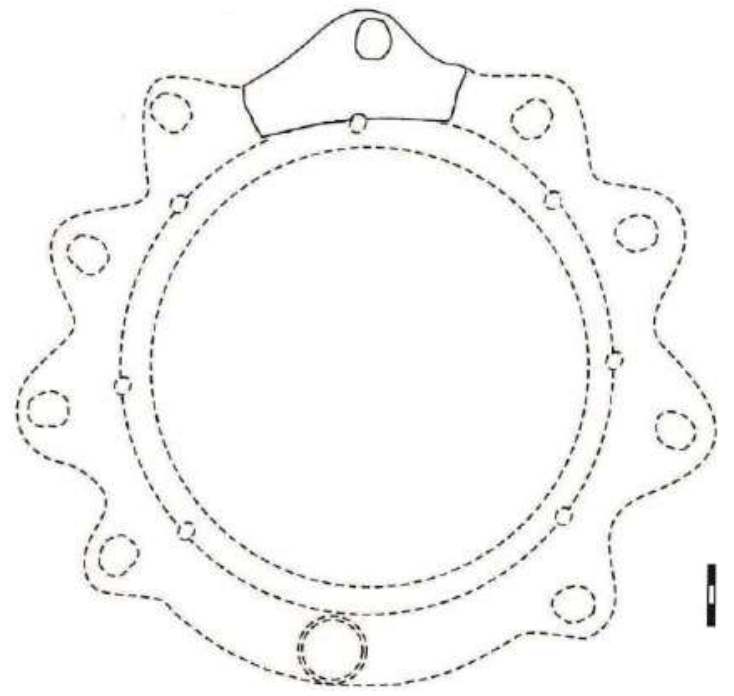

Lămpi nedeterminabile ca tip

95. Opait nedeterminabil ca tip (fragment din capac, cioc şi rezervor). Pl. VIII/95. Nr. inv.: 338532. Micia 1981, castru, S XVII, $-1,25 \mathrm{~m} . \mathrm{L}=8$ $\mathrm{cm} ; \mathrm{lp}=2,9 \mathrm{~cm} ; \mathrm{hp}=2,8 \mathrm{~cm}$. Pastă fină (Munsell 5YR 5/8, yellowish red). Firnis parțial păstrat (Munsell 7.5 YR 5/8, strong brown). Ardere primară completă. Ardere secundară pe cioc datorată utilizării. Ardere secundară pe rezervor şi bază. Tipar bivalv. Bordură lată, înclinată. Cioc alungit cu un arzător. Rezervor circular. Sec. II p. Chr. Atelier provincial Dacia Superior (?). Inedit.

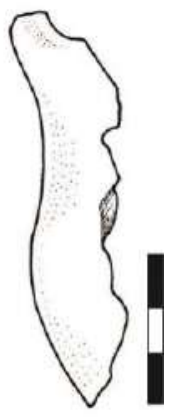

96. Opaiț nedeterminabil ca tip (fragmentar, se păstrează trei fragmente din partea inferioară a ciocului și un fragment din ansă cu dimensiuni cuprinse între 1,6-5 cm). Pl. VIII/96. Nr. inv: 338519. Micia 1982, castru, S XXII, carou 2, $-1,52$ m. Pastă fină (Munsell 10YR 7/4, very pale brown). Firnis parţial păstrat (Munsell 5 YR 5/8, yellowish red). Ardere primară completă. Tipar bivalv. Cioc, probabil, alungit, rotunjit. Ansa, probabil în formă de palmeta, prevăzută cu apucătoare dorsală. Sec. II p. Chr. Atelier provincial Dacia Superior (?). Inedit.

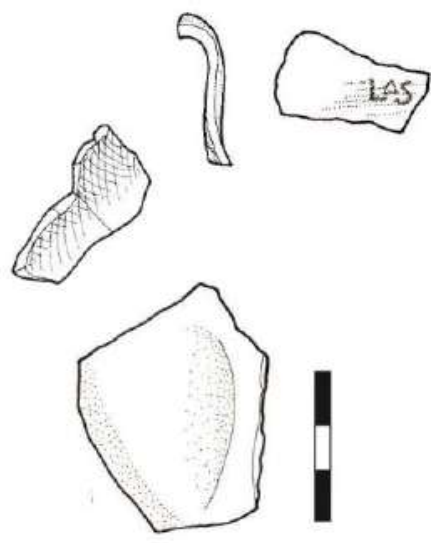

97. Opaiț nedeterminabil ca tip (fragmentar, se păstrează ansa, cu dimensiuni de 5,9 × 3,7 cm). Pl. VIII/97. Nr. inv.: 338520. Micia 1983, castru, S XXV, carou 25, $-0,50 \mathrm{~m}$. Pastă fină (Munsell 10YR $7 / 4$, very pale brown). Firnis parțial păstrat (Munsell 2.5 YR 4/6, dark red). Ardere primară completă. Tipar bivalv. Ansa în formă de palmeta cu apucătore dorsală, prevăzută cu un orificiu circular; este bogat decorată. Câmpul ansei este împărțit în patru lobi, aceștia fiind decorați cu câte două rozete fiecare. În centru, o profilatură bine pronunțată, prevăzută cu rozetă în partea superioară. Ansa se termină spre vârf cu buton profilat. Sec. II-III p. Chr. Atelier provincial Dacia Superior (?). Inedit.
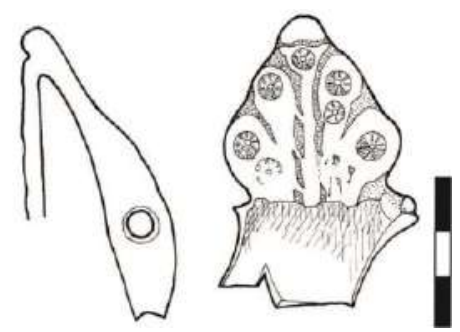
98. Opait nedeterminabil ca tip (fragment din capac). PI. VIII/98. Nr. inv.: 338521. Micia 1982, castru, S XXII, carou 10, $-0,75 \mathrm{~m} ; \mathrm{Lp}=3,8 \mathrm{~cm}$; lp $=3,6 \mathrm{~cm} ; \mathrm{hp}=0,8 \mathrm{~cm}$. Pastă fină (Munsell 5YR 8/4, pink). Glazură plumbiferă (Munsell 2.5 Y 5/6, light olive brown). Ardere primară completă. Tipar bivalv. Se păstrează un fragment din capac, prevăzut cu un orificiu de alimentare, decorat cu incizii radiale. Sec. II p. Chr. Atelier provincial Ampelum (?). Inedit.

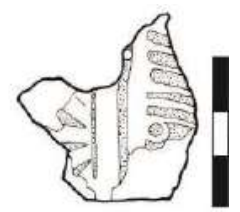

99. Opait nedeterminabil ca tip (fragment din partea inferioară a ciocului, cu dimensiuni de $4,1 \times$ 2 cm). Pl. VIII/99. Nr. inv.: 338528. Micia 1977, castru, S II, carou 78. Pastă fină (Munsell 7.5YR 7/4, pink). Firnis parțial păstrat (Munsell 7.5 Y 4/6, strong brown). Ardere primară completă. Ardere secundară pe cioc datorată utilizării. Tipar bivalv. Cioc rotunjit, probabil, cu un orificiu de ardere. Sec. II-III p. Chr. Atelier provincial Dacia Superior (?). Inedit.

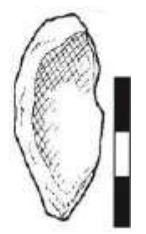

100. Opaiț nedeterminabil ca tip (fragment din partea inferioară a ciocului cu dimensiuni de $3,5 \times$ 2,4 cm). Pl. VIII/100. Nr. inv.: 338529. Micia 1979, castru, S X, carou $50,-1.00$ m. Pastă fină (Munsell 7.5YR 6/4, light brown). Firnis parțial păstrat (Munsell 2.5 Y 4/6, dark red). Ardere primară completă. Tipar bivalv. Cioc rotunjit, probabil, cu un orificiu de ardere. Sec. II-III p. Chr. Atelier provincial Dacia Superior (?). Inedit.

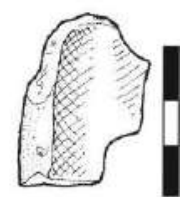

101. Opaiț nedeterminabil ca tip (fragment din partea inferioară a ciocului, cu dimensiuni de $3,4 \times$ $2 \mathrm{~cm}$ ). PI. VIII/101. Nr. inv.: 338530. Micia 1979, castru, S X, carou 76, $-1,60 \mathrm{~m} ; \mathrm{hp}=2,2 \mathrm{~cm}$. Pastă fină (Munsell 7.5YR 6/4, light brown). Firnis parțial păstrat (Munsell 2.5 Y 5/8, red). Ardere primară completă. Tipar bivalv. Cioc rotunjit, probabil, cu un orificiu de ardere. Sec. II p. Chr. Atelier provincial Dacia Superior (?). Inedit.

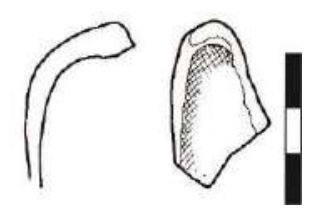

102. Opaiț nedeterminabil ca tip (fragment din partea inferioară a ciocului, cu dimensiuni de 2,8 $\times$ 2,4 cm). Pl. VIII/102. Nr. inv.: 338531. Micia 1977, castru, S II, carou 4, -1,15 m. Pastă fină (Munsell 2.5YR 6/8, red). Ardere primară completă. Ardere secundară pe cioc datorată utilizării. Tipar bivalv. Cioc rotunjit, probabil, cu un orificiu de ardere. Sec. II-III p. Chr. Atelier local Micia (?). Inedit.

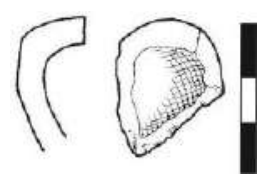

103. Opait nedeterminabil ca tip (fragment din bază cu rezervor, cu dimensiuni de 5,3 × 1,7 cm). PI. VIII/103. Nr. inv.: 338522. Micia 1982, castru, S XXII, carou 2, $-1,52 \mathrm{~m} ; \mathrm{hp}=1,6 \mathrm{~cm}$. Pastă fină (Munsell 5YR 5/8, yellowish red). Ardere primară completă. Ardere secundară pe bază. Tipar bivalv. Rezervor tronconic (?). Bază uşor concavă. Sec. II p. Chr. Atelier local Micia (?). Inedit.

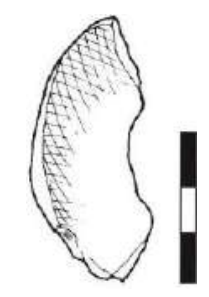

104. Opaiț nedeterminabil ca tip (fragment din bază cu rezervor). PI. VIII/104. Nr. inv.: 338523. Micia 1979, castru, S X, carou 53, $-0,55 \mathrm{~m}$. Lp = $3,3 \mathrm{~cm} ; \mathrm{lp}=4,1 \mathrm{~cm}$. Pastă fină (Munsell 10YR 5/4, yellowish brown). Glazură plumbiferă (Munsell 7.5 Y 3/4, dark brown). Ardere primară completă. Tipar bivalv. Rezervor tronconic. Bază uşor concavă, delimitată prin două caneluri circulare concentrice. Sec. II-III p. Chr. Atelier provincial Ampelum (?). Inedit.

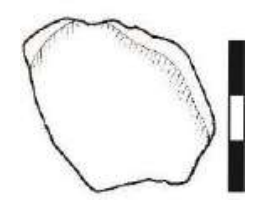

105. Opaiț nedeterminabil ca tip (fragment din bază cu rezervor, cu dimensiuni de 5,5 × 2,4 cm). Pl. VIII/105. Nr. inv.: 139883. Micia 1979, castru, S X, carou 73, $-1,50 \mathrm{~m} ; \mathrm{hp}=2,4 \mathrm{~cm}$. Pastă fină 
(Munsell 7.5YR 6/4, light brown). Ardere primară completă. Tipar bivalv. Rezervor tronconic. Bază ușor concavă, delimitată prin două caneluri fine, circulare, concentrice. Sec. II p. Chr. Atelier provincial Dacia Superior (?). Inedit.

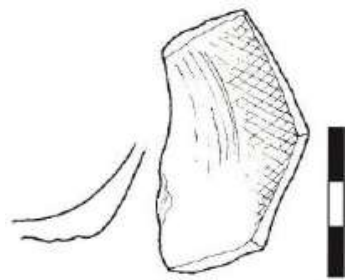

106. Opait nedeterminabil ca tip (fragment din bază cu rezervor, cu dimensiuni de 4,8 $\times 3,7 \mathrm{~cm}$ ). Pl. VIII/106. Nr. inv.: 139894. Micia 1979, castru, S III, carou 49, $-0,60 \mathrm{~m} ; \mathrm{hp}=3,7 \mathrm{~cm}$. Pastă fină (Munsell 7.5YR 6/3, light brown). Firnis parțial păstrat (Munsell 7.5 Y 6/8, reddish yellow). Ardere primară completă. Tipar bivalv. Rezervor tronconic. Bază uşor concavă, delimitată printr-o profilatură circulară, pronunțată. Sec. II-III p. Chr. Atelier provincial Dacia Superior (?). Inedit.

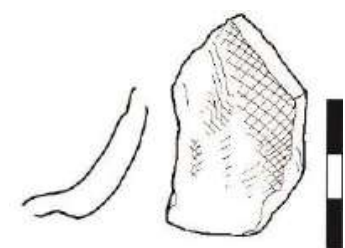

107. Opaiț nedeterminabil ca tip (fragment din bază cu rezervor, cu dimensiuni de 4,7 ×2,6 cm). PI. VIII/107. Nr. inv.: 338524. Micia 1978, castru, S III, carou $71,-1,15 \mathrm{~m} ; \mathrm{hp}=2,6 \mathrm{~cm}$. Pastă fină (Munsell 2.5Y 7/4, pale yellow). Firnis parțial păstrat (Munsell 2.5 Y 4/6 dark red). Ardere primară completă. Tipar bivalv. Rezervor tronconic. Bază uşor concavă. Sec. II p. Chr. Atelier Moesia Inferior (?). Inedit.

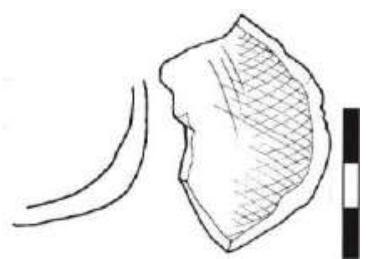

108. Opaiţ nedeterminabil ca tip (fragment din bază cu rezervor, cu dimensiuni de $4 \times 2,4 \mathrm{~cm})$. $\mathbf{P l}$. VIII/108. Nr. inv.: 338525. Micia 1981, castru, S XIX, carou 4, $-0,90 \mathrm{~m} ; \mathrm{hp}=2,2 \mathrm{~cm}$. Pastă fină (Munsell 5Y 6/8, reddish yellow). Ardere primară completă. Tipar bivalv. Rezervor tronconic. Bază ușor concavă. Sec. II p. Chr. Atelier local Micia (?). Inedit.

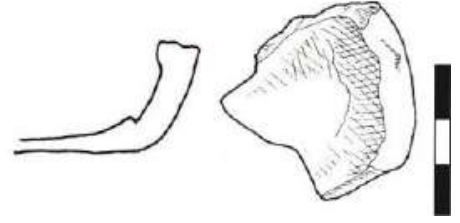

109. Opait nedeterminabil ca tip (fragment din rezervor, cu dimensiuni de $3 \times 2,5 \mathrm{~cm})$. $\mathbf{P l}$. VIII/109. Nr. inv.: 338526. Micia 1979, castru, S III, carou 47, $-0,60 \mathrm{~m}$. Pastă fină (Munsell 7.5YR $5 / 4$, brown). Ardere primară completă. Slabe urme de ardere secundară. Tipar bivalv. Rezervor tronconic. Sec. II-III p. Chr. Atelier provincial Dacia Superior (?). Inedit.

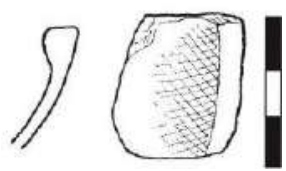

110. Opait nedeterminabil ca tip (fragment din bază cu rezervor, cu dimensiuni de 2,3 $\times 2 \mathrm{~cm}$ ). $\mathbf{P l}$. VIII/110. Nr. inv.: 338527. Micia 1977, castru, S II, carou 48. Pastă fină (Munsell 7.5YR 6/6, reddish yellow). Firnis parțial păstrat (Munsell 5YR 5/6, yellowish red). Ardere primară completă. Tipar bivalv. Rezervor tronconic. Bază ușor concavă. Sec. II-III p. Chr.? Atelier provincial Dacia Superior (?). Inedit.

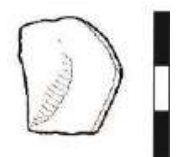

111. Tipar de opaiț (fragment din valva superioară, rebut). PI. VIII/111. Nr. inv.: 124507. Micia 1976, castru, S I, carou 65, 2, $-1,00 \mathrm{~m}$. Lp = $6 \mathrm{~cm} ; 1 \mathrm{p}=3,8 \mathrm{~cm} ; \mathrm{h}=1,6 \mathrm{~cm}$. Pastă fină (Munsell 5YR 5/4, reddish brown). Ardere primară completă. Mulaj. Rebut. Se păstrează un fragment din valva superioară a unui tipar pentru opaițe de tip Loeschcke IX. Sec. II p. Chr. Atelier local Micia (?). Inedit.

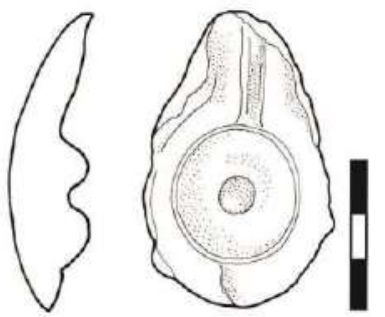


BIBLIOGRAFIE

Corpora de inscripții

CIL

IDR II

IDR III/6

\section{Alburnus Maior III}

Alicu 1976

Alicu 1979

Alicu 1985

Alicu 1994

Alicu 2006

Alram-Stern 1989

Ackner, Müller 1865

Antique Bronzes in Romania

Băluţă 1961

Bălută 1965

Băluţă 1977

Bălută 1979

Băluţă 1983

Băluță 1989

Băluță 1996

Băluță 1999

Băluță 2003

Bărcăcilă 1932

Bărcăcilă 1934

Bărbulescu, Cătinaș 1992

Bărbulescu 1994

Bailey 1980

Bailey 1988
Corpus Inscriptionum Latinarum, 17 vol., Berlin, 1863 sqq.

I. I. Russu (red.), Inscriptiones Daciae Romanae; Inscripţiile Daciei Romane, II, Bucureşti, 1975

C. L. Băluţă, Inscripţiile Daciei Romane. Instrumentus domesticum Bucureşti, III/6, 1999

Alburnus Maior III/1. Necropola romană de incinerație de la Tăul Corna, P. Damian (coordonator), Cluj-Napoca, 2008

D. Alicu, Die firmalampen von Ulpia Traiana Sarmizegetusa, Dacia N.S, XX, 1976, p. 205-220

D. Alicu, Römische Tonlampen aus Sarmizegetusa (Ausgrabungskampagne 1976), Studii și comunicării, Caransebeș 1979, p. 235-252

D. Alicu, Precizări privind cronologia unor lămpi ştampilate de la Sarmizegetusa, Apulum, XXII, 1985, p. 77-87

D. Alicu, Opaiţele romane/Die Römischen Lampen. Ulpia Traiana Sarmizegetusa, București, 1994

D. Alicu, Die römischen Lampen von Sarmizegetusa. I. Die Funde der Jahre 1882-1876. 2 Ergänzte Ausgabe, Bibliotheca Musei Porolissensis VI, Zalău 2006

Eva Alram-Stern, Die Römischen Lampen aus Carnuntum, Der Römischen Limes in Österreich, Heft 35, Wien, 1989

M. J. Ackner, F. Müller, Die Römischen Inschriften in Dacien, Viena, 1865

Antique Bronzes in Romania, Exhibition Catalogue, L Petculescu (ed.), București, 2003

C. L. Băluţă, Opaiţele romane de la Apulum (I), Apulum, 4, 1961, p. 189-220

C. L. Băluţă, Opaiţele romane de la Apulum (II), Apulum, 5, 1965, p. 277295

C. L. Băluţă, Lămpile romane din Muzeul Județean Hunedoara-Deva. Sargetia, 13, 1977, p. 209-228

C. Băluţă. Lămpile romane de bronz din Dacia Superior, Sargetia, 14, 1979, p. $164-172$

C. L. Băluţă, Lucernele romane din Dacia intracarpatică, Cluj-Napoca, 1983 (teză de doctorat)

C. L. Băluţă, Lămpile antice de la Muzeul de Istorie Sibiu, Apulum, XXVI, 1989, p. 237-262

C. L. Băluţă, Lămpile romane din Muzeul Naţional de Istorie a Transilvaniei. ActaMN, 33/I, 1996, p. 89-113

C. L. Băluţă, Lămpi cu marcă epigrafică inedite. Descoperite la Apulum Partoș. Apulum, XXXVI, 1999, p. 225-240

C. L. Băluţă, Lămpile antice de la Alba Iulia (Apulum). I Lămpile Epigrafice, Bucureşti, 2003

Al. Bărcăcilă, Noui monumente funerare din Drubeta, cu însemnarea descoperirilor anterioare, Arhivele Olteniei, nr. 61-62, 1932, p. 231-267

Al. Bărcăcilă, Orașul și Castrul roman Drubeta, Boabe de Grâu, II, 1934, 10 11, p. $445-480$

M. Bărbulescu, Ana Cătinaș, Inscripţii dintr-un templu de la Potaissa, Eph. Nap., 2, 1992, p. 111-124

M. Bărbulescu, Potaissa. Studiu Monografic, Turda, 1994

D. M. Bailey, A Catalogue of the Lamps in British Museum 2. Roman Lamps made in Italy, London, 1980

D. M. Bailey, A Catalogue of the Lamps in British Museum III. Roman Provincial Lamps, London, 1988 
Bajusz 1980

Beldiman 1989

Benea 1990

Benea 1996

Benea 2012

Blăjan 1989

Bocan, Ursuțiu, Cociș 2007-2008

Bocan, Ursuțiu, Cociș 2008

Bocan et alii 2010

Bocan, Neagu 2016

Bogdan-Cătăniciu 1974

Bondoc 2008

Bondoc 2012

Bruneau 1965

Buchi 1975

Bussière 2000

Cătinaș 1996

Cătinaș 1997

Cătinaș 2004

Casasola 1995

Chirilă et alii 1972

Chrzanovski, Zhuravlev 1998

Chrzanovski 2000

Chrzanovski 2011
I. Bajusz, Colecția de antichități a lui Téglás István din Turda, ActaMP, IV, 1980, 367-394

C. Beldiman, Piese epigrafice din estul Daciei romane, Apulum, XXVI, 1989, p. 263-271

Doina Benea, Lampes romaines de Tibiscum, Dacia N.S., XXXIV, 1990, p. 139-168

Doina Benea, Lampenproduktion in Tibiscum, în vol. Susanne ZabehlickyScheffengger 1996, p. 59-62

Doinea Benea, Die lokale Lampenproduktion in Dakien zwischen Kunst und Imitation, în vol. L. Chrzanovski (ed.), Le Luminaire antique Lychnological Acts 3 , Actes du $3^{\mathrm{e}}$ Congrès International d'études de d'ILA, Université d`Heildelberg, 21-26.IX.2009, Montagnac, 2012, p. 25-35

M. Blăjan, Contribuții la repertoriul arheologic al așezărilor rurale antice (secolele II-III e.n.) din Dacia romană, Apulum, XXVI, 1989, p. 283-333

I. Bocan, A. Ursutiu, S. Cocis, Opaitele stampilate din necropola romană de incinerație de la Tăul Corna. Consideraţii preliminare, $C A, X I V-X V$, p. 203221

I. Bocan, A. Ursuțiu, S. Cociș, Stamped Clay Oil Lamps from the Roman Cremation Necropolis of Tăul Cornei. Preliminary Considerations, în vol. Roman, Gudea 2008, p. 41-52

I. Bocan, Cătălina M. Neagu, E. Dumitraşcu, G. Bălan, Considerații preliminare asupra unei incinte funerare din necropola romană de incineraţie de la Tăul Găuri-Hop, CA, XVII, București, 2010, p. 71-104

I. Bocan, Cătălina M. Neagu, Roman lamps discovered in the fort at Micia (Vețel, Hunedoara county) from the National History Museum of Romania collections. Considerations concernig the stamped lamps, în vol. Susanne Biegert (ed.), Rei Cretariae Romanae Favtorvm Acta 44, Bonn, 2016, p. 537545 .

Ioana Bogdan-Cătăniciu, Cercetări în Castellum de la Rucăr, SCIVA, 25, 1974, 1, p. 277-288

D. Bondoc, Roman Lamps from Cioroiu Nou, Cioroiași commune, Dolj County, Romania, în vol. Roman, Gudea 2008, p. 53-57

D. Bondoc, Firmalampen found in the Roman Fort of Slăveni, Olt County, Romania, în vol. L. Chrzanovski (ed.), Le Luminaire antique Lychnological Acts 3 , Actes du $3^{\mathrm{e}}$ Congrès International d'études de d'ILA, Université d'Heildelberg, 21-26.IX.2009, Montagnac, 2012, p. 37-41

$\mathrm{Ph}$. Bruneau, Exploration archéologique de Délos. Les lampes, Paris, 1965

E. Buchi, Lucerne del Museo di Aquileia, vol. I. Lucerne romane con marchio di fabrica. Associatione Nazionale per Aquileia, Aquileia, 1975

J. Bussière, Lampes antiques d'Algérie, Monographies Instrumentum 16, Montagnac, 2000

Ana Cătinaș, Lampes à estampille de Potaissa, în vol. Susanne ZabehlickyScheffengger 1996, p. 63-69

Ana Cătinaș, Opaiţe din colecţia Téglás, în vol. M. Bărbulescu (ed.), Civilizaţia romană în Dacia, Cluj-Napoca, 1997, p. 172-214

Ana Cătinaș, Les importations céramiques de l'Ouest de L'Empire Romain a Potaissa et leur influence sur les ateliers locaux, în vol. Mariana Crânguș, Simona Regep-Vlascici, Atalia Ștefănescu (coordonatori), Studia Historica et Archeologica in Honorem Magistrae Doina Benea, Timișoara 2004, p. 83-97 D. B. Casasola, Las lucernas romanas del Museo Municipal de Ceuta, Ceuta, 1995

E. Chirilă, N. Gudea, V. Lucăcel, C. Pop, Castrul roman de la Bucium. Contribuţii la Cercetare Limesului Daciei Porolissensis, Cluj-Napoca, 1972

L. Chrzanovski, D. Zhuravlev, Lamps from Chersones in the State Historical Museum-Moscow, Roma, 1998

L. Chrzanovski, Lumieres antiques. Les lampes à huile du Musée Romain de Nyon, Milano, 2000

L. Chrzanovski, Les lampes romaines rectangulaire à plusieurs becs, entre Egypte et Dacie: Quelques éléments de discussion issu de l'étude d'une collection alexandrine inédite, Peuce S.N, IX, 2011, p. 217-224 
Curk 1976

Cristescu 2004

Cserni 1912

Daicoviciu 1924

Daicoviciu 1930-1931

Daicoviciu, Floca 1937

Egri 2005

Floca, Valea 1965

Floca, Ferenczi, Mărghitan 1970

Floca, Mărghitan 1970

Florescu 1933

Gaiu 2010

Gostar 1961

Gudea 1973

Gudea 1977

Gudea 1989

Gudea 1996

Gudea, Cosma 2008

Gherghe, Negru 2008

Gherghe, Cojoc 2011

Hamat, Georgescu 2013

Hayes 1980

Heimerl 2001

Höpken, Fiedler 2008

Iconomu 1967

Isac 1997

Isac 2003

Isac, Roman 2001

Isac, Roman 2008
Iva Mikl Curk, Poetovio I, Ljubljana, 1976

V. Cristescu, Viața economică a Daciei Romane, București, 2004

B. Cserni, Jelentés a Colonia Apulensis területén végzett ásatásokról, Múzeumi és Könyvtári Értesitö, 1912, 15/4, p. 257-283

C-tin. Daicoviciu, Fouilles et recherches a Sarmizegetusa, Dacia, 1, 1924, p. 224-263

C. Daicoviciu, Micia I. Cercetări asupra castrului, Anuarul Comisiunii Monumentelor Istorice. Secția pentru Transilvania, 1930-1931, p. 1-43

C. Daicoviciu, O. Floca, Mausoleul Aureliilor de la Sarmizegetusa. Raport preliminar, Sargetia, 1, 1937, p. 1-23

Mariana Egri, Roman Lamps from Liber Pater Sanctuary (Alba-Iulia, Romana), în vol. L. Chrzanovski (ed.), Lychnological Acts 1. Actes du $1^{\text {er }}$ Congrès international d'etudes sur le luminaire antique (Nyon-Genève, 29.IX-4.X. 2003), p. 85-87

O. Floca, M. Valea, „Villa rustica” şi necropola daco-romană de la Cinciş, ActaMN, 2, 1965, p. 163-192

O. Floca, Șt. Ferenczi, L. Mărghitan, Micia. Grupul de cuptoare romane pentru ars ceramica, Deva, 1970

O. Floca, L. Mărghitan Noi considerații privitoare la castru roman de la Micia, Sargetia, VII, 1970, p. 43-57

Gr. Florescu, Castrul roman Drobeta (T. Severin). Cercetări și săpături arheologice din 1931, Revista istorică-română, III, I, 1933, p. 32-53

C. Gaiu, Opaițele ceramice de la Arcobadara, Revista Bistriței, XXIV, 2010, p. 217-243

N. Gostar, Inscripţiile de pe lucernele din Dacia romană, ArhMold, I, 1961, 149-209

N. Gudea, O locuință rustică din epoca romană la Gornea, ActaMN, X, 1973, p. $569-593$

N. Gudea, Materiale arheologice din castrul roman de la Bologa, Apulum, XV, 1977, p. 169-215

N. Gudea, Porolissum. Un complex arheologic daco-roman la marginea de nord a Imperiului roman, I, ActaMP, XIII, 1989

N. Gudea, Porolissum. Un complex arheologic daco-roman la marginea de nord a Imperiului roman. II. Vama romană. Monografie arheologică. Contribuții la cunoașterea sistemului vamal din provinciile dacice, ClujNapoca, 1996

N. Cosma, C. Cosma, Die lampen aus dem Römerkastell von Buciumi (Dacia Porolissensis), în vol. Roman, Gudea 2008, p. 117-128

P. Gherghe, M. Negru, Frimalamen found in Sucidava Territory, în vol. Roman, Gudea 2008, p. 87-90

$\mathrm{P}$. Gherghe, M. Cojoc, Opaițele romane și romano-bizantine descoperite în teritoriul Sucidavei, Craiova, 2011

Ana Cristina Hamat, V. Șt. Georgescu, Considerații privind producția locală de opaițe de lut la Tibiscum, Tibiscum S. N., Caransebeș, III, 2013, p. 223-244

J. W. Hayes, Ancient Lamps in the Royal Ontario Museum, I. Greek and Roman Clay Lamps A Catalogue, Toronto, 1980

A. Heimerl, Die römischen Lampen aus Pergamon, Pergamenische Forschungen 13, Deutsches Archäologische Institut, Berlin-New York, 2001

Constantze Höpken, M. Fiedler, Römischen lampen aus dem Domnus und Domna-Heiligtum in Ulpia Traiana Samizegetusa/Dacia, în vol. Roman, Gudea 2008, p. 145-151

C. Iconomu, Opaiţe greco-romane, Constanța, 1967

D. Isac, Castrele de cohortă și ală de la Gilău, Zalău, 1997

D. Isac, Castrul roman de la Samum-Cășeiu, Cluj-Napoca, 2003

D. Isac, C. A. Roman, Lucernele din castrul de Gilău, în vol. C. Cosma, D. Tamba, A. Rustoiu (ed.), Studia Archaeologica et Historica Nicolao Gudea dicata. Omagiu profesorului Nicolae Gudea la 60 de ani, Cluj-Napoca, 2001, p. 367-395

D. Isac, C. A. Roman, Roman Lamps from SAMVM (Cășeiu, Cluj County), în vol. Roman, Gudea 2008, p. 153-154 
Iványi 1935

Krunić 2005

Kuzmanov 1992

Labate 2013

Leibundgut 1977

Lychnus et Lampas 2006

Lipovan 1982-1983

Lipovan 1983-1984

Lipovan 1988

Loeschcke 1919

Man 2011

Marinescu et alii 1979

Matei, Bajusz 1997

Matei et alii 2006

Menzel 1954

Mitrofan 1964

Mitrofan 1969

Moga et alii 2003

Moțu 1991

Munsell 1994

Mușețeanu, Elefterescu 1983

Neagu, Bocan 2007-2008

Negru 1996

Negru, Bădescu 2005

Negru, Bădescu, Avram 2008

Neigebaur 1851

Petculescu, Nemoianu, Anastasiu 1981

Paraschiv, Nuțu 2012
Dora Iványi, Die pannonischen Lampen. Eine Typologisch Chronologische Übersicht, Dissertationes Pannonicae, Series. 2, no. 2, Budapest, 1935

S. Krunić, Pregled Antičkih Svetiljki Singidunuma (Roman Lamps from Singidunum), Singidunum, 4, 2005, p. 45-104

G. Kuzmanov, Antike Lampen, Sofia, 1992

D. Labate, Gli impianti produttivi della collina modenese in età romana: note sulla produzione di ceramic e di Lucerne, Quaderni di Archeologia dell' Emilia Romagna, 2013, 31, p. 33-40

Annalis Leibundgut, Die Römischen Lampen in der Schweiz, Bern, 1977

Lychnus et Lampas. Exhibition Catalogue, A. Isac, C. A. Roman (ed.), ClujNapoca, 2006

I. T. Lipovan, Opaițe romane din Ampelum (I), Sargetia, XVI-XVII, 19821983, p. 227-232

I. T. Lipovan, Officina ceramistului Gaius Iulius Proclus la Ampelum. AIIACluj, XXVI, 1983-1984, p. 301-317

I. T. Lipovan, Opaițe romane din Ampelum (II), Tibiscum, Caransebeș, VII, 1988, p. 181-188

S. Loeschcke, Lampen aus Vindonissa. Ein Beitragezur Geschichtevon Vindonissaund des antiken Beleuchtungswesens, Zürich, 1919

Nicoleta Man, Așezarea romană de la Cristești, Cluj-Napoca, 2011

Lucia Marinescu, Anișoara Sion, L Petculescu, I. Andrițoiu, Edith Ionescu Rusu, Maria Bărileanu, Șantierul Arheologic Micia (Vețel, jud. Hunedoara), CA, III, 1979, p. 105-126

A. V. Matei, I. Bajusz, Das Römergrenzkastell von Romita-Certiae, Zalău, 1997

A. V. Matei, H. Pop, Elena Muscă, E. Pripon, I. Bejinariu, Instrumente de iluminat din nord-vestul României, Catalog expoziție, Zalău, 2006

H. Menze, Antike Lampen im Römisch-Germanischen Zentralmuseum zu Mainz, Mainz, 1954

I. Mitrofan, Contribuții la cunoașterea orașului Napoca, ActaMN, 1964, I, p. 197-213

I. Mitrofan, Descoperiri arheologice la Potaissa (Turda), ActaMN, VI, 1969, p. $517-523$

V. Moga, C. Inel, A. Gligor, A. Dragotă, Necropola de incineratie din punctul Hop, în vol. P. Damian (ed.), Alburnus Maior I, 2003, București, p. 193-251

I. Moțu, Așezare rurarlă romană de la Aiton (jud. Cluj), ActaMP, XIV-XV, 1991, p 175-219

A. H. Munsell, Soil color charts, 1994

C. Mușețeanu, D. Elefterescu, Lampes romaines de Durostorum, Dacia N.S., XXVII, 1-2, 1983, p. 109-128

Cătălina M. Neagu, I. Bocan, Considerații preliminare asupra unei incinte funerare din necropola romană de incineraței de la Tăul Secuilor - Pârâul Porcului, Alburnus Maior, CA, XIV-XV, București, 2007-2008, p. 93-122

M. Negru, Some Aspects of the Lamps Discovered in the Roman Forts of Muntenia, în vol. Zabehlicky-Scheffengger 1996, p. 75-80

M. Negru, Al. Bădescu, Roman Lamps discovered in Romula, în vol. L. Chrzanovski (ed.), Lychnological Acts 1. Actes du $1^{\text {er }}$ Congrès international d'etudes sur le luminaire antique (Nyon-Genève, 29.IX-4.X. 2003), p. 253255

M. Negru, Al. Bădescu, R. Avram, Roman Lamps discovered in Romula, în vol. Roman, Gudea 2008, p. 191-195

J. F. Neigebaur, Dacien. Aus den Üeberresten des klassischen Alterthums mit besonderem Rücksicht auf Siebenbürgen, Kronstadt, 1851

L. Petculescu, A. T. Nemoianu, Ruxandra Anastasiu, Raport preliminar asupra săpăturilor arheologice din 1978-1979 în castru Micia, com. Vețel jud. Hunedoara, CA, IV, 1981, p. 70-75

D. Paraschiv, G. Nuț, Roman Lamp from Poșta (Moesia Inferior), în vol. L. Chrzanovski (ed.), Le Luminaire antique Lychnological Acts 3, Actes du $3^{e}$ 
Petrie 1905

Pop 1970

Popilian 1971

Protase 1974

Protase, Gudea, Ardevan 2008

Regep 2001

Regep-Vlascici, Muscalu 2007

Rodriguez Martin 2005

Roman 2005

Roman 2006

Roman, Gudea 2008

Russu 1962

Simion, Apostol, Vleja 2004

Simion et alii 2007-2008

Szentléleky 1969

Thévenot,

Fromageot-Girardet 1948

Tocilescu 1902

Topoleanu 2010

Topoleanu 2012

Torma 1870

Tudor 1937

Tudor 1968

Tudor 1978

Zabehlicky-Scheffengger 1996

Zăgreanu 2011

Walters 1914
Congrès International d'études de d'ILA, Université d'Heildelberg, 2126.IX.2009, Montagnac, 2012, p. 287-294

W. M. F. Petrie, Roman Ehnasya (Hreakleopolis Magna 1904), London, 1905

C. Pop, Reprezentări bacchice romane în Transilvania, ActaMN, VII 1970, p. 151-161

Gh. Popilian, Thermele de la Slăveni, Apulum IX, 1971, p. 626-641

D. Protase, Necropola oraşului Apulum. Săpăturile din anii 1970-1971, Apulum, XII, 1974, p. 134-159

D. Protase, N. Gudea, R. Ardevan, Din istoria militară a Daciei Romane. Castrul Roman de Interior de la Gherla, Timişoara, 2008

Simona Regep, Noi descoperiri de opaițe de tip Firmalampen la Tibiscum, în vol. Doinea Benea (ed.), In Memoriam Dumitru Tudor, Timişoara, 2001, p. 81-90

Simona Regep-Vlascici, B. Muscalu, Opaițele dreptunghiulare cu ansa în formă de vultur descoperite la Tibiscum, în vol. Doinea Benea (ed.), Meșteșugari și artizani în Dacia romană, Timișoara, 2007, p. 132-142

F. G. Rodríguez Martín, Lucernas Antigüdades Romanas 2, în vol. Real Academia de la Historia Catálogo Del Gabinete de Antigüdades 2. 2.2, Madrid, 2005

C. A. Roman, Piese de iluminat în epoca romana Dacia Porolissesnsis, ClujNapoca, 2005 (teză de doctorat, manuscris)

C. A. Roman, Lamps from Dacia Porolissensis. The Roman Forts from Porolissum-Moigrad, Buciumi, Gilău, Samum-Cășei, Zalău, 2006

C. A. Roman, N. Gudea (ed.), Lychnological Acts 2, Trade and Local Production Lamps from the Prehistory until the Middle Age. Acts of $2^{\text {nd }}$ International Congress on Ancient and Middle Age Lighting Devices, ZalăuCluj-Napoca $13^{\text {th }}-18^{\text {th }}$ 2006, Cluj-Napoca, 2008

I. I. Russu (recenzie) N. Gostar, Inscripţiile de pe lucernele din Dacia romană, $S C I V$, XIII, 2, 1962, p. 467-471

Mihaela Simion, V. Apostol, D. Vleja, Alburnus Maior II. Monumentul funerar circular, București, 2004

Mihaela Simion, I. Bocan, D. Vleja, E. Dumitraşcu, „Atelierul” de procesare a minereului aurifer și necropola romană de incinerație de la Jig Piciorag, Roșia Montană, CA, XIV-XV, 2007-2008, p. 123-165

T. Szentléleky, Ancient Lamps, Budapest, 1969

E. Thévenot, J. Fromageot-Girardet, La station antique des Bolards à NuitsSaint-Georges (Côted'Or), Gallia, 6/2, 1948, p. 289-347

Gr. Tocilescu, Monumentele epigrafice și sculpturali ale Museului Național de Antichități din Bucuresci, București, 1902

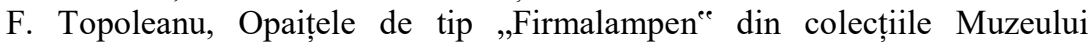
Județean de Istorie și Arheologie Prahova, ArhMold, XXXIII, 2010, p. 151188

F. Topoleanu, Lămpile antice din colecțiile Muzeului Județean de Istorie și Arheologie Prahova - Ploiești, Ploiești, 2012

$\mathrm{K}$. Torma, A szombathelyi római mécsesen levő cursiv-irás megfejtése, Archaeologiai Értesitö, 1870, II, p. 305-306

D. Tudor, Monumente inedite din Romula, Buletinul Comisiunii Monumentelor Istorice, XXX, 1937, p. 110-124

D. Tudor, Oltenia romană, ediția a III-a, București, 1968

D. Tudor, Oltenia romană, ediția a IV-a, București, 1978

Susanne Zabehlicky-Scheffengger (ed.), Rei Cretariae Romanae Favtorvm. Acta 33. Congressvs Vndevicesimvs Rei Cretariae Romanae Favtorvm in Dacia Habitvs, MCMXCIV, Abingdon, 1996

R.I. Zăgreanu, Roman Lamps in the Collection of Székely National Museum, Acta Siculica, Anuarul Muzeului Naţional Secuiesc, Sfântul Gheorghe, 2011, p.169-176

H. B Walters, Catalogue of the Greek and Roman Lamps in the British Museum, London, 1914 


\section{LISTA ILUSTRATIEI}

Pl. I. 1: Plan general al castrului roman de la Micia (apud Floca, Mărghitan 1970 și Petculescu 1986; 2: Castul roman de la Micia, localizarea (detalii Google Earth).

PI. II. Castrul roman de la Micia. Dispunerea opaițelor cu ștampile (apud Petculescu 1986).

P. III. 1-17: Castrul roman de la Micia. Opaițe romane (fotografii).

PI. IV. 18-29: Castrul roman de la Micia. Opaițe romane (fotografii).

Pl. V: 30-43: Castrul roman de la Micia. Opaițe romane (fotografii).

Pl. VI. 44-71: Castrul roman de la Micia. Opaițe romane (fotografii).

Pl. VII. 72-94: Castrul roman de la Micia. Opaițe romane (fotografii).

PI. VIII. 95-11: Castrul roman de la Micia. Opaițe romane (fotografii).

Pl. IX 9. 1-15: Castrul roman de la Micia. Ștampile, detalii

Pl. X. 16-18: Castrul roman de la Micia. Ștampile, detalii

LIST OF ILLUSTRATION

PI I. 1: General plan of the Roman fort at Micia (apud Floca, Mărghitan 1970 and apud Petculescu 1986); 2: Roman fort at Micia. Geographic location (details from Google Earth).

PI II. Roman fort at Micia. Layout of stamped lamps (apud Petculescu 1986).

P. III. 1-17: Roman fort at Micia. Roman lamps (photos).

Pl. IV. 18-29: Roman fort at Micia. Roman lamps (photos).

PI. V: 30-43: Roman fort at Micia. Roman lamps (photos).

PI. VI. 44-71: Roman fort at Micia. Roman lamps (photos).

PI. VII. 72-94: Roman fort at Micia. Roman lamps (photos).

PI. VIII. 95-11: Roman fort at Micia. Roman lamps (photos).

Pl. IX 9. 1-15: Roman fort at Micia. Details of stamps.

Pl. X. 16-18. Roman fort at Micia. Details of stamps.

IONUȚ BOCAN, CĂTĂLINA-MIHAELA NEAGU, MUZEUL NAȚIONAL DE ISTORIE A ROMÂNIEI, ionutzbocan@gmail.com catalina_mihaela_n@yahoo.com 
alba 

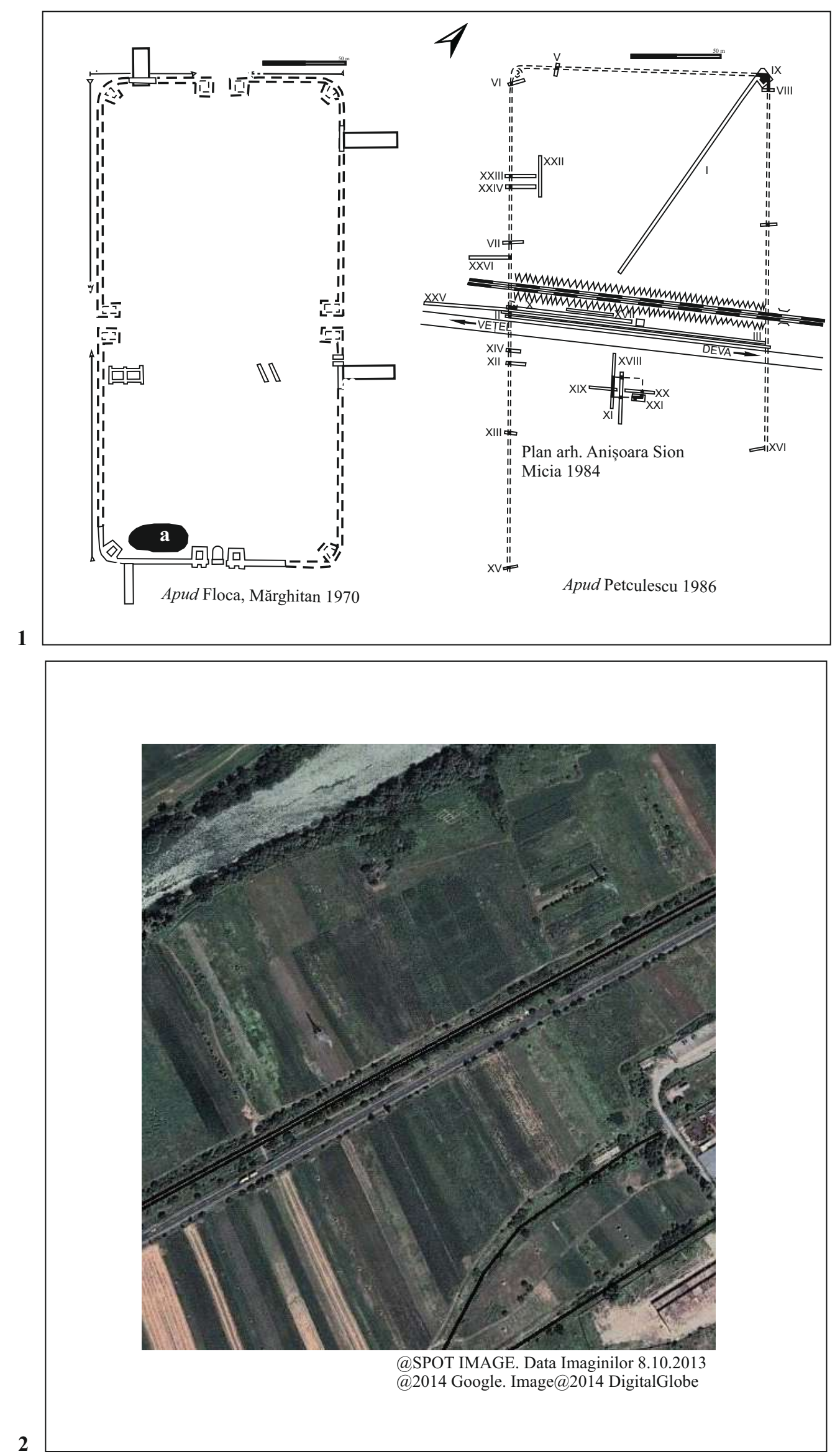


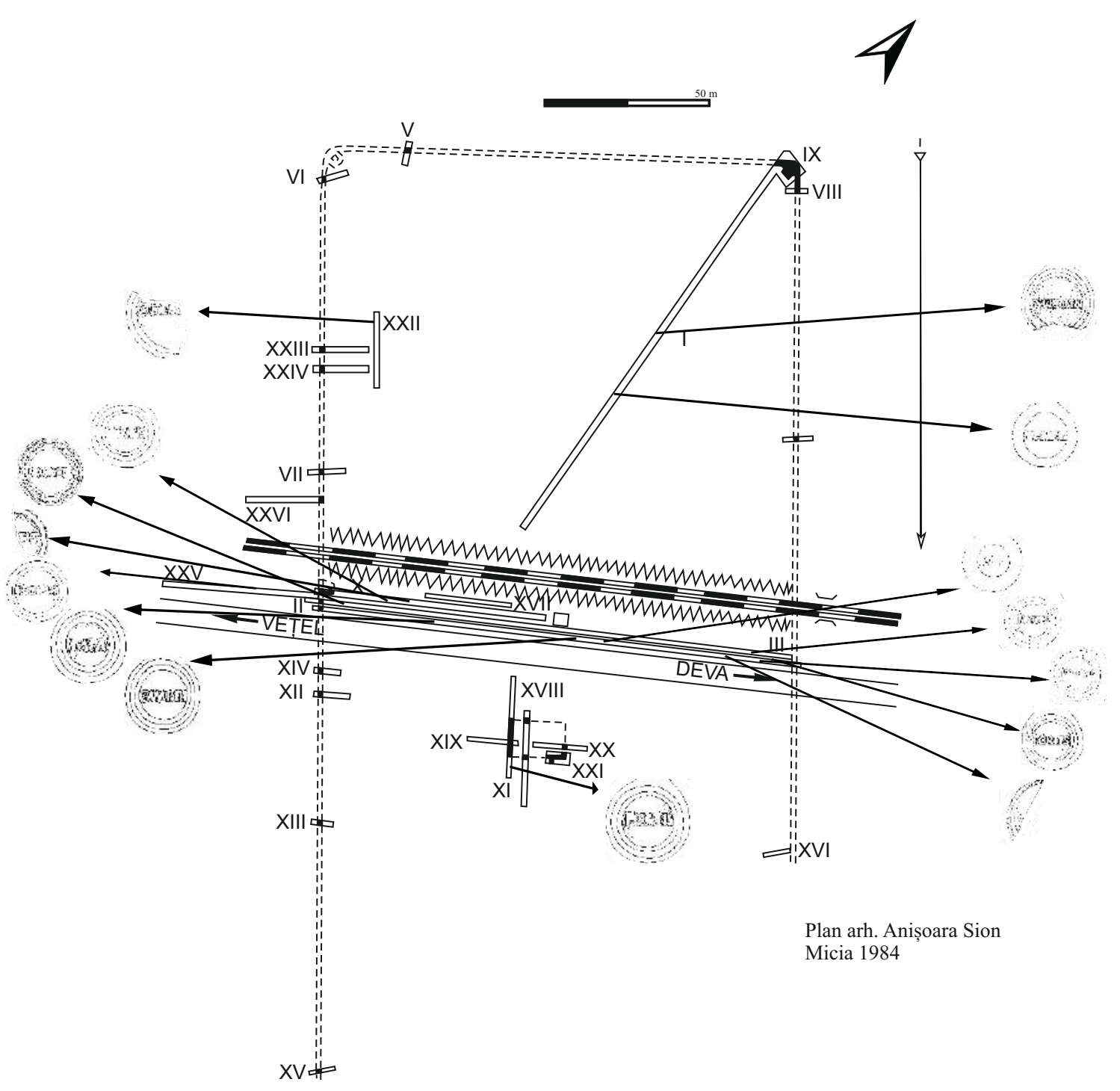

Apud Petculescu 1986 


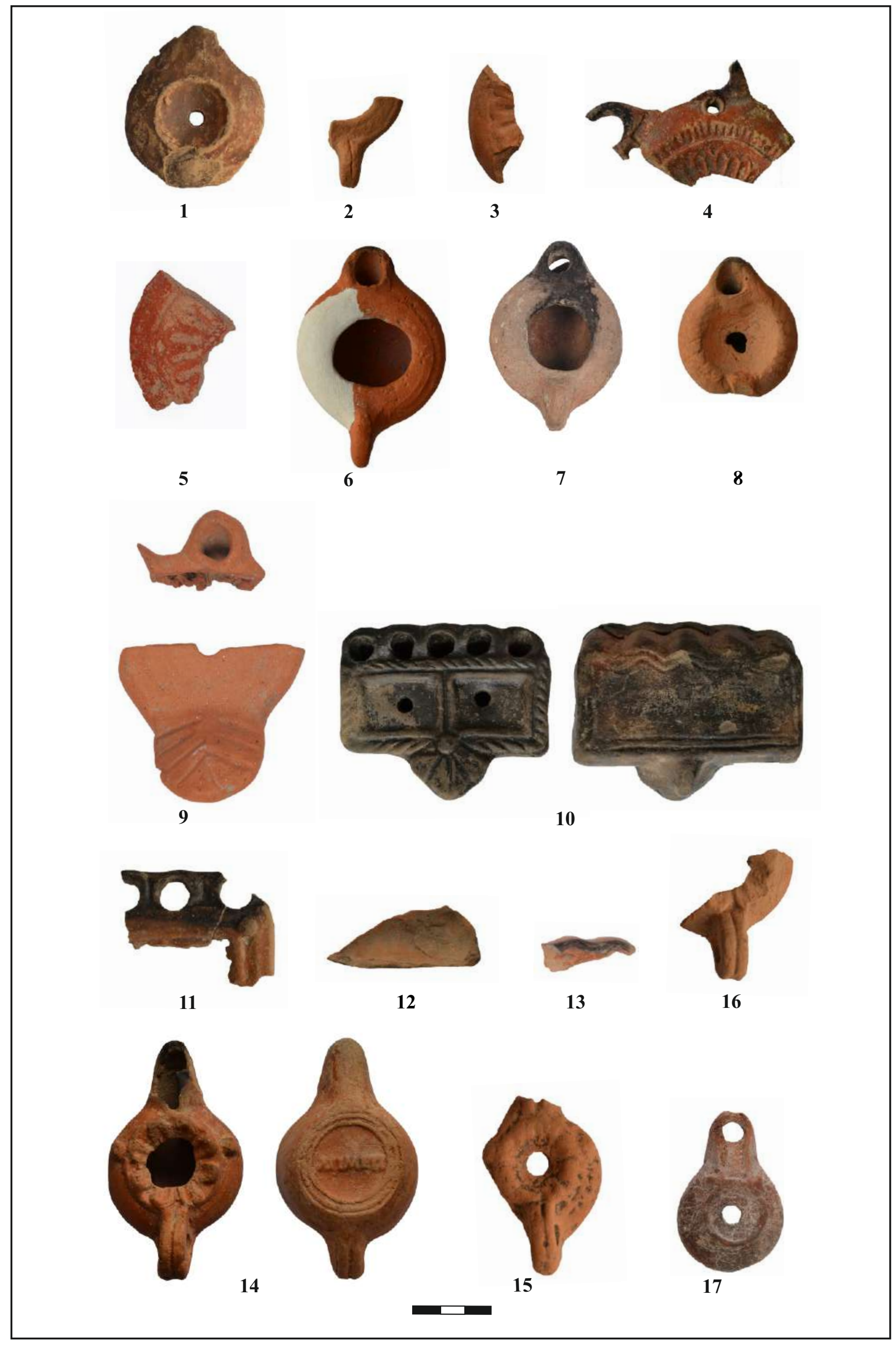

PI. III 

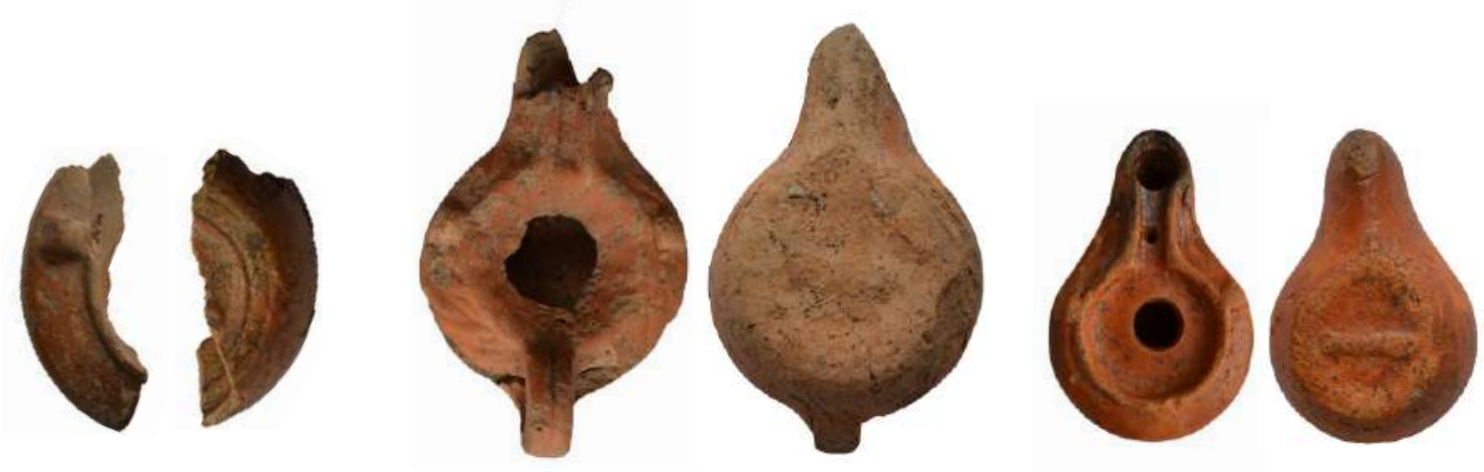

18

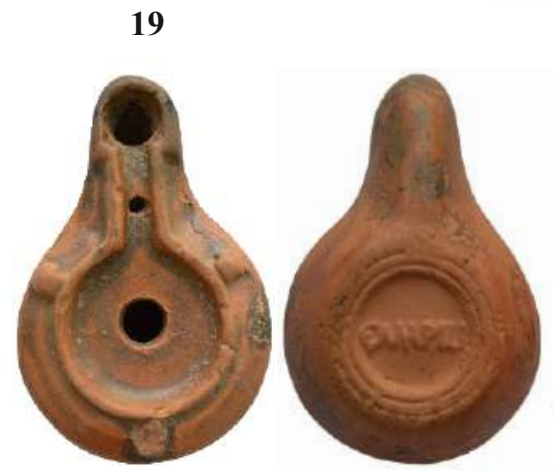

22

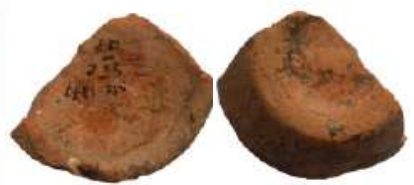

23

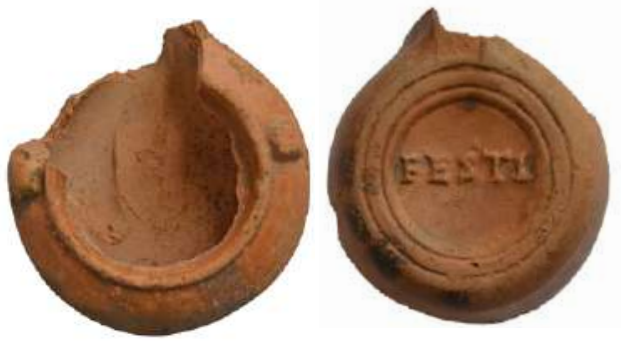

24

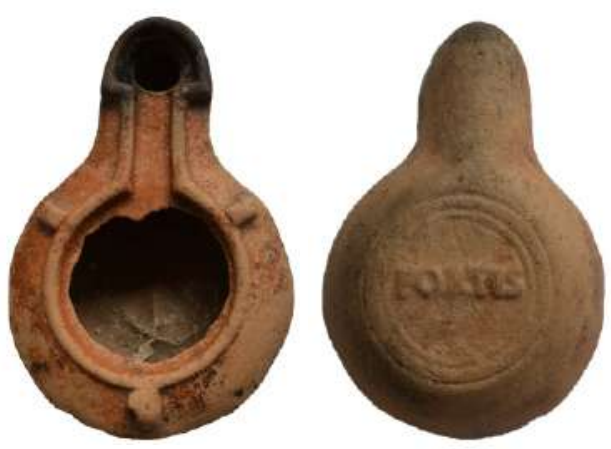

26

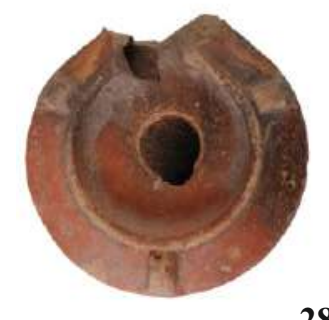

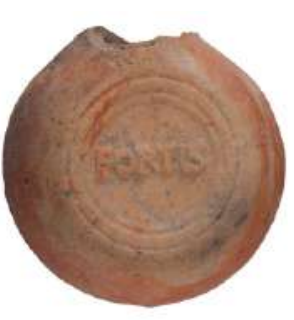

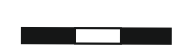

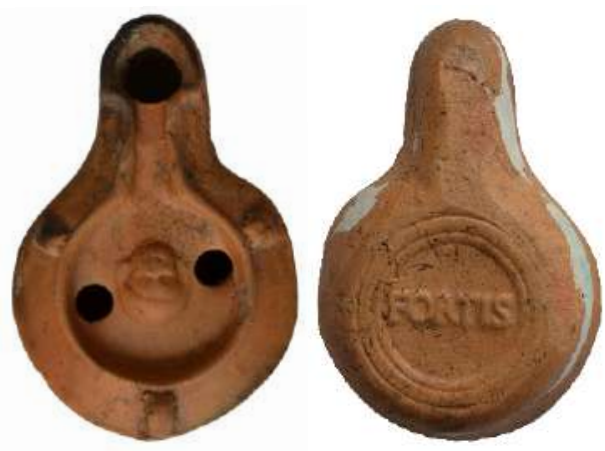

25

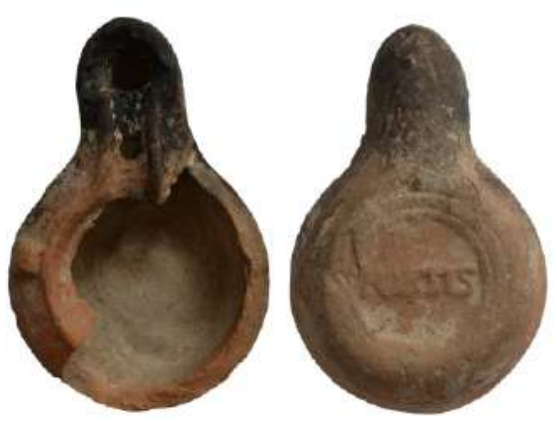

27

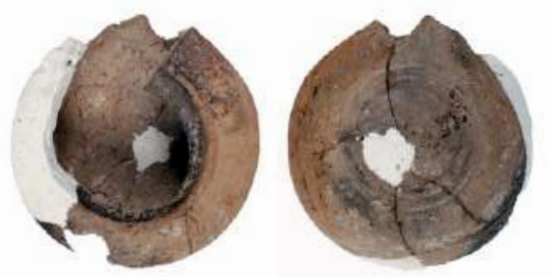

29

PI. IV 


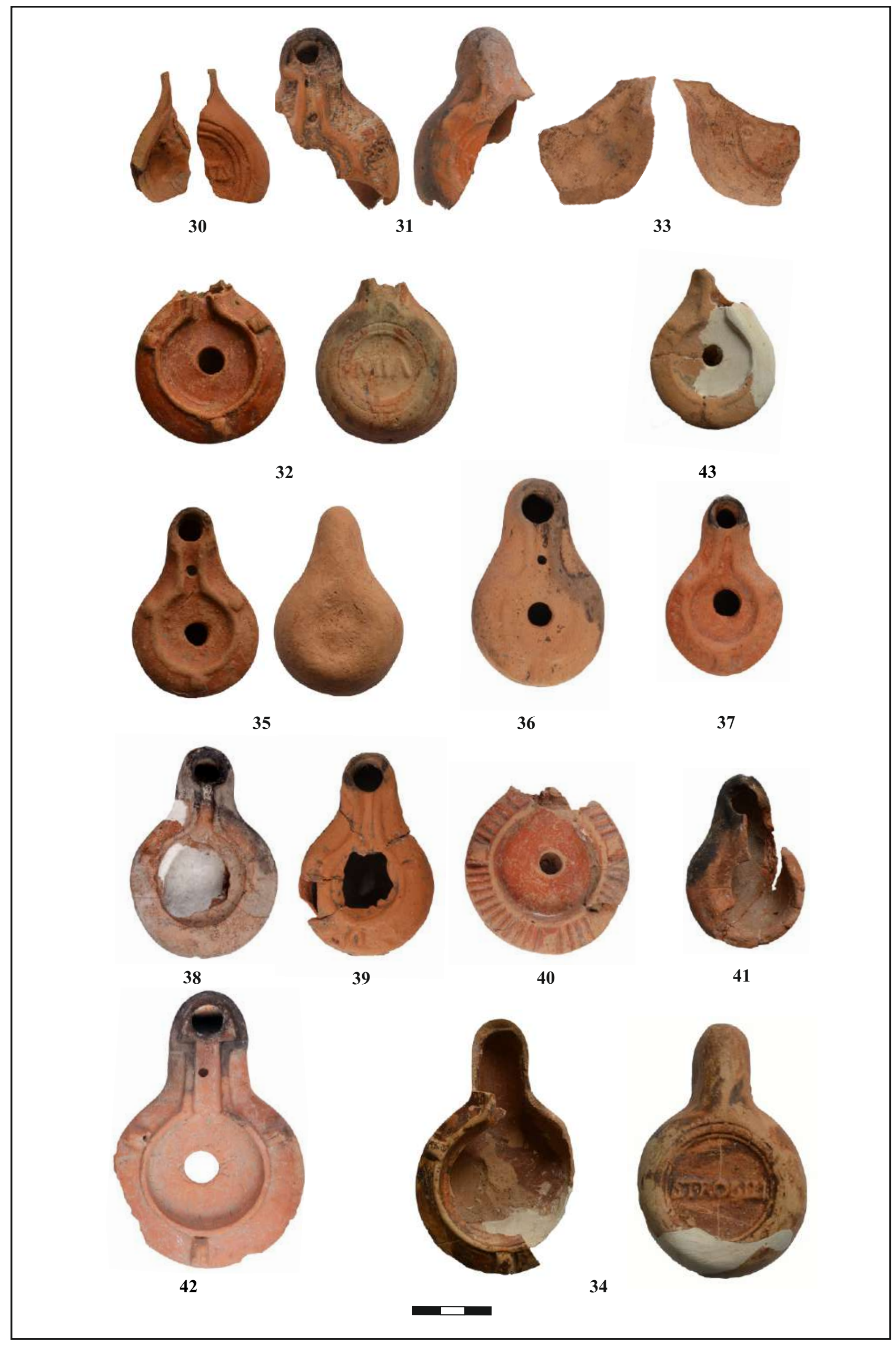

PI. V 


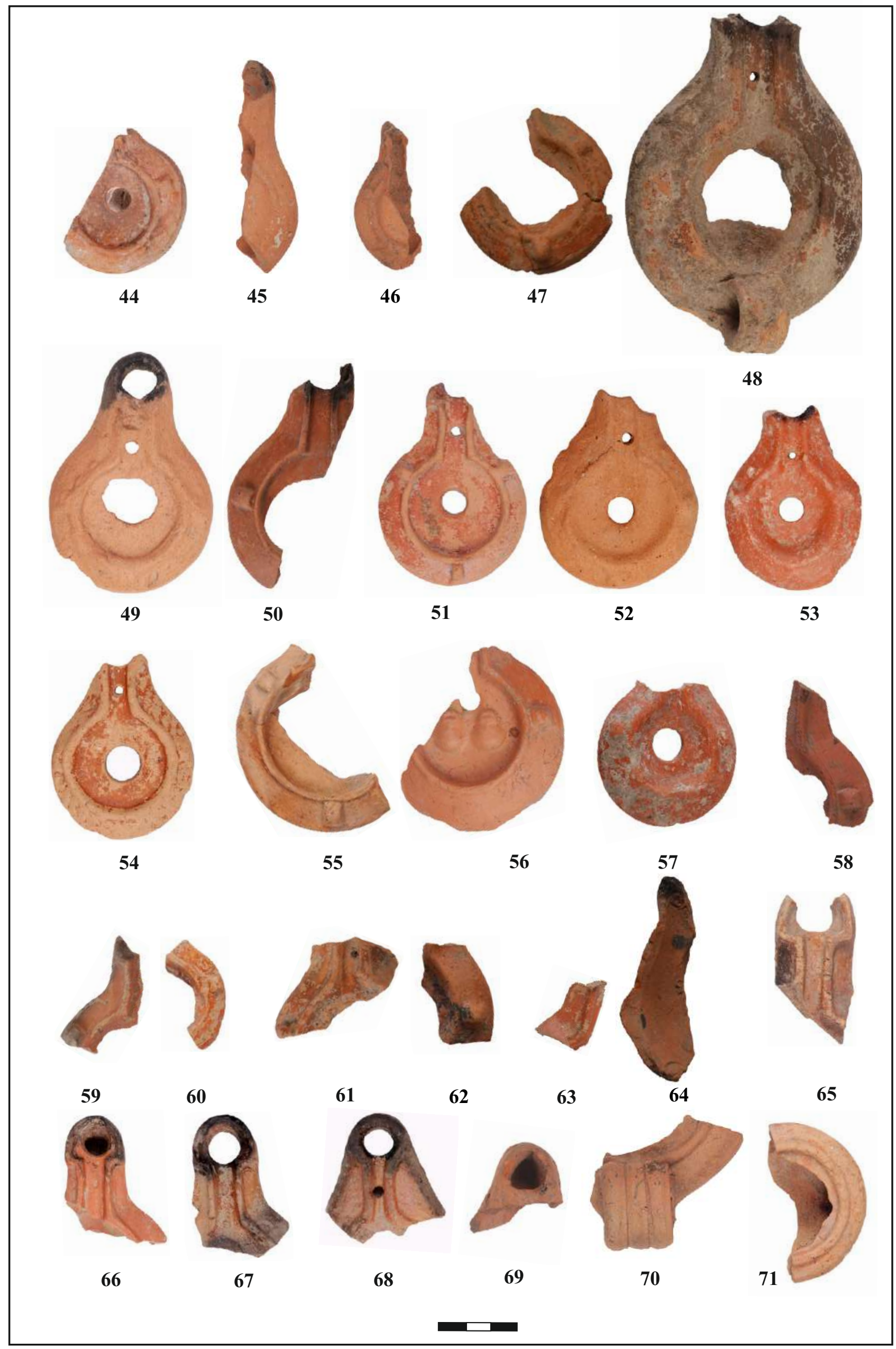

PI. VI 


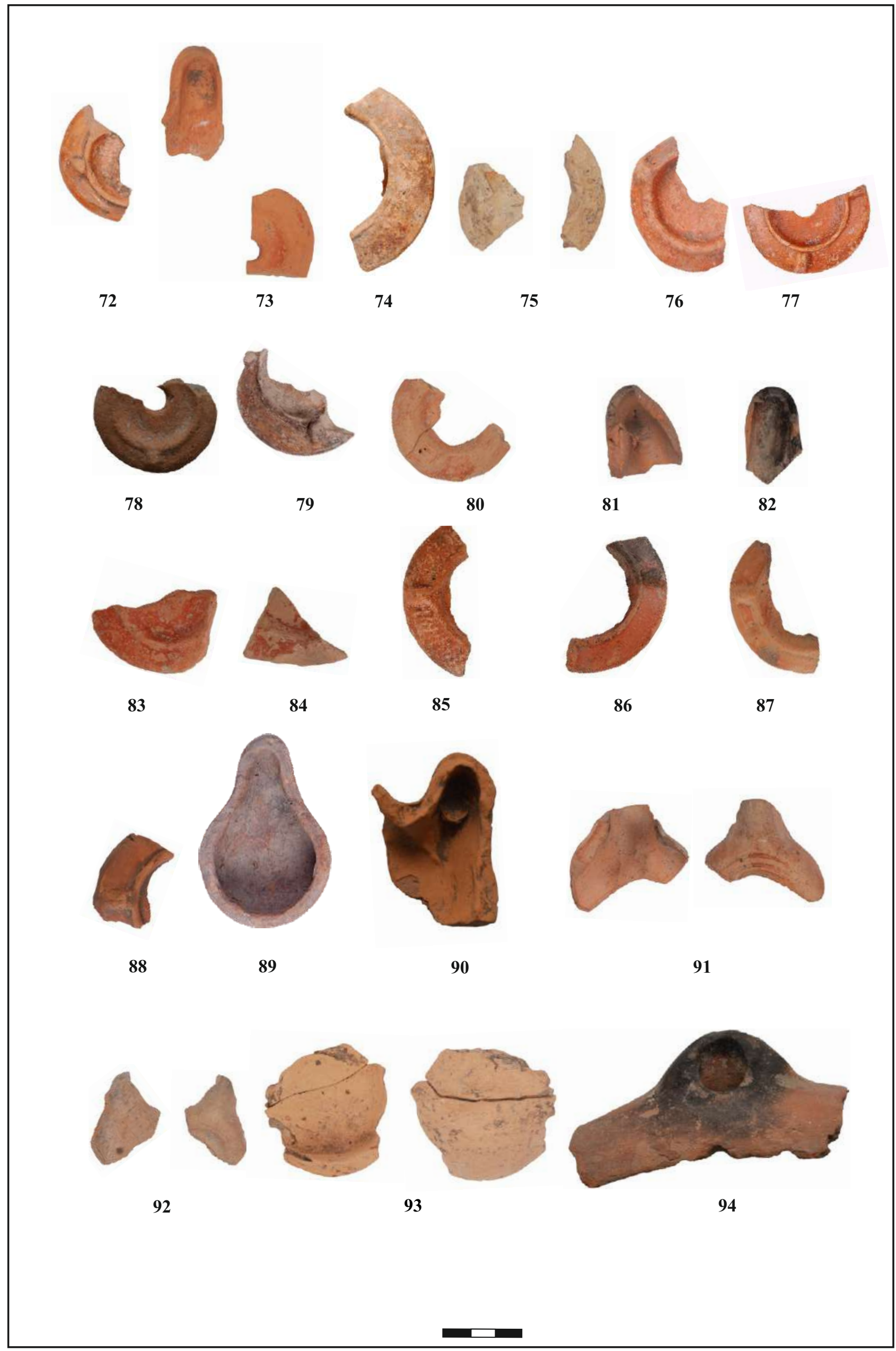

PI. VII 


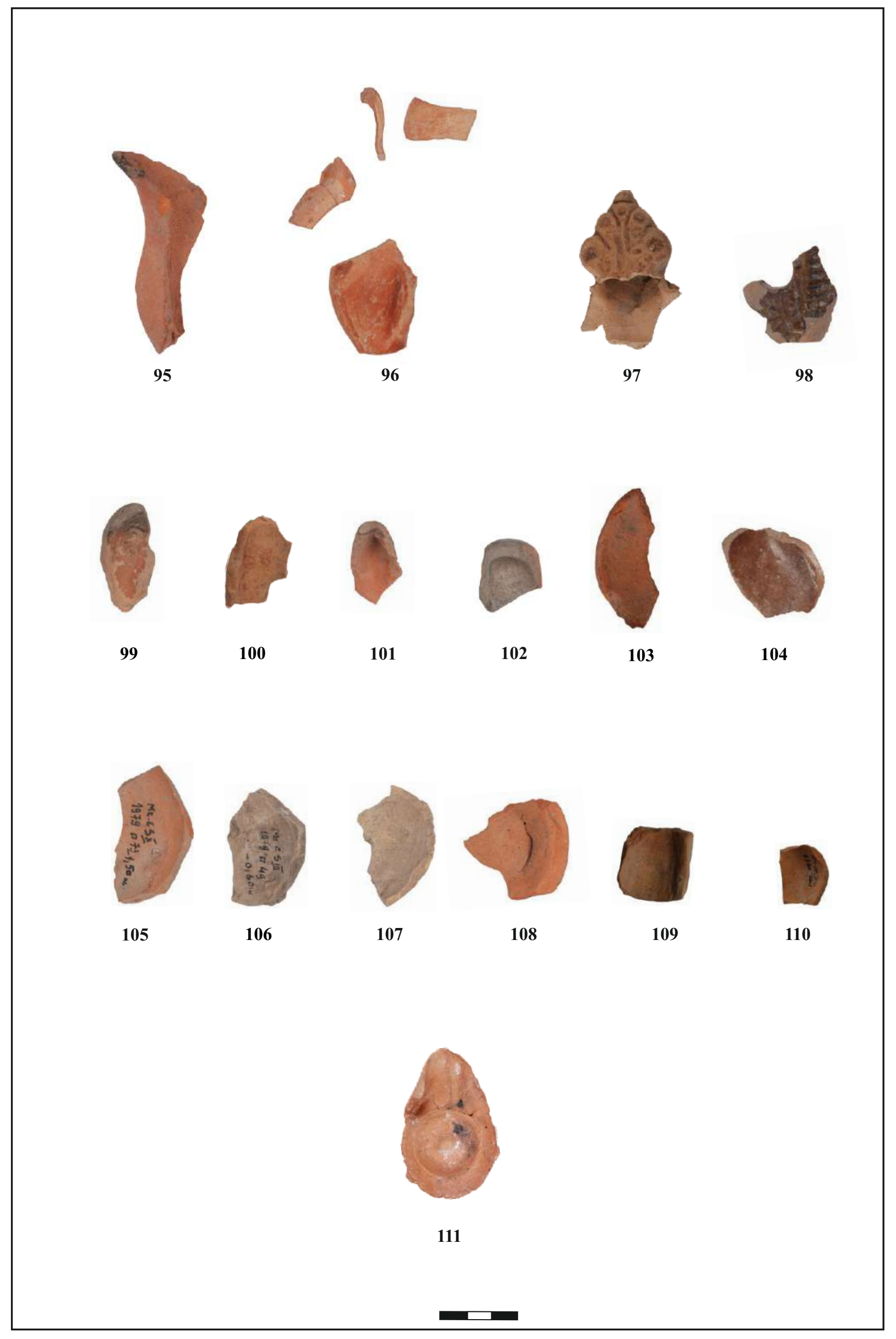

PI. VIII 

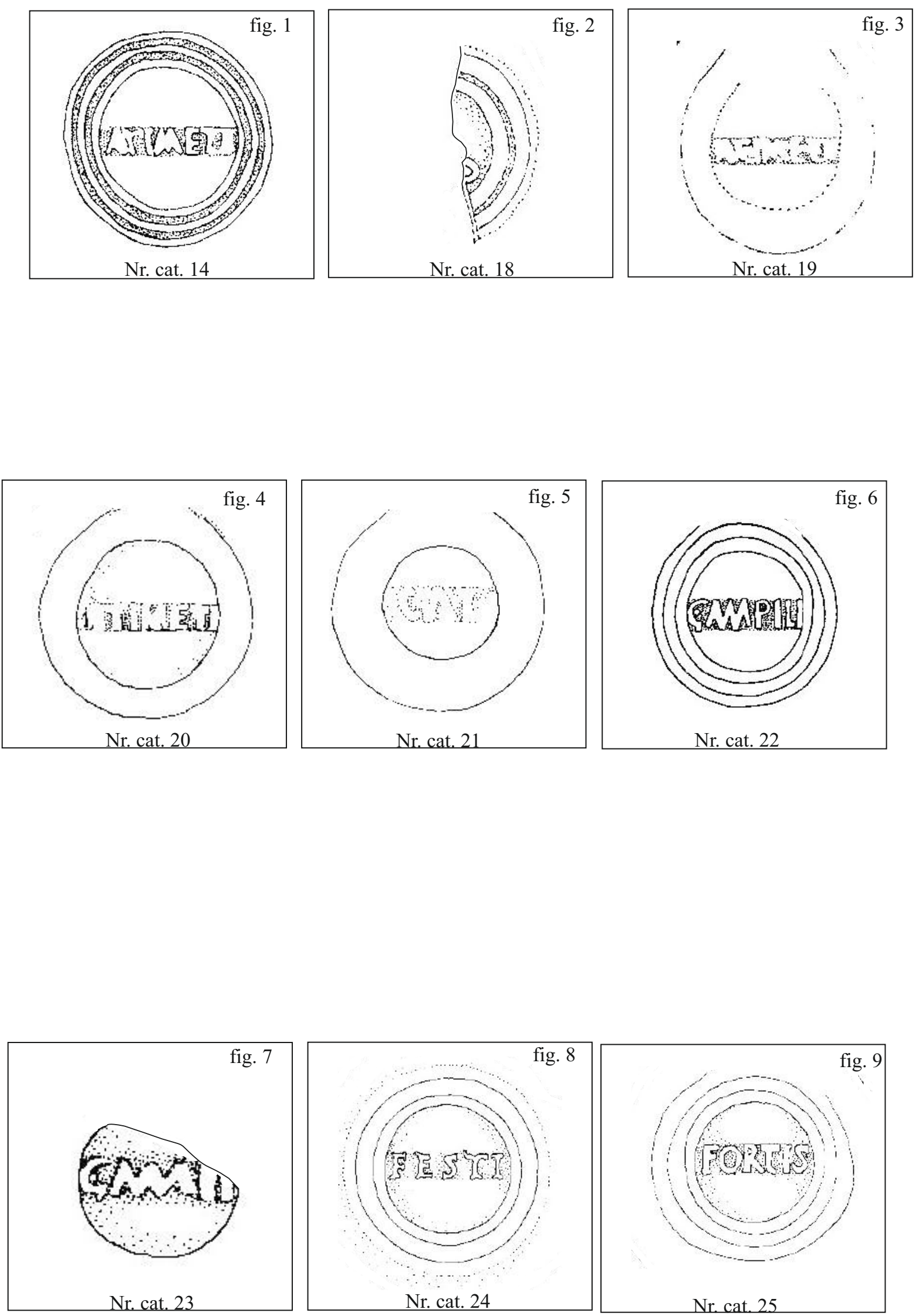

PI. IX 

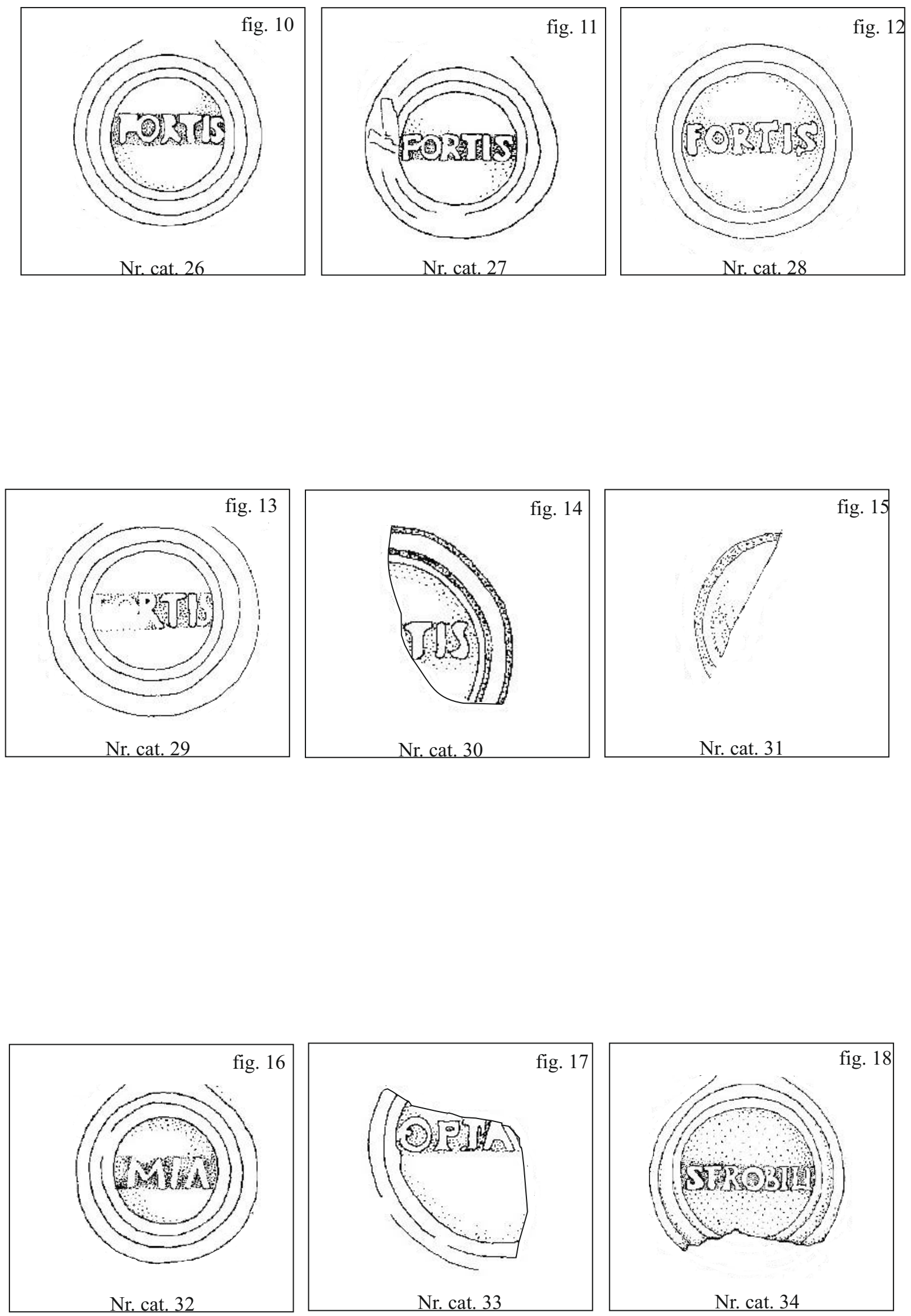

PI. X 